\author{
Universidade de São Paulo \\ Faculdade de Filosofia, Letras e Ciências Humanas \\ Departamento de Lingüística \\ Programa de Pós-Graduação em Semiótica e Lingüística Geral
}

\title{
O SENTIDO NAS CODIFICAÇÕES CIVIS BRASILEIRAS
}

Wallace Ricardo Magri

Dissertação apresentada ao Programa de Pós-Graduação em Lingüística e Semiótica do Departamento de Lingüística da Faculdade de Filosofia, Letras e Ciências Humanas da Universidade de São Paulo, para obtenção do título de Mestre em Letras.

Orientador: Prof Dr ${ }^{0}$ Antonio Vicente Seraphim Pietroforte 



\author{
Universidade de São Paulo \\ Faculdade de Filosofia, Letras e Ciências Humanas \\ Departamento de Lingüística \\ Programa de Pós-Graduação em Semiótica e Lingüística Geral
}

\title{
O SENTIDO NAS CODIFICAÇÕES CIVIS BRASILEIRAS
}

Wallace Ricardo Magri

Dissertação apresentada ao Programa de Pós-Graduação em Lingüística e Semiótica do Departamento de Lingüística da Faculdade de Filosofia, Letras e Ciências Humanas da Universidade de São Paulo, para obtenção do título de Mestre em Letras.

Orientador: Prof Dr ${ }^{0}$ Antonio Vicente Seraphim Pietroforte 
À minha mulher, Christina, pela paciência e amor dispensados. Ao meu filho, Matheus, por existir. 
Agradeço, primeiramente, ao professor orientador Antonio Vicente por ter tornado possível a realização desse projeto acadêmico, que me proporcionou tornar o sonho da docência uma realidade.

Não poderia deixar de agradecer aos meus pais, José e Marilda, pelo empenho e dedicação, sem os quais eu jamais poderia ter chegado até aqui e também ao meu irmão, Wagner, pela camaradagem permanente.

Agradeço também às professoras Norma Discini e Jeannete Antonios Maman que, cada uma a seu tempo, acreditaram em meu potencial e me incentivaram a desbravar novos horizontes do conhecimento. 


\section{RESUMO}

Toda vez que nova lei entra em vigor, surge na comunidade jurídica verdadeira avalanche de estudos, debates e discussões a respeito das possíveis mudanças que irá operar no ordenamento jurídico e, por conseqüência, na sociedade.

O ponto de partida dessa empreitada é debruçar-se sobre o texto legal em debate, procurando determinar o que ele busca comunicar por meio de artigos de lei, ou seja, interpretá-lo. Considerando que o objeto da semiótica é o sentido que se depreende de textos e considerando que a lei manifesta-se textualmente, nada está a impedir a aplicação da teoria semiótica como método de interpretação dos textos legais.

Lançando olhar semiótico em determinado texto jurídico, tomando-o como objeto e não como ponto de partida, é possível estudá-lo enquanto manifestação discursiva produtora de sentido, buscando em seus próprios elementos os efeitos de sentido que produz, as relações que estabelece com os demais textos jurídicos, o ethos que se forja na enunciação - instância produtora do sentido -, ou, como querem, "a vontade do legislador”, “o sentido da lei”.

Nas relações que os textos jurídicos estabelecem entre si, recriando-se mutuamente, dialogando de maneira explícita ou velada, encontra-se espaço para a aplicação das teorias de linha francesa de análise do discurso, que permitem, também dentro do campo de análise exclusivamente discursiva, analisar com profundidade as condições para produção de sentido, a instância da enunciação deslocada para o interdiscurso.

A entrada em vigor do Código Civil Brasileiro de 2002, revogando o Código Civil Brasileiro de 1916, dado à importância jurídica e social do tema e à sua atualidade, tornou óbvia a opção de tomar as codificações civis brasileiras como objeto de estudo, uma vez que abre a possibilidade de constatar a eficácia de tais modelos quando aplicados ao discurso jurídico e, ao mesmo tempo, propor um debate diferenciado sobre o tema, uma vez que afastado dos critérios mais comuns usados em direito para análise e interpretação das leis, que certamente abundarão nos demais estudos sobre a matéria. 
palavras - chave

semiótica jurídica

discurso jurídico

análise do discurso jurídico 


\begin{abstract}
Every time that new law is published, appears in the legal community true avalanche of studies, debates and quarrels regarding the possible changes that will go to operate in legal system and, for consequence, in the society.

The starting point of these studies is to lean over itself on the legal text in debate, being looked for to determine what it intends to communicate by means of law articles, or either, to interpret it. Considering that the object of the semiotics is the meaning through the analysis of texts and considering that the law is a text, nothing is to hinder the application of the semiotics theory as interpretation method for legal texts.
\end{abstract}

Launching a semiotic look at the legal texts, taking it as an object and not as starting point, it is possible to study it while discursive manifestation, searching in its proper elements the effect of felt that it produces, the relations that establish with other legal texts, the ethos that it forges in the articulation - producing instance of the direction -, or, as one says, "the will of the legislator", "the direction of the law".

In the relations that the legal texts establish between itself, recreating themselves mutually, dialoguing in explicit or guarded way, space is open for the application of the theories of French line of analysis of the speech, that allows, inside of the field of interspeech analysis to analyze with depth the conditions for direction production, the instance of the articulation dislocated for interspeech.

The publication of the Brazilian Civil Code of 2002, revoking the Brazilian Civil Code of 1916, due to the legal and social importance of the subject and to its present time, became obvious the option to take civil codifications of Brazil as study object, as far as opens the possibility to evidence the effectiveness of such models when applied to legal speech and, at the same time, to consider an alternative debate on the subject, as long as moved away from the used criteria most common in legal analysis and interpretation of the laws, that certainly will proliferate in abundance into the studies on the subject. 
key - words

legal semiotics

legal speech

analysis of legal speech 


\section{SUMÁRIO}

INTRODUÇÃO

CAPÍTULO I

CAPÍTULO II

CAPÍTULO III

CONCLUSÃO

BIBLIOGRAFIA

ANEXOS

I - DOS CONDOMÍNIOS EDILÍCIOS (CC DE 2002)

II - DO DIREITO DE FAMÍLIA - TÍTULOS I a III (CC DE 2002)

III - DO DIREITO DE FAMÍLIA - TÍTULOS I a VI (CC DE 1916) 


\section{INTRODUÇ̃̃O}

Muitas vezes, assistimos acompanhados a um filme, a uma peça de teatro, ou simplesmente ouvimos uma música ou assistimos a seriados de TV. É curioso notar que, quando se comenta sobre o que se assistiu ou se ouviu as opiniões podem ser variadas, contando cada um dos espectadores com uma percepção diversa de determinado texto, o que nos leva à seguinte indagação: será que o sentido não está no texto? Será que o texto é vazio de significação e que o enunciatário que o torna meio de depreensão de sentido?

Ou será que, nenhum nem outro, o texto é um todo de significação que dá "pistas" de suas possíveis leituras, as quais, por serem os discursos da ordem do social, deciframos de acordo com os conhecimentos partilhados em determinada sociedade? Será que as diferentes percepções decorrem das também diferentes relações que cada espectador estabelece com determinado texto? Indo além, será que as possibilidades de leitura de um texto são infinitas e não há limites para os leitores apreenderem seus possíveis significados?

Como acreditar que determinado texto, entendido aqui como manifestação discursiva produtora de sentido, possa ser compreendido de qualquer maneira e se apresentar de modo absolutamente diferente para cada enunciatário? Fosse assim, seria praticamente impossível catalogar os filmes em uma vídeo-locadora, por exemplo, entre os temas de ação, suspense, terror, comédia, romance, infantil, etc.

E sabemos que é assim que eles se encontram identificados e é por esses critérios que os procuramos. Pode haver um pouco de romance em um filme de terror ou um pouco de terror em um filme de romance, mas mesmo assim podemos facilmente diferenciar uns dos outros. 
De fato, é possível examinar qualquer texto com base nas relações que seus termos estabelecem uns com os outros, de acordo com as opções de seleção e de combinação levadas a termo pelo enunciador, por meio das quais busca conferir sentido a seu discurso.

Tome-se como exemplo um filme, como o documentário "Bowling Columbine" ("Tiros em Columbine"), em que a recorrência de cenas de violência, o relato desesperado das vítimas sobreviventes do atentado sofrido naquela cidade, a abordagem "jornalística" do comércio de armas nos Estados Unidos da América e o interesse da indústria do aço norte-americana nesse comércio, leva forçosamente à leitura de uma crítica contra a venda livre e indiscriminada de armas, colocando a sociedade e a política norte-americana como responsáveis por aquela e tantas outras tragédias.

Um outro documentário poderia optar, por exemplo, por mostrar cenas de "bons americanos" satisfeitos com a possibilidade de realizar sua autodefesa, relatando a ameaça terrorista e a necessidade de cada cidadão norte-americano ser um "soldado" contra o terrorismo, incentivando a compra de armas por todos.

Mais do que isso, esse hipotético documentário poderia exaltar a personalidade e a vida dos garotos que cometeram os múltiplos atentados em Columbine e defini-los como jovens alienados por filmes, vídeos-game e músicas de cunho violento e que por essa razão cometeram essas atrocidades, que as armas são apenas mais uma "vítima" desses jovens desviados da sociedade.

Nota-se aqui que, em ambos os casos, os discursos giraram em torno do comércio de armas, respeitaram certos critérios comuns de produção de sentido, o que mudou foi a forma de seleção e combinação das formas possíveis de produção de sentido.

Aquele que possui postura ideológica contrária ao comércio de armas escolheu dentre os termos possíveis aqueles que enfatizam a nocividade de uma sociedade armada ao passo que aquele que é favorável ao comércio armamentista recorreu aos termos que melhor expressam sua ideologia. 
Observamos diferentes estratégias discursivas, visando a persuadir o enunciatário a aceitar seu ponto de vista como o mais adequado. $\mathrm{O}$ enunciatário, por sua vez, longe de ser mero receptor desses discursos vai com eles interagir e interpretá-los, aceitando-os ou refutando-os. E isso só é possível porque há um ponto invariável que permite a todos compreenderem aquela manifestação discursiva, que se fundou em um sistema partilhado e compreendido por todos.

Podemos a essa altura ver aclarar a idéia de que há uma parcela social no discurso, compreendida por todos os indivíduos e que, portanto, é passível de ser sistematizada e que deixa aberta a possibilidade de ser apropriada pelo sujeito da fala e se transformar em processo de acordo com uma série de posturas ideológicas, tornandose as mais variadas manifestações discursivas.

No presente trabalho o que se busca é a depreensão do sentido por meio da análise de textos valendo-se de recursos de base lingüística, em especial a semântica lexical, a semiótica e análise do discurso de linha francesa, todas teorias sólidas que oferecem modelos econômicos e eficientes para que se atinja o resultado que se pretende.

Considerando que o sentido está em todo tipo de formação textual, em que pese a maior beleza e, talvez, maior produtividade de citados modelos quando aplicados a textos poéticos, toma-se nesse trabalho como corpus as codificações civis brasileiras, responsáveis por regulamentar as relações entre indivíduos em sociedade em suas atividades cotidianas das mais variadas espécies, tais como celebração de contratos, criação de empresas, aquisição de imóveis e uniões de vínculo afetivo, como é o caso do casamento e da união estável, institutos aos quais é dado maior destaque nesse trabalho.

Uma vez estabelecidos os métodos de análise e o corpus a ser estudado, cabe informar que, em um primeiro momento, com vistas a inserir devidamente as codificações civis e as matérias que abrange dentro do léxico jurídico, o ponto de partida é a delimitação do que se entende por norma jurídica, em oposição a normas morais e religiosas para, a seguir, determinar-se em que domínio do ramo do Direito insere-se o Direito Civil. 
Ainda nessa análise preliminar, escorada na semântica lexical busca-se determinar o lugar ocupado pelas codificações civis no ordenamento jurídico e quais relações estabelecem com as demais leis do sistema jurídico positivo, tudo com a intenção de bem delimitar o objeto de estudo a ser abordado.

Encerrando a primeira fase da análise, a pesquisa volta-se para a consulta em dicionários da definição dos signos 'casamento', 'união estável' e 'concubinato', com o fito de servir de apoio para as pesquisas que se sucedem nos capítulos posteriores.

Assim, uma vez bem delimitado o objeto de análise, ou seja, as codificações civis e os signos que se referem a relações amorosas entre os indivíduos, para analisar como o sistema de signos torna-se processo de formação discursiva, a abordagem semiótica é apresentada, primeiro em suas linhas gerais e, após, em sua compleição jurídica, escorado nos estudos dos renomados mestres sobre o assunto.

Por fim, no último capítulo, por meio dos recursos emprestados da análise do discurso de linha francesa, as codificações civis são analisadas em busca da semântica global dos textos, operando-se o confronto entre os textos para se depreender as efetivas transformações operadas entre o Código Civil de 1916 e de 2002 e como ressoam no léxico, retomando as distinções semânticas dos signos abordadas ao longo da dissertação. 


\section{CAPÍTULO 1- ESTRUTURA SEMÂNTICA DAS CODIFICAÇÕES CIVIS}

Antes de adentrar nos pressupostos teóricos da semiótica jurídica, tratando-se de um estudo que engloba áreas do conhecimento diversas e complexas, como são o direito e a semiótica, faz-se necessário delimitar de que maneira a faceta jurídica é tratada sob essa concepção.

Em primeiro lugar, é importante esclarecer que, embora seja o direito positivo que será aqui analisado, não é pretensão recriar a teoria pura do direito ou qualquer outra concepção positivista do universo jurídico o que, certamente, levaria nossa empresa a resultados tautológicos.

O estudo se justifica por explorar um campo pouco percorrido nos estudos jurídicos, conferindo-lhe estatuto de formação discursiva, visando à sua compreensão enquanto formação textual produtora de sentido.

A pretensão é justamente conferir cientificidade ao estudo do Direito, compreendido como formação discursiva, afastando-se das diversas concepções do Direito de acordo com cada escola que procura estudar os institutos aqui tratados, conforme uma determinada linha de pensamento.

A exaustiva análise dessas teorias leva praticamente à conclusão de que o direito não possui bases teóricas sustentáveis e que, portanto, não pode ser considerado passível de compreensão pelas ciências, senão por uma abordagem retórica de construção de sentido.

Assim, em busca do sentido e, em consonância com o texto verbal a ser analisado, no presente capítulo trataremos de defini-lo sob a perspectiva da semântica lexical, para a melhor compreensão da inserção dos signos no dicionário jurídico, enfocando a rede de relações em que se funda para, no próximo capítulo colocar em prática a semiótica jurídica aplicada às codificações civis as quais, em um terceiro 
momento, serão também analisadas sob prisma de sentido por meio da análise do discurso de linha francesa.

Iniciando-se com a análise semântica dos signos que compõem o dicionário jurídico, há a possibilidade de estabelecer questões essenciais para os estudos semióticos, tais como a própria teoria do signo de Saussure e seus desdobramentos, além de bem delimitar o objeto de estudos da presente dissertação.

Com esse objetivo estabelecido, em um primeiro momento, o foco de análise será o próprio conceito de norma jurídica. Como já ressaltado no preâmbulo desse capítulo, a intenção não é oferecer estudo aprofundado e exaustivo das teorias que buscam, no âmbito jurídico, a explicação da teoria geral da norma.

A abordagem do tema aqui é menos jurídica e mais lingüística e, se dados da esfera jurídica abundarem na explanação, tal só ocorrerá na medida do necessário para a compreensão lingüística do tema o que, em última análise, não difere muito da maneira como os lingüistas preocupados com literatura abordam a questão.

Uma vez compreendido, sob o enfoque semântico-lexical, o sentido de norma jurídica, passaremos a tratar da rede de relações que conferem sentido às normas jurídicas enquanto engrenagens lingüísticas para o funcionamento do aparato jurídico.

Isso com vistas a bem delimitar o lugar discursivo ocupado pelas codificações nesse emaranhado de normas e, em especial, as codificações civis, objeto de estudo dessa dissertação.

Em um segundo momento, a análise componencial se voltará para o instituto do casamento e da união estável, com o objetivo de compreender um signo pelas oposições semânticas que estabelece com o outro, sem perder de vista a base social de toda construção discursiva e como se caminha de um fato social (do mundo "natural") para um fato com relevância e conseqüências jurídicas, concluindo-se se é possível uma distinção meramente conceitual entre normas jurídicas, morais e religiosas, bem como o estudo fracionado dos diversos ramos do Direito, ou se o que há são relações de 
imbricação e implicações mútuas que vão formando o vocabulário jurídico que delimita o campo de análise do Direito.

\section{Normas religiosas, morais e jurídicas}

No mais das vezes não é o direito que cria as situações de vida em sociedade, mas, pelo contrário, por outras condicionantes os indivíduos passam a agir desta ou daquela maneira e o direito, por meio de seu conjunto de regras, para não ficar distante da sociedade, normatiza as condutas para torná-las de acordo com o ordenamento jurídico.

Varia a maneira como o sistema jurídico normatiza as mais variadas condutas sociais, que podem ser recepcionadas de maneira positiva, atribuindo-lhe a norma jurídica um valor /conforme o direito/, de maneira negativa, atribuindo-lhe um valor /em desacordo com o direito/, ou tomando uma postura neutra em relação ao tema /juridicamente inexistente/. Explica-se.

O Código Civil de 2002, ao lado do casamento, conforme se estudará mais adiante, recepciona a união estável, que define, em seu artigo 1.723 da seguinte maneira:

"É reconhecida como entidade familiar a união estável entre o homem e a mulher, configurada na convivência pública e duradoura e estabelecida com o objetivo de constituição de família."

Temos, portanto, que ainda que não estejam casados de direito, homem e mulher que convivem como se casados fossem, estabelecem uma entidade familiar à qual o direito confere direitos e deveres recíprocos.

Daí podemos concluir que a recepção pelo ordenamento jurídico de um signo (união estável) implica a inclusão no léxico jurídico de um termo com novo significante e significado, que se opõe ao casamento e às formas de união entre indivíduos não recepcionadas ou repelidas pelo ordenamento. Eis uma normatização positiva de determina instituto, nesse caso, a união estável. 
É também pelo léxico que podemos notar a anulação que opera, ao reconhecer a união estável apenas na relação afetiva entre "homem" e "mulher", no que se refere a relações entre pessoas do mesmo sexo.

A dicção legal é bem clara e, certamente ao operá-la condicionando o reconhecimento legal da relação, dentre outros, pela união entre pessoas de sexo oposto, quis deixar à margem do direito as relações homossexuais.

Certamente esse caso não pode ser considerado uma normatização negativa de determinada conduta social, eis que essa última é bem mais explícita nos seus mecanismos lingüísticos.

Veja o que dispõe o artigo 1.521, I do Código Civil de 2002:

"Não podem casar: I - os ascendentes com os descendentes, seja o parentesco natural ou civil.”.

Não há mera desconsideração pelo ordenamento jurídico da relação entre pais e filhos, ainda que adotivos, mas recepção negativa pelo ordenamento jurídico, conferindo-lhe o traço /em desacordo com o ordenamento/.

Para esse caso, da mesma forma, não é possível reconhecer essa relação como união estável, eis que o parágrafo primeiro do já citado artigo 1.723 estipula que não se constitui união estável em virtude dos impedimentos para celebração do casamento previstos no art. 1.521 do Código Civil de 2002.

Eis aí um bom enfeixamento de signos jurídicos que pretendem "fechar as portas" para o reconhecimento jurídico de algo que é previsto como em desacordo com o direito. Voltaremos a essa questão mais a frente. ${ }^{1}$

\footnotetext{
${ }^{1}$ E, o art. 1.727 do Código Civil define essas relações como concubinato: "As relações não eventuais entre o homem e a mulher, impedidos de casar, constituem concubinato".
} 
Por hora, cabe aproveitar algo que salta aos olhos do que foi dito acima: a estreita relação entre normas religiosas, morais e jurídicas. Pensemos nos signos tratados: casamento, união estável, relações concubinárias e homossexuais. A cada uma delas o direito dá um tratamento diverso, muito provavelmente influenciado pelas referidas normas de outra natureza.

Ora, o casamento, desde suas notícias mais remotas, sempre teve relação com rituais litúrgicos, notadamente nos tempos em que Igreja e Estado eram compreendidos como Instituições indissociáveis, quer seja na Grécia Antiga, em Roma ou nas trevas da Idade Média, ou até mesmo nos Estados Modernos, que acabaram por conferir estatuto de "direito natural" à união entre homens e mulheres para constituir família, a "célula" da sociedade.

Com tendências homossexuais a sociedade sempre conviveu e fechou os olhos a elas, desde as festas gregas às orgias secretas nos castelos medievais, passando por Roma e operando até os dias de hoje.

Já as relações incestuosas, incentivadas e proliferadas nos povos do Egito, repudiadas e sancionadas negativamente na Grécia Antiga, notadamente com o advento da Igreja Católica passam a ter conotação negativa, afastando-a do que se considera normal em vida em sociedade.

Cabe, portanto, estabelecer os traços semânticos distintivos entre normas religiosas, morais e jurídicas. Frise-se: o que se pretende aqui não é esgotar todo o debate filosófico a cerca do tema, mas apenas conferir estatuto lingüístico às oposições que se estabelecem entre referidos signos, adotando-se, sem maiores delongas, determinadas posturas filosóficas para não perder o foco pretendido. 
Como o foco da dissertação é a norma jurídica, as concepções positivistas do Direito ganham relevo, uma vez que é por meio de tal doutrina que fica mais evidente a possibilidade de efetiva aproximação entre o sistema de normas jurídicas e os pressupostos teóricos da lingüística, como bem observa Comparato ${ }^{2}$.

O que se propõe a seguir, portanto, é estabelecer os campos semânticos que compreendem as normas morais, religiosas e legais, tratando de diferenciá-los por meio da relação entre os seus respectivos significantes e significados, sob uma concepção saussuriana.

Sob a concepção saussuriana de linguagem temos que o sistema lingüístico é composto por signos, que encerram uma relação entre um significante e um significado afastado, portanto, da concepção de linguagem como relação entre palavras e coisas, conforme a tradição clássica ${ }^{3}$.

Mais do que isso, adotando-se a concepção de Saussure, compreende-se que a linguagem é formação social e o significado dos termos é compreendido nas relações estabelecidas entre os signos. Significante e significado são duas faces da mesma moeda, que criam um todo de sentido.

Para a melhor compreensão dessa abordagem lingüística, cabe salientar a maneira como as diversas línguas naturais compõem seu sistema de relações entre os signos.

${ }^{2}$ COMPARATO, Fábio Konder. Ética - direito, moral e religião no mundo moderno. São Paulo. Companhia das Letras, p. 351: “A partir de Augusto Comte, o pensamento positivista desenvolveu-se sucessivamente no campo filosófico em empriocriticismo, positivismo lógico, empirismo lógico e, finalmente, no século XX, em filosofia analítica e lingüística”.

${ }^{3}$ Pietroforte/Lopes in "Introdução à Lingüística - II. Princípios de análise.” Organizador: José Luiz Fiorin, 01 ${ }^{\mathrm{a}}$ Edição. Contexto. P. 111-136. 
Exemplo clássico disso poderia ser a distinção que a língua inglesa estabelece entre fingers (dedos das mãos) e toes (dedos dos pés) o que, na língua portuguesa, não se estabelece como distinção relevante, uma vez que dedos podem se referir tanto a dedos dos pés como das mãos.

Isso significa que a língua inglesa é mais rica na distinção entre termos do que a língua portuguesa? Por certo que não, apenas demonstra as possíveis divergências de visão de mundo em cada língua natural, ao estabelecer as relações entre os signos que a compõem. Donde concluímos que a linguagem é, fundamentalmente, construção social.

Voltando o foco para as normas temos que todas elas, tanto normas religiosas como normas morais e jurídicas convivem harmonicamente no universo cultural das mais diversas nações.

Se é certo que em muitos casos assemelham-se sobremaneira, também não se pode deixar de notar que cada qual tem campo de atuação distinto, em razão de traços semânticos que determinam as distinções.

E, é justamente por podermos observar traços semânticos que os aproximam, bem como que os distinguem que se torna possível a análise de tais normas por meio da perspectiva teórica aqui determinada.

Conforme observações anteriores, temos que o conceito de norma, em sentido amplo, engloba todos os preceitos de previsões que vinculam o modo de agir do indivíduo em sociedade.

Já se esclareceu que as normas prevêem condutas de acordo com certa normalidade nas questões sociais. Cabe agora definir os traços semânticos que distinguem umas normas das outras.

Todas as normas guardam em si o fato de serem previsões de condutas humanas que vinculam a postura dos homens em sociedade. Todas elas, portanto, são da ordem do dever-ser. O que as diferencia, então? 
Ilustrando: determinada religião pode prever como em desacordo com seus ditames a união entre pessoas sem o cumprimento dos respectivos rituais litúrgicos. Sob tal perspectiva religiosa esses indivíduos são sancionados negativamente por desobedecerem a um preceito que vincula os adeptos de determinada religião.

Mas, basta que esses indivíduos não se postem como fiéis a tal religião para que a reprovação ali prevista não os atinja de qualquer forma. Isso porque não se obrigam a cumprir aquilo que não têm como preceito religioso para validação de seus atos.

Assim, a união de pessoas não recoberta pelo manto normativo de determinada religião apenas torna tal união em desacordo com parâmetros aos quais não estão obrigados a se submeter, a não ser por manifestação volitiva de atrelar-se a tais rituais.

Em sede de semiótica, poderíamos dizer que não há uma relação fiduciária entre os indivíduos e determinada concepção religiosa de dever-ser, que torna uma possível manipulação por parte da igreja inócua, eis que não compartilhada por aqueles que praticam o ato em desacordo e que, por isso, não se sentem sancionadas negativamente pela reprovação de determinada religião.

Da mesma forma, ainda que moralmente não se admita como digna a união entre pessoas do mesmo sexo, porque em desacordo com a moralidade média de determinado grupo social, esses indivíduos podem passar a conviver como se marido e mulher fossem e, ao arrepio da reprovação social, podem estabelecer esse tipo de relacionamento, ainda que arcando com evidente marginalização por parte do grupo social ao qual pertencem.

Nos casos das normas religiosas e morais, portanto, podemos dizer que a sanção pelo descumprimento do dever-ser é "internalizada", ou seja, caso o indivíduo não se sinta coagido a agir desta ou daquela maneira, não se sentirá sancionado negativamente, porque não conflitante com sua moralidade interna.

Por outro turno, àqueles que se sentem afrontados por tais condutas, resta apenas e tão somente segregar o indivíduo infrator do convívio social, não podendo obrigá-lo coercitivamente a praticar ou deixar de praticar determinado ato. 
É assim que o Padre da Igreja Católica, que administra determinada paróquia pode recusar-se a batizar o filho do casal que não se casou na Igreja, da mesma forma que o casal homossexual pode não ser convidado para as festas dos moradores do condomínio, nada mais.

Diferente é o resultado dos atos dos indivíduos quando confrontados com o ordenamento jurídico propriamente dito. Nessa esfera, o comportar-se em desacordo com as normas jurídicas corresponde, ainda que indiretamente, a um determinado tipo de sanção aos quais estão sujeitos, muito embora não queiram a ela se submeter.

Isso porque, na qualidade de jurisdicionados, devem obediência ao dever-ser estabelecido nas normas jurídicas, que independem da vontade dos indivíduos. Pelo contrário, a ele os indivíduos devem se submeter, sob pena de sofrerem as conseqüências legalmente previstas pela desobediência do previsto em lei.

Portanto, a ordem jurídica prevê uma obediência compulsória, sem a qual os atos realizados pelos indivíduos são considerados em desacordo com o ordenamento jurídico, aos quais forçosamente aderem por estarem sob a égide das previsões legais de determinado Estado de Direito ${ }^{4}$.

Equivale a dizer que as normas jurídicas independem da internalização de seus preceitos pelo indivíduo, sendo o mesmo sancionado pelo que externaliza como conduta

${ }^{4}$ De acordo com Hans Kelsen (“Teoria Pura do Direito". 6 6 Edição. Trad. João Baptista Machado. Ed. Martins Fontes. 2005. pág. 39) "Enquanto diferentes ordens jurídicas coincidem globalmente quanto aos atos de coação por elas estatuídos e atribuíveis à comunidade jurídica este consistem sempre, com efeito, na privação forçada dos bens mencionados -, divergem consideravelmente pelo que respeita aos pressupostos a que esses atos de coação estão ligados, particularmente quanto à conduta humana cuja contrária deve ser obtida através da estatuição de sanções, isto é, quanto à situação garantida pela ordem jurídica e socialmente desejada, consistente na conduta conforme ao Direito, ou seja ainda, quanto ao valor jurídico que é constituído através das normas." Deste trecho da obra do mestre genibrino, fica clara a concepção da ordem jurídica em razão da sua coercitibilidade, relacionada à conduta humana externalizada." 
conforme ou não ao ordenamento jurídico. Não é que a intenção do indivíduo não importe, mas a mera intenção não merece regramento autônomo por parte do sistema jurídico.

O autor de um homicídio pode não ter tido a intenção de cometer tal ato, o que se operou por imperícia no manejo de arma de fogo, no entanto será sancionado negativamente pelo ordenamento jurídico, por meio de imposição de pena restritiva de liberdade. Nesse caso, a intenção do agente será considerada meramente para o dosimetria da pena ${ }^{5}$.

De outra banda, pode não ser a intenção do agente arcar com pensão alimentícia para seu filho, no entanto, por obediência à lei, pelo temor à sanção ele o faz, e assim sendo afastando sua conduta de sua intenção, age conforme o ordenamento jurídico.

Temos aí, finalmente, distinções semânticas pertinentes entre normas religiosas, morais e jurídicas, que é o elemento de coercitividade e externalidade desta última, independente da vontade de a eles se vincular por parte do jurisdicionado.

Uma vez atrelado a determinado ordenamento jurídico, o sujeito deve a ele obediência irrestrita e será sancionado positiva ou negativamente de acordo com a postura que tomar diante de determinada previsão legal.

\footnotetext{
${ }^{5}$ De acordo com art. 59 do Código Penal: "O juiz, atendendo à culpabilidade, aos antecedentes, à conduta social, à personalidade do agente, aos motivos, às circunstâncias e conseqüências do crime, bem como ao comportamento da vítima, estabelecerá, conforme seja necessário e suficiente para reprovação e prevenção do crime: I - as penas aplicáveis dentre as cominadas; II - a quantidade de pena aplicável, dentro dos limites previstos; III - o regime inicial de cumprimento da pena privativa de liberdade; IV - a substituição da pena privativa de liberdade aplicada, por outra espécie de pena." Note que referido artigo de lei trata do momento da aplicação da sanção penal, após a análise judicial do caso, portanto. Só é possível determinar-se todas as circunstâncias do crime acima referidas no seu confronto com o caso concreto, o que se faz por meio do devido processo legal, momento de se perquirir sobre as motivações para o cometimento do delito.
} 
Filosoficamente, para não nos perdermos em um sem-fim de conceitos, podemos dizer que essa obrigação advém do contrato social, ao qual todos aderem para a formação do Estado e garantia da paz social. Contrato social que é abstração teórica para a explicação lógica do manto estatal que recobre todos aqueles que daquele Estado participam.

Cumpre esclarecer que a norma jurídica, como aparato estatal de manutenção de certa ordem e paz social, nem sempre está de acordo com certos anseios morais da sociedade (e que podem ser expressos por normas sociais),

No entanto, não é o juízo de valor moral que se faz da norma capaz de retirar da norma jurídica seu caráter de imposição de conduta em sociedade.

Com efeito, conforme a ordem estatal e eclesiástica vão se distanciando no curso da História da humanidade, enquanto a sociedade civil vai delineando seu modo de existência por meio da evolução dos meios de produção, afastando-a também do arcabouço dos imperativos religiosos ${ }^{6}$, o que parece é que cada uma dessas entidades passa a construir o seu universo de valores, determinando sua abrangência.

Não sendo possível capturar todas e quais efetivamente são as normas sociais vigentes, uma vez que não estão escritas e elencadas em um possível "Código Moral de Vida em Sociedade", só podem ser depreendidas do ideário, do universo axiológico de determinada sociedade.

Temos, portanto, que esse universo de valores que pode permear determinado grupo social não se comunga com o conjunto de valores de outros grupos, o que obriga o homem, para conviver nos mais diversos estratos sociais, a compreender, por experiência, o enquadramento axiológico daquele grupo social e passar a se comportar, naquelas ocasiões (pelo menos) de acordo com o universo de valores daquele grupo.

\footnotetext{
${ }^{6}$ COMPARATO, Fábio Konder. "Ética - Direito, Moral e Religião no Mundo Moderno.” 01 ${ }^{\mathrm{a}}$ Edição. Companhia das Letras. 2006.
} 
É aqui que se explicam as dificuldades de adaptação de estrangeiros aos valores sociais de uma cultura que desconhecem. Só para ficar no trivial, um coreano que passa a residir no Brasil e que em seu país de origem se alimentava com carne canina, ao chegar ao Brasil surpreende-se com o valor afetivo que é atribuído pelo brasileiro aos cães, incorpora que não deve concebê-los como alimento, mas como animal de estimação.

Em uma outra cultura, poder-se-ia sacralizar os gados e, um brasileiro que se alimenta com carne de vaca, incorporando referida tradição, deveria deixar de se alimentar com a carne daquele animal e passar a cultuá-la.

É uma tarefa árdua essa de incorporar conceitos sociais, ainda mais quando se adentra nas micro-sociedades que compõem determinado corpo social, notadamente porque não as encontramos em algum lugar, mas no interior da cultura de determinada nação.

Já quando o assunto é norma jurídica, o mesmo problema não é enfrentado, uma vez que o estrangeiro pode valer-se do conjunto de norma vigentes em determinada nação e compreender quais condutas humanas são reconhecidas como crimes em determinado ordenamento; quais os princípios constitucionais que regem aquela nação; como deve agir para ser estrangeiro regular; como deve agir para constituir uma empresa; para celebrar casamento civil, etc.

Quando a questão é de fundo religioso, a internalização das normas também é traço semântico característico, diferenciado-se das normas morais, no entanto, primeiro porque é possível depreender por um sistema escrito quais os valores (normas) caros a determinada religião (Os "Livros Sagrados") e segundo porque a imposição da sanção não se dá pelos próprios membros de determinada sociedade, mas por meio da manifestação da vontade divina.

Provavelmente por essa razão que a concepção positivista do Direito acaba por esvaziar o sistema jurídico de questões axiológicas, bastando para o sistema a concepção de validade, vigência e eficácia da norma jurídica como controlador da conduta humana em sociedade. 
Assim, excluindo do ordenamento jurídico a questão da moralidade, ainda que se prefira as norma morais às imorais, tais assertivas deixam de ter relevância, operando o direito como um sistema de normas em que uma ganha significado nas relações de hierarquia e subordinação que mantêm com as demais normas que compõem determinado ordenamento jurídico. Nesse caso, o "bom" é o que "deve ser", que corresponde a uma norma ${ }^{7}$.

Assim, com base nas reflexões acima, podemos apresentar o seguinte quadro de cotejos de traços semânticos entre normas morais, religiosas e jurídicas:

\begin{tabular}{|l|l|l|l|l|}
\hline & DEVER- SER & HETERÔNIMA & $\begin{array}{l}\text { INTERSUBJET } \\
\text { IVA }\end{array}$ & COGENTE \\
\hline $\begin{array}{l}\text { NORMAS } \\
\text { MORAIS/RELIG } \\
\text { IOSAS }\end{array}$ & + & - & + & - \\
\hline $\begin{array}{l}\text { NORMAS } \\
\text { JURÍDICAS }\end{array}$ & + & + & + & + \\
\hline
\end{tabular}

${ }^{7}$ KELSEN, Hans. Teoria Pura do Direito. São Paulo. Martins Fontes. 2003. p. 75 "Se supusermos que o Direito é, por sua essência, moral (tem caráter moral), então não faz sentido a exigência - feita sob o pressuposto de existência de um valor moral absoluto - feita sob o pressuposto da existência de um valor moral absoluto - de que o Direito deve ser moral. Uma tal exigência apenas tem sentido, e a Moral para o efeito pressuposta somente representa um critério de valoração relativamente ao Direito, quando se admite a possibilidade de um Direito imoral, de um Direito moralmente mau, e, por conseqüência, quando na definição de Direito não entre o elemento que representa um conteúdo moral. (...) Mas com isto não fica excluída a possibilidade da pretensão que exija que o Direito Positivo deve harmonizar-se com um outro sistema moral e com ele venha eventualmente a concordar de fato, contradizendo um sistema moral diferente deste. Se, pressupondo a existência de valores meramente relativos, se pretende distinguir o Direito da Moral em geral e, em particular, distinguir o Direito da Justiça, tal pretensão não significa que o Direito nada tenha a ver com a Moral e com a Justiça, que o conceito de Direito não caiba no conceito de 'bom'. Na verdade, o conceito de 'bom' não pode ser determinado senão como "o que deve ser", o que corresponde a uma norma. Ora, se definimos Direito como norma, isto implica que o que é conforme-ao-Direito (das Rechtmässige) é um bem." 
Por meio da análise do quadro acima, resta claro que o traço semântico que aproxima normas morais, normas religiosas e normas jurídicas é o fato de todas serem esquemas de previsões de normalidade de conduta em sociedade, ou seja, são todas da ordem do dever-ser e intersubjetivas.

A heteronímia e a coercitividade são os elementos que diferenciam as normas jurídicas das demais. Cumpre também esclarecer que a grande diferença das normas morais e religiosas é o agente sancionador: no caso das normas morais a sociedade civil é quem opera a sanção da conduta, por meio de mecanismo de reprovação e de exclusão social; no caso da norma religiosa, a sua desobediência leva à sanção pela divindade, que escolherá a sorte do indivíduo em vida e no porvir ${ }^{8}$.

Só a norma jurídica incorpora efetivamente a qualidade da heteronomia, uma vez que são normas atributivas de conduta que partem do Estado para a esfera individual. Além disso, são normas cogentes, uma vez que o Estado tem o poder de lançar mão dos meios coercitivos para obrigar os indivíduos a determinada conduta prevista em lei.

Por isso dizemos que a norma jurídica é cogente. As normas morais e religiosas só se revestem do traço de coercetibilidade no caso de serem amparadas, indiretamente pelo ordenamento jurídico 9 .

\footnotetext{
${ }^{8}$ Vale alertar que sob essa concepção tomamos os normas morais e religiosas que não são escritas e firmadas entre as partes, isso porque no caso de uma convenção escrita de um clube, por exemplo, podem haver determinações de conduta nas suas dependências, que se inserem no conjunto de regras do ordenamento jurídico; como é o caso também do Direito Canônico, que impõe conduta aos seus membros e fiéis, mas aí já de acordo com a norma jurídica. Portanto, as normas morais a que nos referimos são aquelas que não são passíveis de manifestação judicial a seu respeito, impondo aquela conduta. Ou seja, o Padre, responsável por determinada paróquia não pode ingressar com ação judicial de obrigação de fazer para compelir aqueles que não casaram na Igreja, que sejam obrigados a fazê-lo; ao mesmo tempo em que um vizinho não pode requerer um juízo que se impeça um casal homossexual a viverem sob o mesmo teto e de manterem relações sexuais.

${ }^{9}$ Pegue-se, por exemplo, o crime de ato ultraje público ao pudor, previsto no art. 233 do Código Penal: "Praticar ato obsceno em local público, ou aberto ou exposto ao público. Pena -
} 
Por meio dessa análise preliminar, embora não tenha se esgotado o debate sobre o campo de atuação das normas abordadas (o que não era nossa intenção), a análise sêmica implementada possibilitou a determinação daquelas normas das quais nos ocuparemos no decorrer desse trabalho, sem prejuízo de notar, sempre que possível, a evidente imbricação entre os anseios morais, religiosos e a norma jurídica, notadamente no estudo do tema central em debate: as relações afetivas entre as pessoas, por meio da análise dos institutos do casamento e união estável.

\section{O sistema normativo jurídico}

\section{1 direito público e direito privado}

O direito, ao pretender-se como discurso autônomo, destacado dos discursos produzidos em língua natural em geral, confere a cada termo que compõe o seu dicionário (léxico) carga semântica específica, determinando o sentido de cada termo que propõe na relação que estabelece com os demais termos da rede de relações que conferem sentido ao discurso jurídico.

Sob uma percepção lingüística de linha saussuriana, é possível afirmar que o discurso jurídico pretende tornar monossêmicos termos que, em sentido amplo, são manifestamente polissêmicos.

detenção, de 3 (três) meses a 1 (um) ano, ou multa." Nesse caso, a vizinha preocupada com a moralidade do condomínio pode exigir do Estado pela conduta imoral de jovens que namoram ostensivamente na área comum do prédio. Mas não pela questão moral em si, mas porque está prevista no ordenamento jurídico.

Outro bom exemplo é o art. 208 do mesmo diploma legal, tipificado como "Dos Crimes Contra o Sentimento Religioso": "Escarnecer de alguém publicamente, por motivo de crença ou função religiosa; impedir ou pertubar cerimônia ou prática de culto religiosos; vilipendiar publicamente ato ou objeto de culto religioso: Pena - detenção, de 1 (um) mês a 1 (um) ano, ou multa." Assim, no caso que ficou famoso em meados dos anos 90 do século passado, o bispo que desferiu golpes contra uma imagem de Santo cultuado pela Igreja Católica, merece punição estatal em razão de referida previsão legal e não de uma possível norma religiosa. 
Como advertem Pietroforte e Lopes $(131: 2003)^{10}$ :

"A polissemia e a monossemia estão relacionadas ao uso discursivo que se faz de uma mesma palavra. Em geral, são os vocabulários técnicos que, por meio de definições construídas em seus discursos, operam modificações sêmicas que transformam palavras polissêmicas em monossêmicas."

O exemplo clássico que utilizam para explicar esse fenômeno é a distinção que o discurso jurídico faz do tipo penal que define "furto" do tipo penal que define "roubo", demarcando uma distinção de sememas entre ambos, eis que o primeiro é definido, no ordenamento pátrio, como a subtração de coisa alheia móvel, ao passo que o segundo é a subtração de coisa alheia móvel mediante violência ou grave ameaça.

A princípio, no vocabulário coloquial, não há grave equívoco ao se utilizar o signo furto como sinônimo de roubo, o que se faz usualmente. Agora, tendo o discurso jurídico conferido carga semântica distinta a cada um deles, para os que comungam de tal vocabulário, tornar-se equívoca a relação de sinonímia entre ambos.

Poderia haver legislação que não traçasse distinções semânticas entre ambos? Por certo que sim (embora não seja essa a tendência geral das legislações em geral), eis que o sentido é dado na relação que se estabelece entre os signos, ganhando cada um seu significado na oposição observada.

Daí também é possível se concluir que, para dois signos serem considerados opostos e passíveis de conferir sentido na relação que estabelecem devem guardar, ao menos, um traço comum de significação.

Aqui também ganha relevo o conceito de semântica lexical de hiperonímia e hiponímia, definindo-se o signo hiperonímico como aquele cujo domínio semântico mais abrangente e os signos hiponômios, que são englobados por aqueles ${ }^{11}$.

${ }^{10}$ Ob. Cit. p. 131 
É notável a direta relação entre a noção de sistema de linha saussurreana e a taxionomia do sistema jurídico, que distribui suas categorias justamente por ramos do direito, uns que abrangem outros e outros ainda que se distinguem em razão de sua matéria.

Tome-se de início, a análise que vimos fazendo da distinção entre furto e roubo, temos que esses lexemas (compreendidos como entradas em um dicionário jurídico) tratam de conferir sentido mutuamente por traços característicos que os aproximam (crimes contra o patrimônio) e por sememas que os distinguem (subtração sorrateira no caso de furto e subtração mediante violência no caso de roubo) ${ }^{12}$.

Retroagindo, temos que ambos os termos estão englobados dentro de um mesmo campo semântico, que são "crimes contra o patrimônio"13 que se opõem, por sua vez, por exemplo, ao campo semântico que compõem os "crimes contra a vida"14.

No primeiro caso, a conceituação do crime está ligada à relação que os indivíduos estabelecem com as coisas passíveis de apreensão pelos homens, é a propriedade privada que visa a proteger. No segundo caso é a incolumidade física dos indivíduos que é protegida, nas relações que se estabelecem exclusivamente entre indivíduos.

${ }^{11}$ PIETROFORTE/LOPES. Ob. Cit. 128. Os autores, na pág. 128, com muita propriedade esclarecem que "A hiperonímia e a hiponímia são fenômenos derivados das disposições hierárquicas de classificação próprias do sistema lexical. Há significados que, pelo seu domínio semântico, englobam outros significados menos abrangentes. Na taxionomia animal, por exemplo, mamífero engloba felino, canídeo, roedor, primata, etc.

$12 \mathrm{O}$ art. 155 define furto da seguinte forma: "Subtrair, para si ou para outrem, coisa alheia móvel". E, no art. 157, define roubo: "Subtrair coisa móvel alheia, para si ou para outrem, mediante grave ameaça ou violência a pessoa, ou depois de havê-la, por qualquer meio, reduzido à impossibilidade de resistência".

${ }^{13}$ previstos na Parte Especial, Título II do Código Penal.

${ }^{14}$ Previstos no Título I da Parte Especial do Código Penal. 
É por isso que o latrocínio é previsto como conseqüência mais grave de crime contra o patrimônio (roubo “qualificado", conforme artigo 157, $\S 3^{\circ}$ do Código Penal ${ }^{15}$ ), uma vez que o evento morte só ocorre em razão da relação patrimonial. Não era a vida da vítima o que visava o agente, mas seu patrimônio. Se o evento morte ocorre é por mero desdobramento da violência operada para a apropriação da res.

Situação diversa seria a da filha que mata os pais para receber herança e, assim, viver tranquilamente com seu namorado. Ainda que seja simulado um latrocínio, a morte dos pais é o foco da agente que, cometendo um crime contra a vida, tem como resultado prático a obtenção de patrimônio.

Não há aqui consideração a cerca da gravidade da conduta, mas apenas o enquadramento da conduta em determinado tipo penal e, mais ainda, em determinado grupo de crimes que guardam uns, maior relação com o patrimônio, outros maior relação com a incolumidade física.

Retroagindo ainda mais, temos a distinção clássica entre os ramos do direito público e privado, que remonta ao Direito Romano, quando tal dicotomia fora cunhada $^{16}$, distinguindo um do outro por meio do critério da utilidade, ou seja, se diziam respeito às coisas do Estado ou às coisas do particular.

Assim, o Direito Penal seria um ramo do direito público, uma vez que seu conjunto de normas visa a conferir segurança jurídica à sociedade, e o direito civil, por exemplo e por excelência, o ramo do Direito Privado comum, uma vez que regula a vida dos particulares (questão que será tratada de forma detalhada mais adiante).

\footnotetext{
${ }^{15}$ Art. 157, $\S 3^{\circ}$ do Código Penal: "Se da violência resulta lesão corporal grave, a pena é de reclusão, de 7 (sete) a 15 (quinze) anos, além da multa; se resulta morte, a reclusão é de 20 (vinte) a 30 (trinta) anos, sem prejuízo da multa.

${ }^{16}$ Ulpiano, Digesto. "Hujus studii duae sunt positiones, publicum et privatum. Publicum jus est, quod ad statum rei Romanae spectat, privatum quod ad singolorum utilitatem; sunt enin quaedam publice utilia, quaedam privatim".
} 
Tal distinção, por meio desse único critério há tempos é refutada como suficiente para bem fundamentar pretendida divisão que, se existe, necessita de uma aprofundada pesquisa sobre seus efetivos traços de antonímia ${ }^{17}$.

Tradicionalmente, os ramos de direito apontados pela doutrina jurídica, com poucas distinções, subdivide o direito da seguinte forma ${ }^{18}$ :

\section{I - Direito Público:}

1) Interno:

- Direito Constitucional

- Direito Administrativo

- Direito Financeiro

- Direito Tributário

- Direito Judiciário

- Direito Penal

2) Externo:

- Direito Internacional Público

\section{II - Direito Privado:}

1) comum:

- Direito Civil

2) especial

- Direito Comercial

- Direito do Trabalho

- Direito Internacional Privado

\footnotetext{
17 Antônimos são signos que possuem significados opostos, como bonito/feio, claro/escuro, alto/baixo e, também público/privado.

${ }^{18}$ MONTORO, André Franco. "Introdução à Ciência do Direito”. $21^{a}$ Edição. Editora RT. 1993. (p 112).
} 
No entanto, da análise de normas jurídicas, sejam elas de direito penal, civil, direito do trabalho, comercial, processual ou constitucional não se depreende esta efetiva distinção público/privado.

Ora, se o Direito Penal é ramo do Direito Público, porque vai se preocupar em tratar de crimes contra a entidade familiar, formada por particulares em relação? E é isso que faz o legislador no Título VII, Capítulo I da Parte Especial do Código Penal, ao tipificar a bigamia ${ }^{19}$, o induzimento a erro essencial e ocultação de impedimento ${ }^{20}$, bem como nos capítulos II (crimes contra o estado de filiação), III (crimes contra a assistência familiar) e IV (crimes contra o pátrio poder, tutela ou curatela).

De outro lado, se ao direito civil importa apenas a relação entre particulares, porque deveria incluir normas que tratam do bem comum e da função social da propriedade? Ora, no plano individual, o que importa são os bens sem suas relações /privadas/ e não considerações sobre o coletivo, o /público/.

Mais ainda, o instituto do casamento também está previsto na Constituição Federal, dentro do Título VIII, que dispõe sobre a ordem social, considerando a família a base da sociedade, com especial proteção do Estado (CF/88, art. 226) ${ }^{21}$. E o Direito Constitucional não é ramo do Direito Público?

Sendo assim, é preferível tratar da distinção específica entre o que se convencionou denominar em direito por Direito Penal e por Direito Civil, por exemplo, e delinear o que efetivamente são traços semânticos que opõem os signos.

\footnotetext{
${ }^{19}$ Código Penal, Art. 235. "Contrair alguém, sendo casado, novo casamento. Pena - reclusão de 2 (dois) a 6 (seis) anos.

${ }^{20}$ Código Penal, art. 234. "Contrair casamento, induzindo em erro essencial o outro contraente, ou ocultando-lhe impedimento que não seja casamento anterior. Pena - detenção, de 6 (seis) meses a 2 (dois) anos".

${ }^{21}$ Constituição Federal, art. 226: “A família, base da sociedade, tem especial proteção do Estado."
} 
Ao que tudo indica quando maior relevo é dado ao interesse público, cabe ao Estado operar a sanção. Quando maior relevo é dado ao interesse privado, cabe ao particular, por meio do aparelho judiciário, buscar a sanção do infrator da lei.

É por isso que o legislador, ao categorizar os tipos penais na Parte Especial do Código Penal prevê as sanções aplicáveis, que sempre são privativas de liberdade (detenção e reclusão).

Já ao longo do Código Civil em momento algum à determinada conduta é atrelada sanção corpórea, sancionando-as com base no patrimônio (como quando prevê o pagamento de multa ao condômino que deixa de arcar com as cotas condominiais na data aprazada).

Portanto, nas relações civis a punição do infrator é sempre pecuniária ou que pode ser convertida em pecúnia, até mesmo nos casos expressos e excepcionais de prisão civil do depositário infiel e do devedor de alimentos, eis que a privação de liberdade cessa no mesmo momento em que referidos devedores satisfazem sua obrigação pecuniária.

No campo do direito penal temos situação diversa, uma vez que o caráter pecuniário da sanção, a satisfação material da lesão, tem finalidade meramente acessória e não inibe o cumprimento da sanção privativa de liberdade.

Isso significa que, mesmo que aquele que causou lesões corporais dolosas e gravíssimas a outrem arque com todas as conseqüências materiais de seu ato, dando pleno amparo à vítima e à sua família, ainda assim não se furtará ao efetivo cumprimento da pena privativa de liberdade.

Portanto, o traço semântico distintivo entre as duas áreas do direito é justamente o modo pelo qual se opera a sanção e, a partir daí a determinação de quais condutas são consideradas pelo ordenamento jurídico como relevantes para fins de direito civil e para fins de direito penal, consideradas aquelas menos graves e essas mais graves. 
Vejamos se, em confronto, as definições de Montoro para direito penal e direito civil confirmam nossa hipótese:

“O direito penal pode ser definido como o ramo do Direito Público que regula a atividade repressiva do Estado, definindo os crimes $e$ determinando as penas e medidas de segurança aplicáveis. (...)Ele é, em primeiro lugar, um ramo do Direito Público, porque regula uma das atividades do Estado, que é a atividade repressiva. (...)Em segundo lugar, empregando a palavra crime em sentido amplo, dizem que o Direito Penal define os crimes, isto é, as infrações penais graves (crimes, em sentido estrito) e as infrações penais leves (ou contravenções).”22

“Direito Civil é o Direito Privado comum, que, na fórmula de Vicente Ráo, “Disciplina o estado e a capacidade das pessoas e suas relações de caráter privado, atinentes à família, às coisas, às obrigações e à transmissão hereditária dos patrimônios”. (...). ${ }^{23}$

Parece que no caso do Direito Penal, maior relevo é dado ao seu caráter punitivo, que a partir daí regula condutas e previne sanções. A relação é diretamente entre o sujeito-infrator e o Estado-sancionador.

Já no caso do Direito Civil maior relevo é dado às relações entre os indivíduos, de caráter privado, fruto da manifestação de vontade desses, na maior parte dos casos. Aqui o sinalagma ${ }^{24}$ faz-se imperioso.

Se é bem verdade que, em ambos os casos, opera-se uma relação intersubjetiva, no caso do Direito Penal não há um liame de vontade que una imediatamente as partes

\footnotetext{
${ }^{22}$ MONTORO, André Franco. Introdução à Ciência do Direito. Cit. p - 415.

${ }^{23}$ MONTORO, André Franco. Introdução à Ciência do Direito. Cit p - 420.

24 Sinalgma aqui é tratado como reciprocidade de condutas previamente ordenadas para produzirem efeitos recíprocos entre os indivíduos, tal como se dá nos contratos em geral, em que sempre há um liame subjetivo anterior entre as partes contratantes.
} 
envolvidas na relação jurídica prevista. Se o indivíduo comete crime de homicídio, tal ato importa ao Estado, enquanto fiador dos anseios sociais de segurança pública e direito à vida.

Na ação judicial que buscará à condenação do homicida, o pólo ativo da relação processual, ou seja, aquele a quem se confere o direito de requerer a punição estatal é composto pelo próprio Estado, na pessoa do Ministério Público. Aquele que perdeu a vida, ou seus familiares, são meros ofendidos e interessados no deslinde da ação penal com a respectiva condenação do acusado.

Interessante observar também que, à família da vítima de homicídio, restará a composição civil do prejuízo sofrido, que corresponderá às despesas com internação, sepultamento e o que razoavelmente deixarão de ganhar em razão da morte do sujeito, além dos danos morais causados pelo sofrimento da perda violenta de um ente querido.

Percebam que no caso da sanção penal não há sinalagma entre infrator e vítima. Um ato unilateral de vontade acaba por submeter a vontade alheia, que só se manifesta após a prática inadvertida da conduta do outro agente.

Em um crime de roubo, por exemplo, não há um liame subjetivo anterior entre sujeito ativo e sujeito passivo do crime. Na verdade, o sujeito passivo é arrebatado violentamente pelo sujeito ativo e, é justamente para garantir a todos a proteção contra a tomada violenta de seu patrimônio, que o Estado toma a frente da relação e trata diretamente com o autor do crime.

Observa-se nesse ponto a evidente relação de subordinação entre Estado e jurisdicionados, aos quais procura o primeiro conferir igualdade geométrica, distribuindo aos mesmos prêmios e castigos por suas condutas. A reparação do dano, na maioria das vezes inviável (como retornar à vida uma vítima de homicídio?), é substituída pela prevenção geral do crime. Também por isso, a vítima de um crime de roubo, por exemplo, não pode impedir o Estado de processar, julgar e punir o infrator do Código Penal. 
A satisfação do ato infracional é dada a toda a sociedade e a maneira com que os Estados Modernos punem a prática de infrações penais é a segregação do infrator do convívio social com vistas à sua ressocialização, com a exceção dos Estados que adotam a prisão perpétua e a pena de morte como forma de reprimenda dos ilícitos penais.

Bem diferente é a situação do ilícito civil que, para que ocorra necessita de ter havido em momento imediatamente anterior uma relação fiduciária entre partes, com espoliação de direitos por parte de uma delas. Aqui é da relação sinalagmática entre as partes que surge a sanção, aplicável pelo próprio particular que se vê espoliado pela prática da parte contrária.

Na ação judicial que buscará a condenação do devedor de um título de crédito, o pólo passivo da relação processual é o particular ofendido, que provoca o poder judiciário para que diga o seu direito de ingressar no patrimônio do devedor para satisfazer seu direito e retornar as partes ao status quo ante.

A satisfação do ilícito civil é dada ao particular e a maneira com que os Estados Modernos punem a prática de infrações civis é a invasão do patrimônio particular de determinado devedor.

Veja que no caso de ilícito civil o Estado não "senta à mesa" como parte da demanda (como faz no Direito Penal, representado pelo Promotor de Justiça), aparece apenas na figura do juiz, do Poder Judiciário ${ }^{25}$.

\footnotetext{
${ }^{25}$ Exceção feita aos casos em que o Ministério Público intervém em processo civil como custus legis, ou seja, como protetor da lei, ou como curador especial de menores, como no caso de ação de alimentos promovida por um menor contra seu pai. No entanto, a função do Estado aqui será apenas de prestar assistência, velar pelo bom cumprimento da lei.

Distinção interessante para notar a dicotomia entre direito público e privado, por meio da análise do Direito Penal e Civil está nos crimes contra a honra. O Código Penal, ao conferir aos cidadãos o direito de requerer reprimenda penal em razão de calúnia, injúria ou difamação não abre mão de analisar o caso a partir de sua relevância social, aplicando-se a pena quando se vislumbra a necessidade de prevenção geral do crime, por meio da reprimenda penal. Já a satisfação efetiva do dano moral sofrido pela vítima será tratada com base nas normas de direito civil, que cuidarão da sanção pecuniária nessa área.
} 
Pelo que se pôde apurar, parece ser o caso de tratar os ramos direito civil e penal como aqueles que englobam um conjunto de regras que previnem os efeitos civis de determinada conduta e regras que previnem os efeitos penais das condutas, com base nas distinções aqui tratadas, que poderiam ser cotejadas da seguinte forma:

\begin{tabular}{|c|c|c|c|c|c|c|}
\hline & \begin{tabular}{|l} 
Relações \\
intersubjetivas
\end{tabular} & \begin{tabular}{|l|} 
Relações \\
sinalagmáticas
\end{tabular} & \begin{tabular}{|l} 
Estado \\
como \\
Sujeito \\
Passivo \\
da \\
relação \\
jurídica \\
material
\end{tabular} & $\begin{array}{l}\text { Estado } \\
\text { como } \\
\text { Sujeito } \\
\text { Passivo da } \\
\text { relação } \\
\text { jurídica } \\
\text { processual }\end{array}$ & $\begin{array}{l}\text { Sanção } \\
\text { Corpórea }\end{array}$ & $\begin{array}{l}\text { Sanção } \\
\text { pecuniária }\end{array}$ \\
\hline $\begin{array}{l}\text { Direito } \\
\text { civil }\end{array}$ & + & $+/-$ & - & - & - & + \\
\hline $\begin{array}{l}\text { Direito } \\
\text { penal }\end{array}$ & + & $+/-$ & $+/-$ & $+/-$ & + & $+/-$ \\
\hline
\end{tabular}

O traço semântico que aproxima o Direito Civil (como representante do ramo do Direito Privado) do Penal (como representante do ramo do Direito Público) são as relações intersubjetivas que ambos previnem e a distinção entre os ramos do Direito se dá em razão:

Outro fenômeno interessante em direito penal é a figura da representação da vítima ao Ministério Público para que promova ação penal, como no caso de lesões corporais culposas causada em acidente automobilístico, por exemplo. Nesses casos, embora o ofendido tome a iniciativa que impulsiona a persecução criminal, o Ministério Público pode oferecer ao autor do crime os benefícios da lei que possibilitam manter sua primariedade nessa hipótese, por meio do pagamento de multa, de prestação de serviços à sociedade, mas não necessariamente a reparação do dano civil. 
- da preponderância do sinalagma para as normas de direito civil;

- da tutela estatal dos interesses da sociedade nas normas de direito penal;

- na punição corpórea imposta pelo direito penal e pecuniária prevista no direito civil.

Eis um possível caminho para a melhor distinção entre esses ramos do direito, como forma de tratar sob o prisma da análise sêmica a própria dicotomia entre o direito público e privado.

Seria interessante traçar as distinções entre a prática de crime de estelionato e o que a legislação considera mera dívida civil para complexificação da questão aqui suscitada, bem como a análise semântica da zona nebulosa que separa o ilícito penal e o ilícito civil de ordem extracontratual, o que não nos prestaremos a fazer para não nos distanciarmos do objeto central da pesquisa $^{26}$.

Encerrando essa fase de distinções entre ramos do direito, cabe salientar que o direito civil vai estabelecer relações semânticas com outros ramos do direito privado interno, o direito comercial e o direito do trabalho.

No primeiro caso, a distinção se dá em razão do "pano de fundo" da relação, ou seja, no direito civil encontramos normas que tratam da relação entre indivíduos para sua subsistência e no direito comercial temos o feixe de normas jurídicas que estabelecem as relações que visam à circulação e concentração de riqueza.

No segundo caso, dada à especificidade da relação empregatícia, fundamental para o desenvolvimento das atividades produtivas da indústria e comércio e, dada a hipossuficiência do empregado em relação ao possuidor dos meios de produção, a mesma distancia-se das normas gerais de direito civil, ganhando especificidade semântica em virtude da relação obrigacional estabelecida entre partes manifestamente

\footnotetext{
${ }^{26}$ Aqui já começa a se aclarar a limitação da análise componencial como ferramenta para a busca do sentido do discurso em análise. Se, ao que tudo indica, foi providencial para determinar o campo semântico das normas jurídicas, já para se distinguir os ramos de direito, rendeu parcialmente, com uma análise preliminar, a partir de uma hipótese, sujeita a revisões se aplicadas de maneira mais abrangente.
} 
desiguais. Eis uma intervenção estatal nas relações privadas que torna inócua a distinção público/privado do direito. Aqui há concomitância de interesses.

É com esse mesmo raciocínio que na última década do século passado institui-se o chamado Código de Defesa do Consumidor no sistema jurídico pátrio, desmembramento do direito civil, que visa a proteger o consumidor nas relações de consumo em vista de uma presumível fraqueza deste em relação ao fornecedor de bens e serviços.

Podemos ainda aduzir que há traços semânticos que unem o direito do consumidor com o direito do trabalho, qual seja, a hipossuficiência nas relações e relevância pública das trocas humanas, sendo que a oposição é fincada na natureza das relações, a primeira de consumo, a segundo de trabalho e, mais uma vez, ambas intimamente relacionadas com o sistema capitalista de produção de riquezas. Temos aqui mais uma comprovação que a análise da semântica do léxico jurídico pode render interessante releitura das matérias caras à Teoria Geral do Direito.

\subsection{As codificações civis do Brasil - conteúdo}

Isto posto, cumpre esclarecer que o tema em foco aqui é o Direito Civil, tendo como objeto central de nosso estudo as codificações civis do Brasil, em especial o tratamento que conferem aos institutos do casamento civil e da união estável (ou concubinato).

Tanto o Código Civil de 1916 quanto o Código Civil de 2002 abordam os seguintes assuntos:

- Das pessoas: nesta parte, as codificações definem o que se entende por pessoa natural, sua personalidade, seu domicílio bem como o modo de existência das pessoas

jurídicas, ficção criada pelo legislador para conferir direitos e obrigações para uma comunhão de interesses, na forma da lei; 
- Dos bens: depois das pessoas, as codificações partem para a tipificação dos bens passíveis de apreensão pelo homem, uma vez que é entre os homens e seus bens que a codificação civil vai desenvolver seu discurso;

- Dos Fatos Jurídicos: uma vez determinados os homens e seus bens, o direito civil vai tratar das relações intersubjetivas que colocarão em circulação os bens daqueles homens, os requisitos para a validação de suas negociações, seus vícios, os atos ilícitos e o prazo para o exercício dos direitos por quem for lesado;

- Do Direito das Obrigações: ainda atrelado aos negócios jurídicos entre os indivíduos, visto a importância das relações negociais para o direito civil pátrio, os códigos tratam das modalidades das obrigações, seu modo de cumprimento, o adimplemento e inadimplemento das obrigações e seus efeitos, encerrando aí um conjunto de regras que determinam condutas e previnem sanções. Ainda nesta parte da disciplina civil, define-se como os contratos devem ser elaborados, como empresas devem ser constituídas e extintas ${ }^{27}$.

- Direito das Coisas: seguindo o modelo das principais codificações européias, nosso direito civil reconhece e opera a dicotomia entre direito real (das coisas) e direito das obrigações (das pessoas), considerando como critério fundamental de distinção o fato do direito real tratar do poder direto do indivíduo sobre a coisa, importando em três elementos essenciais: a) sujeito ativo da relação jurídica; b) a coisa objeto do direito; c) a inflexão imediata do sujeito ativo sobre a coisa.

- Direito de Família: neste Livro, as codificações civis cuidam da base da sociedade, a família, desde sua gênese até sua dissolução, bem como da questão do

\footnotetext{
${ }^{27}$ A previsão de direito de empresa é inovação do Código Civil de 2002 que, realizando velho projeto de Orlando Gomes (Código das Obrigações), unificou todas as questões que dizem respeito a obrigações assumidas entre indivíduos, incluindo aí a sociedade empresária, revogando inclusive a Primeira Parte do velho Código Comercial do século XIX, ainda que não tenha aniquilado de vez com a distinção que se faz entre direito civil e direito comercial, muito mais como uma reserva de mercado ou luta de egos.
} 
poder familiar, cuidando também do regime de bens que regerá a comunhão matrimonial e os institutos da adoção, tutela e curatela ${ }^{28}$;

- Direito das Sucessões: como as pessoas morrem, mas seus bens não podem deixar de circular, após a morte do sujeito, passam as codificações a tratarem da transmissão de seu patrimônio para terceiros, sejam seus parentes, credores ou o Estado, que não recusará a herança, na hipótese de ninguém mais próximo se habilitar.

Assim, o tema central de nossa análise fica bem definido (direito de família), como ramo do direito civil que cuida das relações afetivas dos indivíduos e suas implicações no campo obrigacional que se abre dentro da família e as considerações sobre o patrimônio, fundamental para gerenciar a vida familiar. Aspectos criminais ou processuais atinentes ao Direito de Família não serão considerados para que não se desvie excessivamente o foco no objeto central.

\subsection{A hierarquia das normas}

Nas linhas acima foram caracterizados os traços semânticos que unem, distinguem e conferem sentido aos signos jurídicos, com base nas lições saussurianas, notadamente na própria noção de signo, polissemia e monossemia e antinomia e heteronomia dos signos. Com isso pudemos contextualizar mais propriamente a posição que ocupa o direito de família no discurso jurídico.

O passo seguinte é determinar como as leis abarcam esses ramos do direito dentro do complexo legislativo estatal para bem posicionar o campo de atuação das codificações civis.

Isso porque as distinções entre os ramos do direito podem até sugerir que haja um conjunto de leis penais, leis civis, leis comerciais, leis trabalhistas, cada qual prevista em legislações absolutamente distintas, o que não ocorre efetivamente.

\footnotetext{
${ }^{28}$ Essa parte das codificações civis, que nos interessa mais de perto, será melhor tratada logo que se fizerem as ponderações necessárias a cerca da hierarquia das normas.
} 
Da análise da legislação pátria, o que se percebe (e do que se viu acima) é que há um sem número de leis que tratam de conferir relevância jurídica a cada um desses ramos do direito e não é a natureza do direito prescrito na legislação que a distingue das demais, mas a sua posição na relação de hierarquia e concorrência entre as normas de determinado ordenamento jurídico.

Uma vez determinada a existência jurídica de um Instituto, quer seja de direito civil, penal, etc., a compreensão de sua relevância legal não se dá pela área do direito a que pertencem, mas da relação que estabelecem as leis que o prevêem com as outras leis que compõem o sistema jurídico de determinada cultura.

Coloquialmente, é comum tratar qualquer tipo de legislação como "lei" em sentido amplo, no entanto, no discurso jurídico, possível se faz visualizar evidente distinção entre os diversos tipos de lei, o que se faz a seguir, para bem se delimitar o campo semântico específico das codificações. Eis mais uma situação de monossemia fruto de construção científica.

Sem maiores delongas e considerações de ordem jurídica, tomemos como premissa que todo ordenamento jurídico se organiza por meio de uma relação de hierarquia e subordinação de normas ou complexos legislativos, sendo que cada nação (ao menos em grande parte) tem a Constituição Federal como complexo legislativo hierarquicamente superior, que trata de distribuir o campo de abrangência do que em direito se entende por leis infra-constitucionais ${ }^{29}$.

Aqui já temos um traço semântico de distinção normativa, que não diz respeito propriamente à matéria tratada, mas sim à posição hierárquica ocupada pela norma: Leis com status constitucional e leis infra-constitucionais.

A Constituição Federal não cuida, como o nome pode fazer presumir, apenas do direito constitucional enquanto ramo do direito, mas também de matérias que dizem

${ }^{29}$ Esta é uma leitura livre dos principais conceitos da obra "Teoria Pura do Direito", de Hans Kelsen. 
respeito ao direito tributário, direito penal, direito civil, direito comercial, direito do trabalho, direito do consumidor.

Assim, se, por um lado, as leis constitucionais são somente aqueles artigos de lei previstos na Constituição Federal de determinado pais, a lei constitucional pode ter como tema os mais diversos ramos do direito. O que é reafirmado para deixar claro que é na relação hierárquica que encontramos o traço semântico distintivo das leis e não o ramo do direito de que tratam.

Compõem as leis infra-constitucionais, em ordem hierárquica, as emendas à Constituição, leis complementares, leis ordinárias, leis delegadas, medidas provisórias, decretos-legislativos, resoluções ${ }^{30}$.

Distinções também são estabelecidas em relação ao ente Federativo emanador da lei, que pode ser a União, os Estados e o Município no sistema federativo pátrio. Quem determina o campo de atuação de cada esfera federativa? A Constituição Federal.

Vale também ressaltar que decretos legislativos e resoluções referem-se ,aos especificamente a procedimentos internos das Casas Legislativas, determinando suas respectivas competência, bem como a recepção de tratados internacionais, etc., fugindo do interesse do nossos estudos, bem como as medidas provisórias e leis delegadas, que só impropriamente podem ser consideradas leis, eis que aqui surge outro traço semântico que distingue esse grupo de normas dos primeiros: terem sido emanadas após a competente tramitação pelas casas que compõem o Poder Legislativo, a quem, na clássica tripartição de poderes, confere-se a atividade precípua de dar vida às leis que ordenam a vida de determinada sociedade ${ }^{31}$.

\footnotetext{
${ }^{30}$ Art. 59 da Constituição Federal/88: "O processo legislativo compreende a elaboração de: I emendas à Constituição; II - leis complementares; III - leis ordinárias; IV - Leis delegadas; V Medidas Provisórias; VI - decretos legislativos; VII - resoluções.

${ }^{31}$ A separação de poderes do Estado em poder executivo, legislativo e judiciário remonta à Política, de Aristóteles, aperfeiçoada por Locke e é tornada definitiva na obra de Montesquieu (“O espírito das Leis”) e, de acordo com tal doutrina, cada poder tem sua função precípua, apenas acidentalmente cumprindo as funções dos demais poderes. No entanto, o que vemos é
} 
Por falar em tramitação pelas Casas Legislativas, é de se destacar que a relação hierárquica estabelecida entre as normas que são da lavra do Poder Legislativo mantém íntima relação com o quorum previsto constitucionalmente e a matéria jurídica que poderão enfrentar. Vejamos cada uma delas:

- emendas à constituição: pretendem alterar o próprio texto constitucional, nos exatos limites de permissão da própria Carta Política do país. A Constituição Federal de 1988, em seu artigo $60, \S 2^{\circ}$ prevê quorum de três quintos dos votos dos membros de cada uma das Casas do Congresso para aprovar tais corpos legislativos, enquanto o $\S 3^{\circ}$ determina que não poderão ser objeto de emenda proposta tendente a abolir a forma federativa de Estado; o voto direto, secreto, universal e periódico; a separação do poderes; os direitos e garantias individuais ${ }^{32}$.

- leis complementares: previstas no parágrafo único do Art. 59 ${ }^{33}$, a lei complementar só tem cabimento nas situações específicas em que o texto constitucional

um sem-número de medidas provisórias que ditam pontualmente o destino do Estado, acabando por, na prática, o Chefe do Executivo (o Presidente da República) tornar-se o editor de leis.

${ }^{32}$ Art. 60 (CF/88): “A Constituição poderá ser emendada mediante proposta: I - de um terço, no mínimo, dos membros da Câmara dos Deputados ou do Senado Federal; II - do Presidente da República; III - de mais da metade das Assembléias Legislativas das unidades da Federação, manifestando-se, cada uma delas, pela maioria relativa de seus membros. $\S 1^{\circ}$ A Constituição não poderá ser emendada na vigência de intervenção federal, de estado de defesa ou de estado de sítio. $\S 2^{\circ}$ A proposta será discutida e votada em cada Casa do Congresso Nacional, em dois turnos, considerada aprovada se obtiver, em ambos, três quintos dos votos dos respectivos membros. $\S 3^{\circ} \mathrm{A}$ emenda à constituição será promulgada pelas Mesas da Câmara dos Deputados e do Senado Federal, com o respectivo número de ordem. $\S 4^{\circ}$ Não será objeto de deliberação a proposta de emenda tendente a abolir: I - a forma federativa de Estado; II - o voto direto, secreto, universal e periódico; III - a separação de poderes; IV - os direitos e garantias individuais. $\S 5^{\circ}$ A matéria constante de proposta de emenda rejeitada ou havida por prejudicada não pode ser objeto de nova proposta na mesma sessão legislativa.

33 Art. 59, parágrafo único (CF/88): Lei complementar disporá sobre a elaboração, redação, alteração e consolidação das leis. 
determina que a matéria será regulamentada por lei complementar ${ }^{34}$. Veja, que a lei complementar não altera a Constituição, apenas torna efetivo um expresso comando constitucional. O quorum previsto é o qualificado, em cada uma das Casas do Congresso Nacional para sua aprovação, nos termos do art. $69^{35}$ da Constituição Federal.

- leis ordinárias: como o próprio nome sugere, são as leis comuns de um Estado, em oposição às leis que possuem caracteres especiais, tais como as leis constitucionais, as emendas à constituição e as leis complementares. Tratam de qualquer tipo de matéria (desde que de encontro com os anseios constitucionais) e exigem apenas maioria simples para sua aprovação (art. $47 \mathrm{CF} / 88^{36}$ ).

Aqui já fica demais evidente o traço semântico de oposição proposto para o estudo das normas: a hierarquia e limitação e alcance da matéria que trata.

Hierarquia implica relações de subordinação entre os elementos, sendo certo que o elemento hierarquicamente superior determina a atribuição do elemento hierarquicamente inferior, que àquele deve obediência.

Assim, por esses traços semânticos, distinguimos uma lei das outras por meio do poder que possuem de conferirem validade e vigência às leis que a ela se subordinam. Explica-se:

Uma lei constitucional não perde sua vigência por determinação de lei infraconstitucional. A lei complementar não pode ser revogada por lei ordinária. Lei ordinária, além de não poder revogar lei complementar, pode por essa e por emendas à constituição ser revogada.

\footnotetext{
${ }^{34}$ Podemos citar como exemplo o expresso no art. 93 da CF/88: "Lei complementar, de iniciativa do Supremo Tribunal Federal, disporá sobre o Estatuto da Magistratura, observados os seguintes princípios $(\ldots) "$

${ }^{35}$ Art. 69 (CF/88): "As leis complementares serão aprovadas por maioria absoluta."

${ }^{36}$ Asrt. 47 (CF/88): "Salvo disposição constitucional em contrário, as deliberações de cada Casa e de suas Comissões serão tomadas por maioria de votos, presente a maioria absoluta de seus membros.
} 
Quanto ao quorum, a lei ordinária é aprovada por maioria de votos, quando presente a maioria dos membros da Casa Legislativa. Ressalta-se aqui o outro traço semântico que vimos apontando, das formalidades para a promulgação de lei.

Veja que, enquanto a emenda à constituição exige quorum especial e a lei complementar exige quorum qualificado, a lei ordinária adquire validade por mera maioria de votos, com a participação da maioria dos parlamentares.

Assim, quanto mais superior hierarquicamente a norma, maior o revestimento de formalidades para sua entrada em vigência, em razão mesmo da sua maior relevância para o sistema jurídico.

Considerando que cada membro da Assembléia Legislativa é um representante do povo, quanto maior a posição hierárquica da norma, maior a exigência de consenso entre os representantes dos mais diversos anseios do povo, até chegarmos à Constituição, cujas diretrizes de todo um sistema jurídico é franqueada pelo o que se convenciona denominar em direito de poder constituinte originário, ou seja, aquele poder que edita a Constituição nova substituindo a constituição anterior, o que deixa claro que essas normas não devem obediência hierárquica a nenhuma outra.

Propomos o seguinte quadro de cotejo de traços semânticos para a análise das normas jurídicas:

\begin{tabular}{|l|l|l|l|}
\hline & Quorum & $\begin{array}{l}\text { Matéria } \\
\text { Constitucional }\end{array}$ & Subordinação \\
\hline Lei constitucional & - (poder originário) & + & - (poder originário) \\
\hline Emendas & + (especial) & + & $+($ à CF) \\
\hline Lei complementar & + (qualificado) & $\begin{array}{l}-(\text { infra / se previsto } \\
\text { na CF) }\end{array}$ & $+(a ̀ C F)$ \\
\hline Lei ordinária & + (simples) & $\begin{array}{l}\text { (infra / conteúdo } \\
\text { livre) }\end{array}$ & $\begin{array}{l}+ \text { (à CF, emendas e } \\
\text { leis } \\
\text { complementares })\end{array}$ \\
\hline
\end{tabular}




\subsection{As codificações civis na hierarquia das normas}

Dentro do campo das leis ordinárias, encontram-se, afinal, o complexo de normas jurídicas que pretendemos analisar: as codificações. Assim temos que dentro do que se convencionou denominar no discurso jurídico por leis ordinárias, as codificações ocupam papel de relevo, enquanto conjunto de normas norteadoras de determinado campo do direito.

É tradição que acompanha os povos, desde o período romano, reunir os grandes ramos de conhecimento em codificações, com o intuito de conferir sentido de solidez das normas do Estado, afastando-se do direito baseado nos costumes de determinada nação ${ }^{37}$.

É assim que o nosso ordenamento jurídico recepciona o Código Tributário Nacional, O Código de Processo Civil, o Código de Processo Penal, o Código Penal, o Código Comercial e o Código Civil.

${ }^{37}$ Como bem explica VENOSA, Sílvio de Salvo. "Novo Código Civil”. $3^{\mathrm{a}}$ Edição. Editora Atlas-Jurídico. 2003. p. 19.: “A codificação moderna é um dos espetaculares efeitos alcançados pela escola do Direito Natural. A questão era por que razão converter em direito positivo aquele direito ensinado nas universidades, um direito que já se apresentava ordenado, pesquisado e que fora direito positivo no passado, ou seja, o velho Direito Romano. Pretendeu-se transformar em direito real algo que na época era direito ideal. A escola do Direito Natural permitirá realizar essa ambição. No século XVIII, a codificação permitirá também, pela intervenção do legislador, acabar com o arcaísmo que impedia o progresso do direito, preso então a multiplicidade de costumes. Nisso a codificação se distingue das consolidações, que apenas se limita a colocar lado a lado as normas então vigentes. 
Quanto ao Código Civil, que nos interessa mais de perto, vejamos qual a sua relação com as leis hierarquicamente superiores a ele e com as leis esparsas de origem ordinária também.

A primeira codificação civil brasileira entrou em vigência em 1917, sob a égide da Constituição Federal de 1891. Ao longo de seus 86 anos de vigência esta codificação sofreu alterações em razão da entrada em vigor de legislações hierarquicamente superiores, ou seja, as Constituições Federais de 1934, 1946, 1967, 1969 e 1988; e de leis ordinárias esparsas que, só para ficar no ramo do direito de família e citando as mais importantes, temos:

- Lei 883, de 21 de outubro de 1949 (dispõe sobre o reconhecimento dos filhos ilegítimos);

- Lei 1.110 de 23 de maio de 1950 (regula os efeitos civis do casamento religioso);

- Lei 4.121 de 27 de agosto de 1962 (conhecido como Estatuto da mulher casada);

- Lei 5.478 de 25 de julho de 1968 (dispõe sobre ação de alimentos e dá outras providências);

- Lei 6.515 de 26 de dezembro de 1977 (dispõe sobre dissolução de sociedade conjugal e do casamento, seus efeitos e respectivos processos);

- Lei 8.069 de 13 de julho de 1990 (dispõe sobre o Estatuto da Criança e Adolescente);

- Lei 8.560 de 29 de dezembro de 1992 (dispõe sobre investigação de paternidade dos filhos havidos fora do casamento);

- Lei 8.971 de 29 de dezembro de 1994 (regula o direito dos companheiros a alimentos e à sucessão);

- Lei 9.278 de 10 de maio de 1996 (regulamenta o parágrafo $3^{\circ}$ do art. 226 da Constituição Federal de 1988, que trata da união estável).

Com isso, desfigurou-se sobremaneira o conteúdo do primitivo texto do Código de 1916, sobretudo pelo advento de leis esparsas, ferramentas menos complexas do legislador para adequar a lei aos anseios sociais, uma vez que tratam de um tema 
pontualmente, como se pode notar pela leitura das matérias tratadas pelas legislações esparsas acima numeradas.

E, não se pode perder de vista que a Constituição Federal de 1988 sugere uma alteração da codificação civil ao determinar, em seu art. $226, \S 3^{\circ}$, a união estável como entidade familiar ${ }^{38}$.

Esse é justamente o caso que trataremos nessa dissertação, que é o direito de família, mais especificamente o casamento civil e a união estável. Foi por meio da recepção de referido instituto pela Constituição Federal de 1988 que se cessaram os embates jurisprudenciais sobre os direitos recíprocos entre os conviventes.

Em razão da inexistência de previsão expressa na codificação civil de 1916 sobre o tema, leis ordinárias esparsas foram criadas para regrá-lo, sem, contudo, operarem transformações no Código Civil, apenas ampliando o alcance semântico do direito de família.

Vejamos mais de perto os preceitos de uma dessas leis.

LEI N 9.278, DE 10 DE MAIO DE 1996.

Regula o $\S 3^{\circ}$ do art. 226 da Constituição Federal.

O PRESIDENTE DA REPÚBLICA, faço saber que o Congresso Nacional decreta e eu sanciono a seguinte Lei:

Art. $1^{o}$ É reconhecida como entidade familiar a convivência duradoura, pública e continua de um homem e uma mulher, estabelecida com objetivo de constituição de família.

Art. $2^{\circ}$ São direitos e deveres iguais dos conviventes:

I - respeito e consideração mútuos; 
II - assistência moral e material recíproca;

III - guarda, sustento e educação dos filhos comuns.

Art. $3^{\circ}($ VETADO)

Art. $4^{\circ}$ (VETADO)

Art. $5^{\circ}$ Os bens móveis e imóveis adquiridos por um ou por ambos os conviventes, na constância da união estável e a título oneroso, são consideradas fruto do trabalho e da colaboração comum, passando a pertencer a ambos, em condomínio e em partes iguais, salvo estipulação contrária em contrato escrito.

$\S 1^{\circ}$ Cessa a presunção do caput deste artigo se a aquisição patrimonial ocorrer com o produto de bens adquiridos anteriormente ao início da união.

$\S 2^{\circ}$ administração do patrimônio comum dos conviventes compete a ambos, salvo estipulação contrária em contrato escrito.

Art. $6^{\circ}$ (VETADO)

Art. $7^{\circ}$ Dissolvida a união estável por rescisão, a assistência material prevista nesta Lei será prestada por um dos conviventes ao que dela necessitar, a título de alimentos.

Parágrafo único. Dissolvida a união estável por morte de um dos conviventes, o sobrevivente terá direito real de habitação, enquanto viver ou não constituir nova união ou casamento, relativamente ao imóvel destinado à residência da família.

Art. $8^{\circ}$ Os conviventes poderão, de comum acordo e a qualquer tempo, requerer a conversão da união estável em casamento, por

${ }^{38}$ Art. 226, $\S 3^{\circ} \mathrm{Da} \mathrm{CF} / 88$ : "Para efeito da proteção do Estado, é reconhecida a união estável entre o homem e a mulher como entidade familiar, devendo a lei facilitar sua conversão em casamento." 
requerimento ao Oficial do Registro Civil da Circunscrição de seu domicílio.

Art. $9^{\circ}$ Toda a matéria relativa à união estável é de competência do juízo da Vara de Família, assegurado o segredo de justiça.

Art. 10. Esta Lei entra em vigor na data de sua publicação.

Art. 11 Revogam-se as disposições em contrário.

Brasília, 10 de maio de 1996; $175^{\circ}$ da Independência e $108^{\circ}$ da República.

\section{FERNANDO HENRIQUE CARDOSO}

Milton Seligman

Como se pode notar, as leis esparsas tratam pontualmente de determinado tema de relevância jurídica, todos os demais temas correlatos ao ali tratado fazem remissão a textos de outras leis, que podem ser a Constituição Federal, à qual buscam conferir efetividade e à própria codificação civil, que visam a alterar.

Mais uma vez resta evidente a relação hierárquica entre as normas: lei ordinária esparsa que não altera o texto constitucional, mas que amplia os conceitos do Código Civil alterando-o.

Também dessa análise é possível traçar um elemento semântico de distinção entre as codificações e leis esparsas: as primeiras são mais rígidas e amplas, buscam à uniformização de mecanismos de um determinado ramo do direito. Voltaremos a essas reflexões no último capítulo da dissertação.

\section{Casamento, união estável e concubinato no dicionário}


Após uma prévia e superficial análise componencial de termos mais abrangentes que formam o discurso jurídico, tais como o significado de norma jurídica, direito civil, legislação, passemos a analisar, sob o mesmo enfoque, relação mais específica e de maneira mais detida, procurando ser fiel às bases lingüísticas da pesquisa. Conforme se demonstrará, referida análise prévia será de grande utilidade para as conclusões alcançadas ao longo dessa dissertação.

Optamos, dentro dos estudos de direito civil, pelo direito de família muito em razão de ser instituto jurídico que guarda íntima relação com o cotidiano dos indivíduos, que mantém proximidade com a moralidade média de um povo, seja no aspecto social ou religioso.

É curioso notar a preocupação social em torno do enlace entre duas pessoas é passível de gerar graves embates familiares, notícias ao pé do ouvido na vizinhança, desconforto em eventos sociais, constrangimento para os filhos, havendo sempre uma resposta social ao modo de agir em família.

Falar em relações familiares é falar sobre o estado civil das pessoas. Qualquer documento que assinamos pergunta se somos solteiros, casados, divorciados, viúvos ou, até mesmo amancebados. O estado civil já diz algo sobre o indivíduo.

Ser solteiro pode significar "um jovem em busca de seu amor verdadeiro", ou um rapagão que "gosta de viver a vida", ou uma moça que já "ficou para a titia".

Ser viúvo significa ter perdido "a pessoa com quem conviveu por longos anos", no caso de um ancião, o que lhe confere condolências por parte da sociedade e gestos de ternura; fosse uma jovem vistosa com 22 anos de idade poderia significar "golpe do baú".

Ser casado é sinal de correção, daquele que assume publicamente seus atos, arcando com suas obrigações de bom homem médio; pode significar também mero 
enlace de conveniência, na hipótese de um casal que raramente é visto junto, ainda mais se não usam as alianças dos esponsais.

A mulher que em um condomínio recebe com freqüência em sua residência um senhor mais velho, que permanece lá por algumas horas, mas que raramente pernoita, certamente é considerada pelos demais condôminos como "amásia", "amante", “amancebada", se não como "mulher de vida fácil” ou "pecadora".

Aquele que não contraiu núpcias celebrando casamento diante de um dos padres da Igreja Católica não pertence à paróquia, senão como cidadão de hábitos profanos, que não edificou sua união conjugal com a benção do Espírito Santo. As carolas saberão disso.

Com esses comentários até mesmo jocosos, queremos dizer que as relações familiares são muito mais que um instituto jurídico que tenta, de maneira por vezes desajeitada, apressada mesmo, conferir revestimento de juridicidade a estas relações humanas que atormentam homens e mulheres desde quando o mundo é mundo, quando a noção de direito sequer pairava pelos ares. Aqui moralidade e direito guardam estreitas relações.

Além disso, sob o enfoque lingüístico já se pode constatar, ainda que exposto de maneira descontraída, que o significado dos signos dependem muito do uso discursivo que determina o efetivo sentido do signo de acordo com o contexto. Eis aí a evidência da polissemia dos termos, os quais o direito vai tratar, por meio de sua rede de relações, de tornar monossêmicos.

Permanecendo nas relações conjugais e, antes de ingressarmos no discurso jurídico, partindo do pressuposto de que os dicionários de uma determinada língua conferem o sentido conotado dos signos, mas sem perder de vista que são, por excelência, expressões de ideologia de uma nação, vejamos a definição que apresentam de casamento e concubinato. 
Houaiss

Casamento - Ato ou efeito de casar; vínculo conjugal entre um homem e mulher; juridicamente - união voluntária de um homem e uma mulher nas condições sancionadas pelo direito, de modo que se estabeleça uma família legítima.

Concubinato - entre os antigos romanos, união conjugal autorizada entre cidadãos não romanos. No baixo Império, casamento legal, mas estatuto considerado inferior. Juridicamente - união livre e estável de um homem e uma mulher que não são casados um com o outro; amásia.

Dicionário Virtual Rideel casamento

s. f., união legítima entre homem e mulher; enlace; matrimônio; consórcio; núpcias.

Concubinato: do Lat. Concubinatu s. m., estado de mancebia; diz-se da situação em que duas pessoas vivem maritalmente sem serem casadas.

Mancebia: s. f., estado de quem vive amancebado; concubinato; vida dissoluta; $a$ juventude, os mancebos.

Dicionário Escolar da Língua Portuguesa

Casamento: s.m. união legítima entre homem e mulher; núpcias, enlace, matrimônio, bodas.

Concubinato: s.m. vida de amante

Amante: adj. e s. 2 gên. Que ama; namorado ou namorada que mantém ligação ilícita (fem.: amásia).

Esclareça-se que consideramos lexemas uma entrada de dicionário, tais como "casamento" e "concubinato". Para concubinato, trazemos também o lexema "mancebia", que completa o sentido do signo. 
Da simples confrontação dos semas observamos a validade das lições de Saussure, uma vez que claramente, o segundo significado de "concubinato" só se faz possível na oposição que estabelece com o signo "casamento": “diz-se da situação em que duas pessoas vivem maritalmente sem serem casadas". "Casadas" é qualidade de quem contraiu núpcias, casou-se, o que remete para o signo "casamento". É somente na oposição com o signo casamento que a segunda definição de concubinato faz sentido.

Também é possível notar o traço semântico que aproxima os termos: enlace afetivo, amoroso, "união amorosa entre pessoas". Esse traço semântico também é compartilhado pela primeira definição de concubinato do dicionário virtual, uma vez que mancebia sugere uma amizade íntima, de cunho amoroso: quando se fala em “amizade”, fala-se em "boas relações", união.

Tanto a definição de casamento quanto a segunda definição de concubinato sugerem uma união contínua entre pessoas. No primeiro caso, o sema "consórcio" significa "comunhão de interesses", deixando claro que o casamento é a união amorosa entre pessoas com o fito de permanecerem unidas com um mesmo interesse. Qual esse interesse? Permanecer em união, para constituir uma família.

Temos aí a idéia de "estado", de permanência, de "continuação da continuação". E é isso o que é realmente o casamento, uma relação amorosa permanente entre homem e mulher, com vistas a dar vida a um interesse comum.

Já a segunda definição de concubinato do dicionário Rideel faz clara referência ao casamento ao afirmar que se trata de relação entre pessoas que convivem como se casadas fossem, ou seja, com a intenção de permanecerem em estado de união, de constituir família.

Já a primeira definição de concubinato desse mesmo dicionário refere-se a "estado de mancebia", que sugere também permanência, mas também referente à "vida dissoluta," que em sentido denotado significa "dissolvido", "desfeito" e figurativamente 
significa "devasso", “corrupto". Nesse caso, não se observa o traço da união para constituir família, dado ao seu caráter dissoluto, espúrio.

Viver amancebado é viver um amor marginal, com objetivos meramente carnais, visando a relação amorosa em si mesmo, sem intenção de constituir família, o que não seria possível em razão de seu caráter sub-reptício.

Aqui começa a aclarar uma questão importante: os semas que compõem o lexema "casamento" opõem-se claramente aos semas que compõem a primeira definição do lexema "concubinato", eis que apresentam uma distinção evidente: a finalidade de constituir família.

\begin{tabular}{|l|l|l|l|l|}
\hline & União duradoura & $\begin{array}{l}\text { Intenção de } \\
\text { constituir família }\end{array}$ & União Pública & Ato solene \\
\hline Casamento & + & + & + & + \\
\hline Concubinato & + & - & - & - \\
\hline
\end{tabular}

Esses signos podem ser tratados também por meio de uma oposição fundamental de termos, tal como concebido em semiótica. Considerando-se o "casamento" e o "concubinato" como formas possíveis de relacionamento entre pessoas, o primeiro termo é investido do traço semântico fundamental /Integração/ às normas sociais em geral, quer jurídicas, quer sociais, ao passo que o segundo termo relaciona-se com os valores de /Transgressão/ às normas sociais em geral.

Por essa via, temos que o "casamento" e o "concubinato" guardam entre si distinções desde o nível fundamental do discurso, dos quais são a tematização, ou seja, aquilo que se exterioriza prima facie do texto.

INTEGRAÇÃO

(casamento)
TRANSGRESSÃO

(concubinato) 


\section{N TRANSG N INTEGR}

Assim, por meio do percurso norteado pelos valores de /integração/, o sujeito, quer por auto-manipulação, quer por manipulação social, persegue a celebração do casamento e semeadura dos laços familiares que daí advirá, sendo sancionado positivamente por seu ato.

Propondo-se a uma vida concubinária, o sujeito manipulado por paixões espúrias é levado a agir em percurso contrário ao proposto pelo sujeito sancionador, que é a sociedade, e assim, ao euforizar os valores de /transgressão/ é sancionado negativamente, sofrendo segregação social.

Não é bem esse o caso da segunda definição de concubinato que apresentamos. Com efeito, o que se depreende é a intenção de "viverem como se casados fossem", ou seja, há uma intenção de entrar em conjunção com os valores de /Integração/, o que não ocorre em razão de algum empecilho que impede a realização da performance pretendida.

A segunda definição de união estável é, portanto a /não transgressão/, o estado do sujeito que quer-ser, mas que não tem competência para tanto. Vale dizer, ele quer ser reconhecido como integrado aos valores sociais, afastando-se dos valores de /transgressão/ adotados pelos concubinos impuros. E o que lhe falta para atender a seus propósitos de /integração/ social? Reconhecimento jurídico de seu estado. Voltaremos a isso.

Antes, cabe concluir, sob a perspectiva da análise componencial iniciada, que a segunda definição do termo concubinato apresenta nítida distinção da primeira definição, sendo certo que se aproxima mais da noção de casamento do que de concubinato espúrio. Certamente o dicionário pesquisado não levou em consideração o conceito de união estável, embora tenha traçado nítida distinção sêmica entre as duas definiç̧ões. 
É porque, como já alertado, o dicionário é expressão da ideologia de um povo e, socialmente realmente é nítida a distinção que se faz entre os indivíduos que vivem em concubinato espúrio e a assim chamada união estável.

União estável não pode ser compreendida como concubinato impuro, eis que busca disforizar o valor de /transgressão/ que carrega aquela união amorosa. Também não pode ser o mero namoro, o que, na oposição entre /trangressão/ e /integração/ é o termo neutro, um início de enlace que nega os dois valores, eis que ainda distante deles.

Tão pouco pode ser noivado, uma vez que noivado sugere transformação e não estado e ainda confere a qualidade daquele que ainda não se casou, mas que possui competência para tanto (art. 1525 do novo Código Civil ${ }^{39}$ ).

Não sendo sinônimo de nenhum desses termos, surge a relevância de criar um signo para a união daqueles que convivem como se casados fossem, mas que padecem de legitimidade para entrar em conjunção com seu objeto-valor, que é a união legítima.

Não se confere à União Estável o estatuto de união legal, pois, ao contrário do casamento civil, não é previamente regulado por lei, mas o que de fato ocorre é que a Lei confere status de entidade familiar à união entre homem e mulher que preenchem os requisitos legais, conforme se verá mais adiante.

Esclareça-se que, por hora, as oposições semânticas estão considerando regras sociais em sentido amplo, sendo que o revestimento jurídico só é relevante para demarcar o traço característico da legitimidade ou intenção de legitimidade da conduta daqueles que se envolvem nessas espécies de união afetiva.

Assim, preliminarmente, admitindo ainda no campo social a distinção entre concubinato impuro e união estável, podemos incluir esse último signo no léxico, propondo o seguinte quadro de traços semânticos:

\footnotetext{
${ }^{39}$ Art. 1525 do Código Civil: “O requerimento de habilitação para o casamento será firmado por ambos os nubentes, de próprio punho, ou, a seu pedido, por procurador,e deve ser instruído com os seguintes documentos: (...)”. Da leitura do texto de lei, depreende-se o conceito de nubentes, ou seja, os noivos, aqueles que namoram com a intenção de casarem-se futuramente.
} 


\begin{tabular}{|l|l|lr|l|l|}
\hline & União duradoura & $\begin{array}{l}\text { Intenção de } \\
\text { constituir família }\end{array}$ & União Pública & Ato Solene \\
\hline Casamento & + & + & + & + \\
\hline União estável & + & + & + & - \\
\hline Concubinato & + & - & - & - \\
\hline
\end{tabular}




\section{CAPÍTULO 2 - SEMIÓTICA GREIMASIANA E O DISCURSO JURÍDICO}

De início, o estudo aqui pretendido enfrenta uma questão terminológica: será o caso de se determinar a existência de uma semiótica jurídica propriamente dita, da mesma forma que se acostumou a estudar uma filosofia do direito, destacada da filosofia geral? Ou, se é o caso de simplesmente adaptar a teoria semiótica para o estudo do discurso do direito, adequando seus pressupostos às peculiaridades deste tipo discursivo?

Talvez, antes de adentrar nesta questão deveras tormentosa - que já rendeu muito debate no ramo da Filosofia -, seja o caso de começar a investigação pretendida de maneira cuidadosa e, a princípio, esclarecer o que se entende pela teoria semiótica explorada nos estritos âmbitos desta dissertação e enumerar o que já foi produzido neste sentido pelos renomados autores da área científica a ser explorada.

$\mathrm{Na}$ área jurídica, a denominação "semiótica" como teoria exegética, longe de ser desconhecida, é amplamente difundida e referenciada, notadamente em sua faceta semiológica, ou seja, como "Teoria do Signo”.

A nós, é preferível explorar os conceitos da semiótica de linha francesa, desenvolvida a partir dos estudos de A. J. Greimas e a teoria da qual foi o precursor e que continua a ser desenvolvida ${ }^{40}$.

${ }^{40}$ A esse respeito, cita-se a lição de BERTRND, Denis, "Caminhos da Semiótica Literária". Edusc. 2003. p. 13-14: "Consideremos agora uma outra definição de semiótica, no mesmo dicionário Petit Robert. Ela é dupla: 'Teoria geral dos signos e de sua articulação de pensamento (= lógica). Teoria dos signos e do sentido, e de sua circulação na sociedade (= semiologia).' Cada uma dessas definições delinea um campo de duas concepções distintas da semiótica, que estão na origem de duas grandes tradições e que nos limitaremos a localizar: a semiótica americana e a semiótica européia. A primeira, fundamentada na obra do filósofo e lógico Charles Sanders Peirce (1839-1914), atém-se especialmente ao modo de produção do signo (os 
Para servir de colaboração para os estudos desta linha teórica, o presente estudo não se presta a submergir às bases da semiótica geral - seja no campo da lingüística, sua ciência mãe, seja no levantamento do que historicamente foi produzido na área -, mas apontar seus possíveis desenvolvimentos quando destinados ao estudo do discurso jurídico.

Para este ramo do conhecimento, contamos com dois estudos básicos e fundamentais que servem de amparo e guia para os estudos semióticos do discurso jurídico que, até pouco tempo, rareavam, a não ser quando confusa e temerariamente incluídos em estudos semióticos "lato sensu", que não viam problemas em conciliar teorias semióticas, em regra inconciliáveis, para explicar o fenômeno jurídico enquanto auxiliares hermenêuticos.

Para melhor compreensão, cabe esclarecer as bases gerais da semiótica a ser explorada.

\section{Modelo greimasiano}

O Objeto da semiótica é o sentido. O modelo proposto por Greimas visa a analisar qualquer texto por meio das oposições internas estabelecidas em níveis distintos que se relacionam e mantêm entre si relações de hierarquia e pressuposição lógica.

esquemas inferenciais do raciocínio: dedução, indução, abdução) e à sua relação com a realidade referencial pela mediação do 'interpelante' (de onde provém a tipologia dos signos: ícone, índice, símbolo). É uma semiótica lógica e cognitiva, desvinculada de qualquer ancoragem nas formas linguageiras. A segunda, ao contrário, tem suas raízes na teoria da linguagem, mostrando assim a sua filiação a Saussure, seus postulados estruturais e sua concepção da língua como instituição social; é essa semiótica, cujos principais modelos de análise são de origem lingüística, que vamos desenvolver aqui. Ela é, às vezes, conhecida pelo nome "Escola de Paris"” É justamente essa segunda linha de semiótica que desenvolvemos aqui nesse trabalho, em contraposição aos estudos de semiótica de linha pierciana aplicados ao Direito. 
É assim que o sentido forma-se partindo das camadas mais profundas e abstratas e chegando às mais superficiais e concretas, sendo certo que a geração do sentido pode ser observada seja qual for o caminho eleito para análise.

O percurso de geração de sentido dos textos está baseado na distribuição dos seguintes níveis: nível fundamental, o mais profundo que gerencia as relações de oposições fundamentais que fundam os textos; o nível narrativo que articula as transformações de estado e as relações entre sujeito e objeto-valor contidas nos textos e o nível discursivo em que as relações estabelecidas nos níveis mais profundos "ganham" a superfície do texto, representadas por temas e figuras.

Cada um dos níveis sustenta-se em uma construção sintáxica e uma construção semântica. A sintaxe ${ }^{41}$ é responsável por determinar a estrutura de encadeamentos do texto, que torna possível a apreensão do sentido que desvela, em nível transfrasal, ou seja, considerando o discurso como um todo.

Já a semântica é responsável por carregar com significação própria os valores que se encontram nos textos, de acordo com as opções ideológicas tomadas pelo enunciador para a produção de sentido.

A camada mais profunda de organização de um texto é o nível fundamental, constituído por uma rede fundamental de relações fundadas em oposições semânticas. Para se oporem duas categorias semânticas fundamentais, ambas devem possuir um traço que as aproxime, daí a validade dos estudos de lingüísticas para a compreensão do aparato semiótico.

É assim que opomos/masculinidade/vs/feminilidade/, uma vez que ambas possuem o traço /sexualidade/ em comum, da mesma forma que opomos /vida/vs/morte/, /natureza/vs/cultura/, por possuírem, da mesma forma, traço semântico semelhante ${ }^{42}$.

\footnotetext{
${ }^{41}$ GREIMAS, A.J., COURTÉS, J. Dicionário de Semiótica. Cultrix. 1979., p. 430, entrada 2).

${ }^{42}$ FIORIN, José Luiz. Elementos de Análise do Discurso. Editora Contesto-linguística. 2001. p. 19.
} 
Não há um inventário exaustivo das possíveis oposições semânticas do nível fundamental. $\mathrm{O}$ que se deve ter em mente para elegê-las, além dos sinais que nos são fornecidos pelo texto, uma vez que o método é hipotético-dedutivo, é sua condição de oposição de termos suficientemente abstratos a ponto de estarem presentes na base de uma infinidade de textos das mais diversas ordens.

É assim que uma pintura, um romance e um filme podem apresentar a mesma oposição fundamental /natureza/vs/cultura/. Imagine uma pintura em que se vê uma grande casa cercada de vegetação, animais e um trem passando ao fundo. Pode-se relacionar a casa e o trem pelo traço /cultura/ que têm em comum, da mesma forma que se pode relacionar a vegetação e os animais pelo traço /natureza/ em comum. Ambos termos são opostos entre $\mathrm{si}^{43}$.

Imagine agora um romance em que se conta a história de um executivo ganancioso que vive em uma grande cidade, que valoriza os bens materiais e que vai para uma pequena fazenda no interior e lá encontra um grande amor, entre arbustos e banhos de lagoa. Aqui também o que se observa é uma oposição entre /cultura/ e /natureza/ ${ }^{44}$.

Finalmente, em um filme infantil como "Madagascar", por exemplo, em que animais de um zoológico de Nova York acabam indo parar em uma ilha paradisíaca, esses animais participam de uma história em que se opõe /cultura/ (Nova York, alimento em fartura) e /natureza/ (Madagascar, luta pela sobrevivência) ${ }^{45}$.

\footnotetext{
${ }^{43}$ Textos não-verbais, como são exemplo os textos pictóricos, são analisados em profundidade por meio do desenvolvimento dos estudos sobre sistemas semi-simbólicos de semiótica visual.

${ }^{44}$ Textos literários recebem especial atenção dos semioticistas, sendo que a base de estudos de qualquer linha de abordagem de linha semiótica, esbarra na necessidade de leitura e compreensão de textos de semiótica literária, como é o exemplo da obra citada de Denis Bertrand que nos vem servindo de suporte.

${ }^{45}$ Textos em que há várias formas de expressão que regem um mesmo conteúdo, ou seja, um mesmo todo de sentido para o texto que se cria por meio de sua interação, são estudados em semiótica como sincréticos, que dão origem a notáveis ensaios semióticos.
} 
Por sua vez, a sintaxe do nível fundamental para estabelecer a organização de encadeamento de base do texto, coteja os termos semânticos opostos e estabelece como se dará a relação tímica, ou seja, qual termo é carregado positivamente (euforizado) e qual termo é carregado negativamente, disforizado ${ }^{46}$.

No exemplo do parágrafo anterior, ao chegarem à ilha de Madagascar, os animais ficam maravilhados com a liberdade e as belezas do mundo natural, estão euforizando a natureza, com a qual querem estar em conjunção; quando percebem que não podem ser amigos na natureza, eis que um deles é um leão e os demais são animais que, em regra, são suas presas e fonte de matéria e energia para ele na natureza, passam a negar a /natureza/, com a qual querem entrar em estado de disjunção, para finalmente, entrar em conjunção com a /cultura/, que passa a ser o termo eufórico.

As relações aqui estabelecidas podem ser analisadas por meio de um esquema semiótico, definido como quadrado semiótico ${ }^{47}$ :

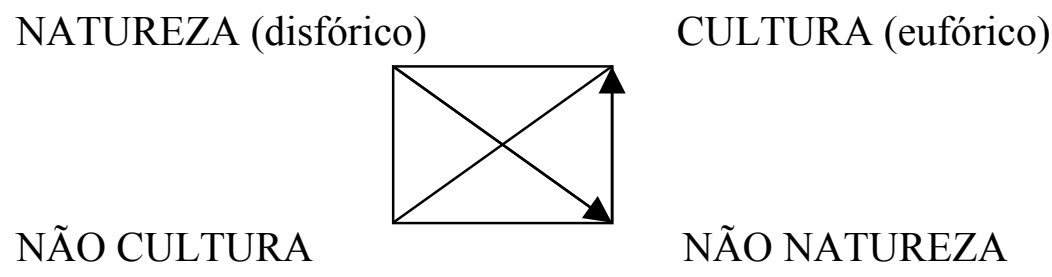

\footnotetext{
46 A esse respeito, segue definição esclarecedora do signo "tímica" encontrada no já citado "Dicionário de Semiótica" (p. 463), após uma intrincada definição do termo timia: "A categoria tímica articula-se, por sua vez, em euforia/disforia (tendo aforia como termo neutro) e desempenha um papel fundamental na transformação dos microuniversos* em axiologias: conotando como eufórica uma dêixis* do quadrado* semiótico e como disfórica a dêixis oposta, ela provoca a valorização positiva e/ou negativa de cada um dos termos da estrutura* elementar da significação."

${ }^{47}$ GREIMAS, AJ/COURTÉS, J.). Dicionário de semiótica. Cit.p. 365/366.
} 
Uma vez determinada a rede fundamental de relações que fundam o texto, é preciso analisar agora como são articuladas no nível narrativo, quando sujeitos se relacionam com objetos conferindo-lhes valores, atualizando as oposições fundamentais, operando transformações de estado.

A narratividade aqui não é tratada como uma classe de textos (a narrativa), mas como uma narratividade mínima que todo texto possui. Veja que todo texto pressupõe estados iniciais e sua transformação, é assim que os textos se desenvolvem ${ }^{48}$.

Portanto, atualizando as oposições de valores em jogo no nível fundamental, o sujeito altera estados desenvolvendo um programa narrativo de aquisição de objeto. Os objetos podem ser modais ou objetos-valor. Os primeiros referem-se aos meios necessários para o sujeito praticar a transformação central do texto.

Em um conto de fadas, a espada mágica pode ser considerada o objeto-modal que permite ao cavaleiro derrotar o dragão e salvar a princesa. Seu acordo com o Rei para partir em busca do castelo em que está aprisionada a princesa é o que determina seu dever e sua condição de cavaleiro lhe confere o saber.

Veja que o exemplo da espada mágica dado acima pode variar, poderia ser o tapete voador, o pó de pirlim pim pim, o que está a informar que os objetos narrativos são mais abstratos que as figuras que o ocupam no nível discursivo, que são sua concretização efetiva.

${ }^{48}$ BARROS, Diana Luz Pessoa de. Teoria do Discurso. 03 ${ }^{\text {a }}$ edição. Humanitas. 2002. p. 27: “As operações da sintaxe fundamental convertem-se, na sintaxe narrativa e graças ao sujeito do fazer, em enunciados do fazer que regem enunciados de estado. Pode-se dizer que a conversão das operações lógicas em transformações narrativas é uma antropomorfização, em que a sintaxe narrativa, de caráter antropomórfico, substitui as operações lógicas da sintaxe fundamental por sujeitos do fazer e define sujeitos de estado pela junção com objetos-valor, formulando, portanto, sintaticamente, a relação básica do homem com o mundo." 
O mesmo ocorre com os actantes, cujas funções podem ser ocupadas por um mesmo ator do nível discursivo, embora diversas no nível narrativo, que é mais abstrato $^{49}$.

Objeto-valor é aquele perseguido pelo sujeito, com o qual ele quer entrar em conjunção ou permanecer em conjunção. É justamente essa relação entre o sujeito e o objeto-valor que vai dar fluência ao nível narrativo, construindo o sujeito em busca de seu objeto-valor por meio de programas de base e de uso para a aquisição de seu objeto.

O percurso gerativo do sentido toma a superfície do texto no nível discursivo. As questões tratadas em maior profundidade e abstração nas estruturas sêmio-narrativas (nível fundamental e nível narrativo), agora são recuperadas e a elas é dado um trato particular, conforme as opções do enunciador.

Da mesma forma que o nível fundamental e o nível narrativo, o nível discursivo possui uma estrutura sintáxica e uma estrutura semântica. Tratar da sintaxe discursiva de determinado texto implica tratar de questão crucial para a semiótica, qual seja, a instância da enunciação.

A enunciação deve ser compreendida como instância produtora do enunciado, devendo-se determinar a instância da enunciação por meio dos elementos presentes no enunciado que remetem a ela, que a pressupõem ${ }^{50}$.

Em qualquer texto em hipótese, é possível analisar como se dá a disposição das categorias de pessoa, tempo e espaço por meio de um sistema de embreagens e de debreagens.

Por meio da debreagem, projeta-se no enunciado quer a categoria de espaço, tempo ou pessoa do lugar da enunciação (debreagem enunciativa) ou do próprio enunciado (debreagem enunciva) ${ }^{51}$

\footnotetext{
${ }^{49}$ Essa questão é de grande importância para, em breve, compreender-se o traço característico da sintaxe do discurso jurídico.

${ }^{50}$ FIORIN, José Luiz. Elementos de Análise do Discurso. Cit. p - 39/40.
} 
Por meio da embreagem ocorre as oposições de pessoa, tempo e espaço entre a instância da enunciação e do enunciado ${ }^{52}$.

Por sua vez, quanto à sua estrutura semântica, o nível discursivo vai revestir as relações mais abstratas que compõem os textos com temas e figuras, de acordo com a seleção operada na instância da enunciação, que deliberadamente vai determinar quem são os "sujeitos" até então abstratos e quais ideais movem o sujeito a operar as transformações do texto.

Vejamos como esse modelo geral é operado quando aplicado a textos jurídicos por meio da análise das bases gerais dos principais estudos sobre o tema: "Sociedade Refletida", de Eric Landowski ${ }^{53}$ e "Semiótica e Ciências Sociais", de A. J. Greimas".

\section{Semiótica Jurídica - a palavra dos mestres}

Para caminhar em uma área do conhecimento, nada melhor do que observar e descrever o que os autores renomados dizem a seu respeito e, a partir daí, refletir e deduzir possíveis desdobramentos das idéias norteadoras.

Em princípio, parece que tanto Greimas quanto Landowski, mais do que encerrar os debates sobre a semiótica utilizada como recurso para a análise do discurso jurídico, nas obras acima referidas trataram de estabelecer suas linhas mestras, abrindo espaço para desenvolvimentos pontuais e monográficos às questões suscitadas ao longo de seus estudos preliminares.

\footnotetext{
${ }^{51}$ FIORIN, José Luiz. Elementos de Análise do Discurso. Cit. p - 41.

${ }^{52}$ FIORIN, José Luiz. Elementos de Análise do Discurso. Cit. p - 52.

${ }^{53}$ LANDOWSKI, Eric. Sociedade Refletida. EDUC/Pontes. 1992. Especialmente o Capítulo 3 da primeira parte da obra, "uma abordagem semiótica e narrativa do Direito".

${ }^{54}$ GREIMAS, A.J.. Semiótica e Ciências Sociais. Cultrix. 1976. Especialmente a Parte II, quando trata da "Análise semiótica de um discurso jurídico: a lei comercial sobre as sociedades e os grupos de sociedade."
} 
Como bem esclarece Landowski, não pretende a semiótica recriar a Teoria Geral do Direito, ou apenas renomear os elementos jurídicos com objetivos meramente teóricos, mas oferecer uma nova perspectiva de análise que, partindo de um método hipotético-dedutivo, possa abrir novos caminhos antes não considerados ${ }^{55}$.

A proposta de Landowski consiste em centralizar as atenções do semioticista, enquanto estudioso do fenômeno jurídico, na narratividade, ou seja, na construção de um percurso sintáxico abrangente o bastante para servir de base para tantas formações semânticas de superfície quantas forem possíveis de ser realizadas.

Ainda que haja indissociável relação entre a faceta semântica e sintáxica de determinada linguagem, o estabelecimento de uma coesa estrutura sintáxica do texto torna possível sua utilização independente do modelo semântico que ira revesti-lo, permitindo que, por meio de uma só estrutura, modalizem-se estados e fazeres das mais diversificadas maneiras.

Emergindo à superfície do texto, temos que as normas jurídicas elegem esta ou aquela conduta como sendo considerada "conforme o ordenamento jurídico", fundadas quer em razões sociológicas, históricas ou filosóficas.

\footnotetext{
${ }^{55}$ Nesse ponto, como bem explica LANDOWSKI, Eric. Sociedade Refletida. Cit. p 63-64: "Dirse-á que, em tudo isso, a semiótica não descobre nada: ela nada mais faz, em suma, senão denominar de maneira um pouco diferente as coisas já conhecidas e repertoriadas. Isto é verdade, mas nem por isso constitui, a nosso ver, uma objeção pertinente. Jogar com as denominações teria efetivamente pouco interesse se essa operação levasse a uma pura e simples substituição terminológica. Mas teremos compreendido que não é exatamente disso que se trata no caso presente e que a relação entre vocabulário jurídico existente e o vocabulário analítico proposto não é uma relação de equivalência e de preferência num mesmo plano, mas de uma superposição correspondente à hierarquização conceptual dos níveis de apreensão possíveis dos fenômenos a serem descritos, Não é um título de glória, para o semioticista, elaborar conceitos e, como veremos daqui a pouco, modelos de alcance por vezes mais abrangente que os especialistas das outras disciplinas constroem para as necessidades imediatas da sua prática. A cada qual seu ofício, ou antes, no caso, a cada qual seu nível de conceptualização!”
} 
No entanto, em todos os casos, a estrutura semio-narrativa mantém-se inalterada, revelando-se antes do seu revestimento discursivo, quando será recoberto por temas e figuras, que poderão tratar de toda sorte de direitos e obrigações passíveis de previsão pelas normas jurídicas.

Note-se que, diferente do capítulo anterior, o que a semiótica jurídica busca determinar é o processo de construção do sentido, seu percurso (conforme já salientado), valendo-se da elaboração de sistema de abordagem do texto para a melhor compreensão de como formalmente se comporta. É à análise da forma do texto legal, portanto, que se presta a semiótica jurídica.

Assim, sendo patente a existência de uma sintaxe narrativa própria às relações sociais que ocupam o direito, cabe explicitar seu funcionamento, o que é possível por meio dos aparatos teóricos dos domínios da semiótica ${ }^{56}$.

Talvez seja o caso de, empiricamente, observar como o aparato semiótico vai se amoldando ao discurso jurídico e registrar as mudanças que opera para dar conta de resolver questões peculiares desse ramo do conhecimento.

Fica estabelecida, assim, a proposta do que se pode considerar efetivamente como uma semiótica jurídica, em oposição a uma possível semiótica do direito, como esclarece Landowski ${ }^{57}$ :

\footnotetext{
${ }^{56}$ LANDOWSKI, Eric. Sociedade Refletida. Cit. p 61: "Como bem esclarece o autor, "a rigor, podemos até imaginar, numa perspectiva antropológica, uma sociedade que não isolasse em absoluto o "fenômeno jurídico" enquanto tal, que, por exemplo, não tornasse autônomas, sob a forma de instituições particulares e especializadas, as funções "legislantes" ou "jurisdicionais", que não comportasse "profissões jurídicas" reconhecidas, que não tivesse "diário oficial", por falta de textos especificamente "jurídicos" a serem levados ao conhecimento do público - em suma, uma sociedade que não fizesse uso do "direito" enquanto categoria semântica autônoma. Mas se tal sociedade existisse, ela não poderia deixar de fazer uso de um mínimo de regras, ao menos implícitas, destinadas a organizar as relações entre seus membros - de troca, parentesco, etc. Mesmo que o direito estivesse ausente do dicionário conceitual de tal cultura, certa presença jurídica nela não deixaria de ser necessariamente detectável na forma de algum sistema de regras sintáxicas, isto é, gramaticais, a regerem relações sociais.”
} 
"Na medida em que se pode admitir que os dispositivos característicos do nível "superficial" (em que a norma já se acha investida na rede semântica de determinado sistema de direito positivo) apenas aplicam, em sua ordem própria, as regras de uma sintaxe mais fundamental (pertencente ao nível profundo que acabamos de postular), admitir-se-á também que a análise semiótica dos dispositivos ditos superficiais passa pela construção prévia de modelos mais gerais que assumem diretamente como objeto essa sintaxe fundamental, independentemente de seus modos de investimento particulares em determinada manifestação de superfície. Não fosse a presunção das diferenças terminológicas demasiado "sutis", poder-se-ia marcar explicitamente esta hierarquia de níveis aplicando de preferência a expressão "semiótica do direito" (ou dos sistemas de direito positivo) aos estudos que têm em vista o primeiro nível, e reservando a de "semiótica jurídica" (lato sensu) para as pesquisas pertencentes ao segundo nível.”

Pois bem, uma vez determinada qual a denominação da matéria aqui tratada semiótica jurídica -, cabe determinar qual o objeto a ser estudado. Elegemos as codificações civis brasileiras, ou seja, o conjunto de normas de direito positivo que regem as relações entre particulares em território nacional, tendo como finalidade a construção de um princípio de classificação semiótica desse complexo de normas, que será iniciado com a apreensão da sintaxe narrativa que dá fundamento àquelas.

\subsection{Sintaxe narrativa do direito positivo}

Conforme explicado no capítulo anterior, o traço fundamental que une as mais variadas e quase infinitas definições do que vem a ser norma jurídica é que se tratam de regras deontológicas, que não se preocupam com considerações subjetivas de seus destinatários, mas no dever destes em observá-las enquanto normas reguladoras de condutas passíveis de serem impostas sob pena de sanção, dotadas de característica específica de coercitividade, ou seja, de serem impostas e regrarem efeitos independentemente da vontade de seu destinatário.

${ }^{57}$ LANDOWSKI, Eric. Sociedade Refletida. Cit. p 62 
É assim que à testemunha é obrigatório o comparecimento em juízo para depor sobre os fatos sobre os quais tenha conhecimento, na hora e data designadas, sob pena de condução "sob vara", na hipótese de se recusar a fazê-lo deliberadamente e responder, conforme o caso, pelo crime de desobediência, por desrespeitar a uma ordem legal e judicial.

E, em qualquer hipótese, quando desejamos que a nossas condutas seja conferida a qualidade de "conforme o ordenamento", devemos realizá-la conforme o prescrito em norma jurídica.

Tome-se a celebração do casamento como exemplo. Uma celebração de casamento encenada em uma peça de teatro não gera vínculo matrimonial entre as partes, uma vez que não estão presentes os pressupostos jurídicos necessários para que aquele ato se torne juridicamente relevante.

Fosse assim, de toda festa junina, restariam casamentos indesejados, cujos participantes têm como móvel pura e simplesmente a reiteração de uma tradição local.

Por outro lado, o casamento celebrado em Cartório de Registro das Pessoas Naturais, observadas as formalidades legais, gera efeitos jurídicos que obrigam as partes, independente da vontade das mesmas no que diz respeito às conseqüências de seus atos.

Vale dizer, os efeitos jurídicos decorrem da previsão legal, são da ordem do dever-ser, uma vez realizados de acordo com o prescrito em lei. Por outro lado, ainda que desejado, não opera efeitos jurídicos, caso não sejam observados os requisitos legais para sua celebração.

Do que foi dito acima, nota-se uma interessante distinção entre os atos passíveis de realização pelos sujeitos no "mundo natural", que podem ser infinitos, e aqueles que se revestem de relevância jurídica. 
Antes de explorarmos as relações entre o que pertence ao universo jurídico e sua relação com o mundo natural, retomemos as lições de Landowski que, tratando da sintaxe narrativa, dá as primeiras pistas para a elucidação da questão, uma vez que explica pontualmente como se estabelece a gramática narrativa que dá sustento às normas jurídicas em geral.

Tendo esclarecido que a narratividade em semiótica consiste na imbricação de um modelo actancial e uma sintaxe modal, tratando de distingui-lo da abordagem clássica desenvolvida pela lógica e pela metalógica, conclui o autor que, encarado sob aquela perspectiva,

"o direito não poderia ser - ao contrário do que frequentemente se diz, com base nas aparências - editar, em forma de Decálogo ou de catálogo, séries de prescrições e de proibições, mas sim, como também se diz, aliás, de maneira menos trivial, regulamentar as relações. $O$ direito não regulamenta diretamente o fazer dos atores sociais, ou, pelo menos, não esta aí seu princípio essencial; em compensação ele distribui valores modais, cita-os, desloca-os ou, simplesmente, se necessário, reconhece valores modais preexistentes à sua intervenção; assim fazendo, confere um estatuto jurídico aos regimes de relações intersubjetivas que as configurações modais assim criadas ou reconhecidas comandam." 58

O direito positivo preocupa-se com as relações estabelecidas entre os indivíduos e isto o impõe como norma reguladora da vida em sociedade. Daí porque foge ao interesse do direito atos que padeçam de alteridade, uma vez que é na relação com o outro que o ato se torna juridicamente relevante.

É por isso que a maior parte das nações entendem por bem não punir aqueles que tentam o suicídio. Pode-se até dar uma explicação de cunho humanista ou de política criminal, tal como não ser razoável punir aquele que já se dispôs a abrir mão do seu bem maior, ou seja, a vida.

${ }^{58}$ LANDOWSKI, Eric. Sociedade Refletida. Cit. p 65 
De que adiantaria a punição para aquele que pretende se auto-punir com a pena capital?

No entanto, o fato é que, por não esbarrar na órbita de direitos e deveres jurídicos dos demais indivíduos, tal conduta, em si mesmo considerada, torna-se juridicamente irrelevante.

É claro que para os pais do adolescente que tenta cometer ou comete suicídio, tal fato por si só é uma pena das mais severas, mas que não é aplicada pela sistemática jurídica, salvo se tenham de alguma maneira, auxiliado material ou moralmente para o suicídio, conforme se verá mais adiante.

Veja que, em abstrato, seria perfeitamente possível a punição do suicida frustrado, no entanto, é característico do direito positivo deixar de lado relações reflexivas, em que há uma sincretização de papéis em um mesmo sujeito.

O exemplo de Landowski é o ato unilateral e sua desconsideração para efeitos civis, ao contrário das relações que pressupõem sinalagma, ou seja, contraprestações mútuas entre os indivíduos.

Agora, o "fato" suicídio pode desencadear relações no "mundo natural", que se revestem de relevância jurídica, de "juridicidade", na medida em que afetam a esfera de direitos de outros indivíduos.

Será de relevância jurídica a transmissão dos bens do suicida a seus herdeiros; será, da mesma forma, relevante determinar-se quais as circunstâncias do suicídio, se outrem participou induzindo, instigando ou auxiliando o suicida, hipótese na qual está sujeito às sanções previstas no art. 122 do Código Penal.

A empresa de seguros certamente investigará o caso para determinar se o suicídio (ou tentativa) foi cometido com o objetivo de fraudar seguro de vida, crime previsto no art. 171, inciso VI do Código Penal e com sanções pecuniárias prevista na legislação civil; etc. 
Temos que, em todas as situações acima, o que levou o suicídio a ter relevância jurídica, foi desencadear transformações de estado de outros sujeitos, enquanto o "fato" suicídio em si mesmo considerado não ultrapassa a esfera individual, portanto, permanece juridicamente irrelevante.

Vale dizer, no universo jurídico, não há que se falar em relações em que um mesmo indivíduo é o sujeito ativo e passivo da ação.

Aos herdeiros caberá tomar as medidas necessárias para apropriarem-se do patrimônio do de cujus, que a eles o doa em razão de seu falecimento, nos termos das normas que tratam das sucessões ${ }^{59}$.

Ao que prestou auxílio moral ou material ao suicídio cabe a sanção criminal, ou melhor, cabe ao Estado provar a ação anti-jurídica do mesmo e sancioná-lo penalmente (negativamente, no modelo canônico da semiótica), nos moldes da legislação penal e processual penal.

À seguradora caberá doar parte de seu patrimônio em favor dos herdeiros do falecido, caso não se entenda espoliada pela possível ação fraudulenta daquele, que pode levá-la a se recusar a pagar o prêmio do seguro (objeto-valor), frustrando o

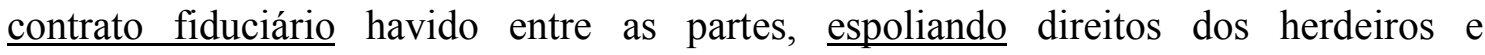
provocando-os, o que pode levá-los a um percurso de aquisição de seu objeto-valor.

Percebe-se, pela série de termos grifados, como o modelo de sintaxe narrativa dá conta de explicar a construção do discurso jurídico por meio de transformações de estados e operações elementares de conjunção e disjunção entre sujeitos e valores (modais ou objeto-valor).

Por esta breve análise também encerra-se uma questão elementar no ramo do direito, qual seja, a tendência de não-sincretizar os papéis actanciais em um mesmo ator de superfície, sendo a regulamentação das relações intersubjetivas seu objeto de apreciação, dos quais depreende suas normas.

\footnotetext{
${ }^{59}$ O Código Civil ocupa-se, em seu Livro V, com o Direito das Sucessões.
} 
Mas não explica satisfatoriamente a pergunta suscitada linhas acima: como fatos do mundo natural passam a ter revestimento de juridicidade?

\subsection{Prática Jurídica - produção e verificação jurídica}

Tomem-se as relações havidas entre condôminos for força de possuírem imóveis em condomínios edilícios. A sua existência efetiva se deveu por razões de ordem econômicas e sociais que obedeceram às suas próprias leis: por um lado, pode-se imaginar que é economicamente mais vantajoso construir em determinado terreno unidades imobiliárias verticalmente, o que possibilita a construção de centenas de unidades em um único local que, com um aproveitamento apenas horizontal do imóvel, teria suas dimensões bem mais limitadas.

Da mesma maneira, parcelando o imóvel em diversas unidades autônomas sua venda se torna mais viável, uma vez que diz respeito a apenas uma parcela do todo que consiste no terreno construído.

Pelo enfoque social, temos que as grandes metrópoles concentram as atividades comerciais e industriais de determinado povo, levando ao crescimento demográfico. Como muitas pessoas tendem a ocupar a mesma região, há que se dar solução adequada para o problema de moradia. Daí o surgimento de condomínios edilícios, que permitem que, muitas vezes, milhares de pessoas dividam o mesmo espaço comum e tenham neste espaço suas unidades autônomas de moradia.

Embora mais recente e, talvez, menos relevante, o que parece colaborar para a desenfreada ocupação do solo por condomínios edilícios é a criminalidade sempre crescente e o efeito de proteção que se cria ao residir próximo a mais pessoas supostamente de mesma condição financeira que investem na segurança mútua dentro dos domínios de sua propriedade comum.

Assim, podemos dizer que o fato dos indivíduos se reunirem em condomínios edilícios é fato do mundo natural, pertencente ao que poderíamos denominar, escorados em Greimas, "discurso referencial", aquele que trata de definir os elementos que 
poderão ser apropriados pelo discurso que lhe utiliza como referência, no nosso caso, o “discurso legislativo".

Neste momento, será de maior proveito passarmos o foco de nossa pesquisa para a obra de Greimas, "Semiótica e Ciências sociais", eis que ali resta mais profundamente explorada a relação entre o já denominado "nível referencial" e o "nível legislativo". Após, voltamos a Landowski para considerações finais quanto à sintaxe narrativa do discurso jurídico.

De qualquer modo, foi Landowski quem realizou os estudos preliminares sobre semiótica jurídica que Greimas organizou e fez incluir em sua obra supracitada não havendo, portanto, qualquer discrepância conceitual que impeça a análise concomitante das duas obras para revelar o que se mostra fundamental para o desdobramento deste trabalho ${ }^{60}$.

Enfim, Greimas propõe que o discurso jurídico é fundamentado nas relações estabelecidas entre dois planos distintos, o primeiro pertencente aos domínios da língua natural e o segundo expresso em linguagem jurídica, que possui regras sintáxicas e dicionário próprio.

O discurso jurídico, dentre tantos outros, como o discurso científico em geral, enuncia-se por meio de uma linguagem própria que é criada assumindo termos da língua natural e conferindo a eles especificidade semântica, ou seja, transformando termos manifestamente polissêmico em monossêmicos, como é o caso da linguagem jurídica ${ }^{61}$.

Com efeito, o discurso jurídico, apropriando-se da língua natural, dá a seus termos significações específicas, por meio de um dicionário próprio que, não por isso,

${ }^{60}$ GREIMAS, A.J. Semiótica e Ciências Sociais. Cit p. 71: "O estabelecimento do texto definitivo foi então confiado a um dos pesquisadores, Eric Lanowski, que, retomando mais uma vez a análise desde o começo, elaborou um documento de 181 páginas, das quais o texto que segue constitui uma espécie de resumo, completado e remanejado pelo responsável pela pesquisa, que assume tanto as conclusões coletivas como os pontos de vista pessoais que foi levado a introduzir.

${ }^{61}$ GREIMAS, A.J. Semiótica e Ciências Sociais. Cit p.73. 
deixa de manter relações com a língua natural da qual se utiliza (no nosso caso, o português).

Ao lado desse dicionário jurídico, há a gramática jurídica, que estabelece a maneira como os elementos paradigmáticos estabelecerão relações sintagmáticas e, dessa forma, desencadearão o discurso jurídico.

O discurso jurídico se baseia em uma dupla isotopia: a primeira que se refere ao discurso legislativo e a segunda que se refere ao discurso referencial. $O$ discurso legislativo é composto de enunciados performativos e normativos que conferem existência jurídica a determinados fatos e pessoas que advêm do discurso referencial, entendido como o próprio mundo social anterior à fala que o articula ${ }^{62}$.

Relação curiosa esta, que remete diretamente às peculiaridades do discurso jurídico que, não obstante ser criado a partir de determinada língua natural, dela se destaca ao criar uma sintaxe e semântica peculiar, apropriando-se dos termos destacados daquele discurso, que lhe é referência.

É assim que podemos dizer que o nível legislativo vai atribuir sentido jurídico para determinados fatos do nível referencial, que se entendem como um "a priori" lógico que a fala legislativa apenas descreve e organiza.

Como já se disse, o discurso jurídico possui uma gramática própria, que só recepciona aquelas construções que se mantenham intactas diante de seus critérios próprios de verificação, uma vez alçadas do nível referencial. Da mesma forma, como também já se viu, possui uma semanticidade própria, ou seja, um dicionário jurídico autônomo.

Como se dá, então, a passagem dos fatos do nível referencial ao nível legislativo? Por meio do que Greimas denomina "prática jurídica".

${ }^{62}$ GREIMAS, A.J. Semiótica e Ciências Sociais. Cit p.73-74. 
Antes de compreender melhor esta intricada relação, expomos o seguinte quadrado semiótico formado a partir da oposição /gramaticalidade/vs/semanticidade/, extraído do livro ora em debate, que corresponde ao nível fundamental da relação entre o discurso referencial e o discurso jurídico ${ }^{63}$ :

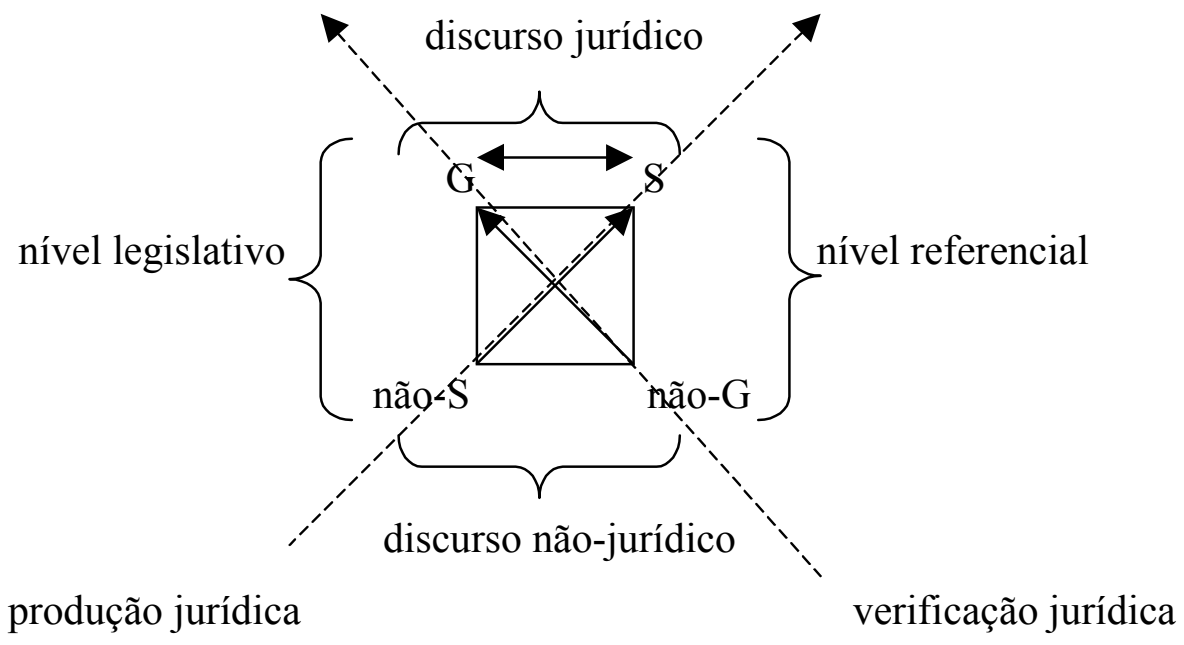

$\mathrm{G}=$ gramaticalidade jurídica

não-G = agramaticalidade jurídica

$\mathrm{S}=$ semanticidade jurídica

não-S = assemanticidade jurídica

$\mathrm{G}+\mathrm{S}=$ discurso jurídico (constituído por uma gramática e uma semântica)

não-G + não-S = discurso não-jurídico (juridicamente agramatical e assemântico)

G+ não-S = nível legislativo (gramática jurídica, sem conteúdo)

não-G $+\mathrm{S}$ = nível referencial (universo jurídico virtual, sem gramática jurídica)

não-S $\rightarrow \mathrm{S}=$ produção jurídica $\left\{\begin{array}{l}\text { transformação do conteúdo virtual em } \\ \text { conteúdo jurídico, implicando o uso da } \\ \text { forma gramatical }\end{array}\right.$

$\frac{\text { não-G } \rightarrow \mathrm{G}=\text { verificação jurídica }}{{ }^{63} \text { GREIMAS, A.J. Semiótica e Ciênciфs Sociais. Cit p.81-82. }}$ 
plicando a semanticidade jurídica de seu

conteúdo

Pois bem. Com base no quadrado colacionado, vejamos como definir o que se entende por produção jurídica e verificação jurídica.

Produção jurídica é o mecanismo que se vale o legislador para a elaboração das leis, transformando elementos juridicamente assemânticos do discurso referencial em juridicamente semânticos, ao integrá-los na gramática jurídica, ou seja, no campo das prescrições e proibições legais.

Para melhor exemplificar o que está sendo dito, convém retomar a questão dos condomínios edilícios, por hora apenas encarada como fato do mundo natural para verificarmos como o legislador dá a esse fenômeno revestimento jurídico, conferindolhe gramaticalidade e semanticidade própria.

Podemos bem notar como a norma jurídica trabalha a dupla isotopia do nível referencial e do nível legislativo. Se, por um lado, não há dúvida de que o direito surge como regramento de relações intersubjetivas preexistentes no nível referencial, por outro faz delas o seu discurso, conferindo-lhe semanticidade jurídica.

Vale dizer, a partir do momento em que as relações havidas entre os sujeitos passam a ser consideradas juridicamente relevantes e cria-se todo um regramento sobre o tema, os atos que assim são regulados deixam de depender da vontade dos sujeitos e se tornam um dever-ser ou dever-fazer para os mesmos, de acordo com prescrições e proibições que se apresentam por meio de normas jurídicas.

Ocorreu, então, produção jurídica, ou seja, um termo provido de gramaticalidade jurídica (o corpo abstrato da norma, as transformações de estado e os actantes) é revestido por um termo do nível referencial, juridicamente assemântico, portanto, e que passa a ter semanticidade jurídica, tornando-se parâmetro de conduta social, pela fala do legislador. 
Para melhor esclarecer a sintaxe narrativa que serve de base para as normas jurídicas, destaquemos alguns artigos de lei que tratam dos condomínio edilícios (Anexo I) para conferirmos como operam de maneira regular.

Em primeiro lugar, é de se notar a natureza intersubjetiva de todos os artigos de lei expostos, conforme explorado linhas acima, o que confirma que a norma positiva pressupõe alteridade, que não se presta analisar ações que dizem respeito apenas ao indivíduo.

Veja que o legislador, até mesmo ao tratar de determinar o que é propriedade de uso exclusivo e propriedade de uso comum, deixa claro que:

Art. 1331 Código Civil/02: "Pode haver, em edificações, partes que são propriedade exclusiva, e partes que são propriedade comum dos condôminos (art. 1331).§ $1^{\circ}$ As partes suscetíveis de utilização independente, tais como apartamentos, escritórios, salas, lojas, sobrelojas ou abrigos para veículos, com as respectivas frações ideais no solo e nas outras partes comuns, sujeitam-se a propriedade exclusiva, podendo ser alienadas e gravadas livremente por seus proprietários." (grifo nosso)

Ao conjunto das normas que cuidam dos condomínios edilícios não interessa regular o que diz respeito exclusivamente ao "condômino", considerado na relação direta com sua "propriedade exclusiva", que poderá ser objeto do aparato legislativo que trata dos direitos reais.

A este capítulo da codificação civil em vigor, interessa o sujeito apenas enquanto pertencente a uma relação condominial do que denomina "propriedade comum".

O que ajuda a esclarecer que o modelo sintáxico narrativo do direito positivo procura dar conta de apreender relações suficientemente gerais e abstratas para abarcar uma série infindáveis de condutas humanas passíveis de serem enquadradas em sua grade de prescrições e proibições.

Temos, de um lado a figura do legislador, Destinador na relação estabelecida com os sujeitos de estado (condôminos) - o qual, conforme teremos oportunidade de ver ao final deste capítulo, submete-se ao que Landowski denomina "metadestinador 
epistemológico" -, aos quais vai impor um dever-fazer/dever-ser para que suas condutas sejam consideradas conforme o ordenamento jurídico.

É assim que determina que:

Art. 1332 CC/02: "Institui-se o condomínio edilício por ato entre vivos ou testamento, registrado no Cartório de Registro de Imóveis, devendo constar daquele ato, além do disposto em lei especial: I - a discriminação e individualização das unidades de propriedade exclusiva, estremadas uma das outras e das partes comuns; II - a determinação da fração ideal atribuída a cada unidade, relativamente ao terreno e partes comuns; III - o fim a que as unidades se destinam.”

Veja que o Destinador-legislante está a determinar, por intimidação o percurso a ser seguido pelos condôminos para que possam entrar em conjunção com seu objetovalor que é a propriedade compartilhada, o condomínio.

A norma impõe um dever-fazer para o sujeito poder-fazer o que deseja. É a transcrição da máxima "Se $x$ deve (prescrição) fazer A, então $x$ pode (permissão) fazer A.".

Art. $1.333 \mathrm{CC} / 02$. "A convenção que constitui o condomínio edilício deve ser subscrita pelos titulares de, no mínimo, dois terços das frações ideais e torna-se, desde logo, obrigatória para os titulares de direito sobre as unidades, ou para quantos sobre elas tenham posse ou detenção.

Parágrafo único. Para ser oponível contra terceiros, a convenção do condomínio deverá ser registrada no Cartório de Registro de Imóveis.”

Da mesma forma, neste caso, para "a convenção que constitui o condomínio edilício" poder-ser "oponível a terceiros", deverá-ser "registrada no Cartório de Registro de imóveis.".

O próximo artigo de lei (1334) prescreve que "além das cláusulas referidas no art. 1332 e das que os interessados houverem por bem estipular, a convenção determinará:” e seguem incisos tratando do tema. Veja que o trecho em destaque faz 
realçar a nítida existência de condutas "não prescritas" em lei, ao lado de condutas "não proibidas", melhor analisadas a partir do seguinte quadrado semiótico ${ }^{64}$ :

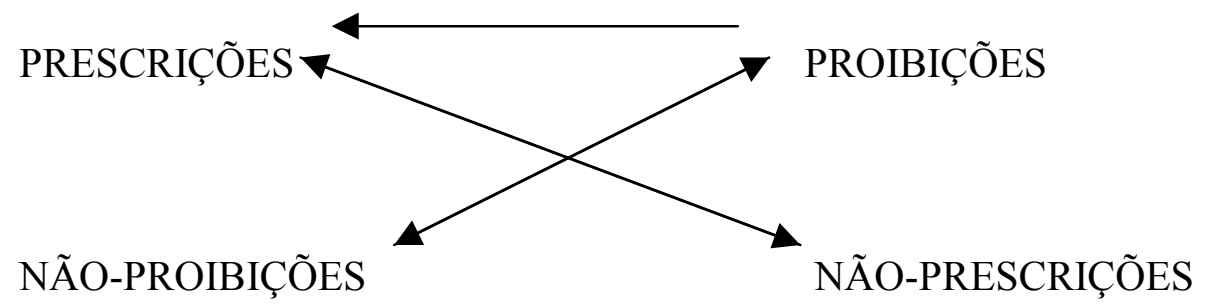

Ora, o que os interessados haverão por bem estipular em suas convenções foge do regramento jurídico, abrindo aí a possibilidade dos indivíduos determinarem o que melhor lhes aprouver no que concerne às peculiaridades de cada condomínio edilício.

No entanto, uma vez estipulado e aprovado, na forma da lei, passa a valer com a mesma eficácia, entre os condôminos e eventuais ocupantes e visitantes, como se lei fosse.

Uma vez criados os papéis actanciais e a sintaxe narrativa pelo legislador, ao sujeito-manipulado que pretender ser sancionado positivamente pelo ordenamento jurídico cabe o dever de observar a prescrição legal e agir daquela maneira, sob pena de ser sancionado negativamente por seu ato.

Se não registrar a convenção condominial, conforme determinado em lei, não fará jus aos benefícios legais no que se refere a ação de defesa de direitos reais e obrigacionais; se não pagar a cota condominial em dia estará sujeito a pagá-la com os acréscimos determinados em lei, etc.

Para tratar dos mecanismos que permitem a verificação da regularidade dos atos dos componentes do condomínio, como unidades partitivas desse actante coletivo, há o

\footnotetext{
${ }^{64}$ GREIMAS, A.J.. Semiótica e ciências sociais. Cit. pág. 79.
} 
eficiente modelo proposto por Greimas na parte final da obra que seguimos de perto (“Semiótica e Ciências Sociais"65).

Em suma, Greimas propõe que o actante coletivo sintagmático é aquele composto por sujeitos que complementam entre si suas atribuições, como no caso de uma linha de produção de montadora de carros, uma metalúrgica, uma indústria de alimentos, que reúnem engenheiros, operários, técnicos, pessoal burocrático, em que cada um tem seu espaço de atuação bem definido.

Já os actantes paradigmáticos não comportam a distinção dos sujeitos que a compõe à maneira de números ordinais, uma vez que se confundem uns com os outros na criação de uma totalidade que transcende a individualidade das unidades integrais.

É justamente o que ocorre com os condomínios edilícios, a quem é conferido o status de pessoa jurídica, de acordo com ordenamento, uma ficção criada pelo legislador para reconhecer juridicamente a existência de um actante coletivo paradigmático que surge da comunhão de vontades.

Assim, os proprietários das unidades autônomas, enquanto senhores de seus bens, não sofrem qualquer interferência do regramento da legislação condominial, que só se interessa por esse sujeito (unidade integral), como unidade partitiva que dá vida, junto a outras unidades partitivas, à totalidade partitiva, que é o condomínio.

Emprestamos para explicitar graficamente essa relação o seguinte esquema de Greimas $^{66}$ :

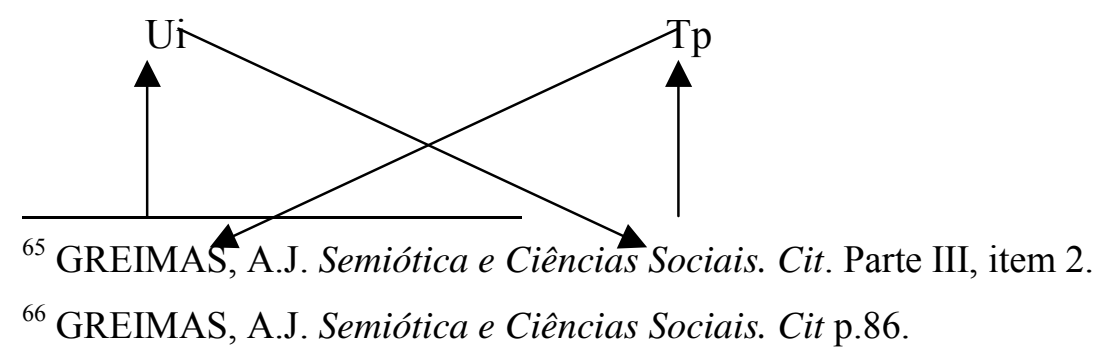


Percebe-se, assim, que o condômino, enquanto proprietário de um apartamento é unidade integral (Ui), transformando-se em unidade partitiva (Up) em razão de possuir parte do imóvel comum, onde se estabelece, em união às demais unidades partitivas a totalidade partitiva (TP) conhecida como condomínio, que passa a totalidade integral (Ti).

É de se destacar também que é o vínculo patrimonial que determina o liame entre os participantes do condomínio, ou seja, o fato de serem proprietários de uma porção da propriedade comum e a relação destes com seu bem comum.

Certamente onde há patrimônio comum, abre-se margem para uma série de discussões, discordâncias e disputas para se determinar qual o melhor caminho para a subsistência do actante coletivo.

Cumpre ressaltar que, a apropriação da abordagem empreendida por Greimas para a análise que aqui se pratica necessita de evidentes adaptações em virtude da diferença dos segmentos tratados, o que está longe de significar que os modelos semióticos não são efícientes o bastante para se manterem estáveis frente a qualquer objeto.

Pelo contrário, em razão de seu método (como já se disse, hipotético-dedutivo), permite-se a perfeita harmonia entre seus princípios norteadores e as necessidades do objeto em concreto. Tanto é assim que, mais adiante, o mesmo modo de abordagem do actante coletivo será utilizado para tratar das entidades familiares.

Enfim, a adaptação que se faz necessária diz respeito aos fins das sociedades comerciais (estudada por Greimas) e dos condomínios edilícios (que nos ocupa aqui), uma vez que aqueles visam ao lucro por meio de suas práticas, ao passo que os condomínios prestam apenas para administrar os interesses comuns de seus participantes. 
É assim que a cada parte ideal do imóvel comum vincula-se uma obrigação de arcar com determinada fração das despesas do condomínio, denominadas cotas condominiais.

A totalidade das contribuições condominiais constituirá o patrimônio que permitirá o condomínio, como totalidade partitiva, fazer frente às obrigações do actante coletivo frente a terceiros (contas de água de todo o imóvel, luz, telefone, produtos de limpeza, peça de reposição, serviços de reparos e manutenção).

Para que essa estrutura se movimente, criam-se papéis actanciais para o sujeito que vai administrar esse patrimônio e para o sujeito investido de competência para controlar a regularidade dos atos praticados por aquele, no interesse de todos.

Em outras palavras, constitui-se um contrato entre os participantes unidos pela vontade comum de viverem confortavelmente, esse contrato para condomínios é a Convenção Condominial.

Por meio da convenção condominial fica determinada a forma de existência e manutenção desse actante coletivo, só podendo ser alteradas por maioria absoluta, na maioria do casos e como se depreende da análise perfunctória da lei em anexo (ANEXO I).

Um síndico é eleito para cumprir o papel-actancial de administrador dos interesses do condomínio, por maioria de votos computados proporcionalmente à quantidade de parte ideal que possui do imóvel cada membro que compõe a Assembléia Geral. Além do síndico, pode haver a previsão de eleição de um conselho fiscal, destinado a examinar as contas do condomínio.

Seguindo a máxima que vimos explorando, qual seja, da tendência do direito de discretizar os papéis-actanciais, é conferida existência jurídica a uma Assembléia, que reúne todos os participantes do condomínio, que decidem por maioria (por vezes simples, por vezes qualificada) a eleição de um actante-síndico que deverá administrar o condomínio querendo-fazer o que é o melhor para todos e os atos desse actante-síndico serão verificados pela Assembléia Geral Ordinária, que aprovará ou impugnará as cotas 
do período e ainda, em alguns casos, o Conselho Fiscal, composto de 03 (três) membros que analisam previamente as contas condominiais.

Percebe-se, portanto, que a lei confere aos particulares mecanismos de autogestão, que permitem o controle de regularidade na administração da coisa comum, possibilitando, inclusive, a cobrança de multa para os infratores da convenção condominial, sendo certo que quanto maior o condomínio edilício, maior a complexidade de sua administração.

Além disso, não deixa de ser curioso notar como o "sistema de governo" determinado pelo legislador para os condomínios é o mesmo adotado pelo Brasil, o presidencialista.

Talvez porque de fato existam condomínios que são verdadeiras cidades, notadamente os comerciais e, dado à grande quantidade de interlocutores, não há como se decidir por consenso, mas só pela voz da maioria referendada pelo poder soberano, que é conferido pelo povo que para seu representante naquele síndico votou.

Se é bem verdade que quanto menor as proporções do condomínio edilício, menor a necessidade de tamanho controle e verificação de contas (o condomínio edilício pode reunir, conforme o caso não mais do que duas pessoas), da mesma forma que ocorre nas sociedades comerciais (se são de atuação modesta e compostas por poucos sócios), por outro lado mais estreita é a vinculação à fidúcia estabelecida entre as partes, independente da eficiência administrativa, o que pode ser sede maior de debates quanto à atuação do síndico.

Além de proporcionar um mecanismo de controle interno para o condomínio, claro que estes próprios controles podem ser debatidos em outra instância, aquele composta por sujeitos investidos pelo Estado que lhes confere o poder de dizer o direito no caso concreto, o que nos traz de volta à prática jurídica, mais especialmente a verificação jurídica.

Uma vez determinadas a priori as relações jurídicas a que o ordenamento jurídico vai conferir existência, pelo fenômeno da verificação jurídica, o destinador- 
judicador aprecia a adequação de determinada ação com o prescrito em lei, verificando a sua adequação gramatical com o discurso jurídico.

Vale dizer, ao tratar das ocorrências do nível referencial, o destinador-judicador promove a confronto do fato do mundo natural (NATUREZA) com a prescrição legal (CULTURA), para assim determinar se há semanticidade jurídica de seu conteúdo.

Voltemos agora às lições Landowski para explicar melhor essa questão da constante verificação dos conteúdos gramaticais e semânticos do discurso jurídico, ainda norteados pelos elementos mais significativos do discurso jurídico que apreendemos, tais como intersubjetividade, heteronomia e discretização de papéis actanciais.

Pelo que já foi dito, o que salta aos olhos é o fato do discurso jurídico operar uma distinção entre os sujeitos a quem conferem o dever-poder de elaborar leis e àqueles a quem conferem o dever-poder de examinar a adequação do fato referencial ao previsto em lei.

E não só, como também o poder de determinar a adequação da própria lei como ferramenta de verificação, uma vez que pode padecer de inconstitucionalidade, que será declara, ainda que apenas naquele caso.

É este o papel da prática jurisprudencial, que a todo o momento verifica os critérios de validade e eficácia da linguagem jurídica instituída, para concluir se as condutas praticadas pelos indivíduos a ela estão adequadas.

E mais, se a própria norma jurídica permanece conforme os anseios de justiça, na figura agora do destinador-julgador, que se materializa na figura do Poder Judiciário e sua estrutura.

Assim, a norma jurídica que é criada, em regra, pelo Poder Legislativo (em que pesem o mar de medidas-provisórias, emanadas pelo executivo, que no mais devem ser ratificadas pelo legislativo para permanecerem válidas e sujeitas a análise de constitucionalidade pelo judiciário), fruto da produção jurídica, é submetida à verificação jurídica, por meio da atividade dos sujeitos participantes do Poder Judiciário. 
Mais adiante, trataremos detidamente de como a jurisprudência é responsável pelas alterações de corpos legislativos das mais diversas naturezas, funcionando como fonte do direito, eis que expressam as transformações sociais no seu contato direto com prescrições normativas por vezes arcaicas e que necessitam ser alteradas (ou no mínimo de interpretação condizente).

Do que foi dito podemos notar que tanto o Destinador-manipulador da produção jurídica (legislador), que previne as relações a priori, quanto o Destinador-julgador (juiz), que pratica ato cognitivo a posteriori pela verificação jurídica, estão, da mesma forma sujeitos a um outro destinador (ou destinadores) que a suas ações observam e em cuja relação, transformam-se em destinatários, sujeitos de estado.

Não é apenas nas relações de coordenação entre os sujeitos de direito que a discretização determina os passos da sintaxe jurídica. O mesmo se observa nas relações "verticais", ou seja, de hierarquia entre destinadores legislante e judicante que também são diversos necessariamente.

Segundo Landowski, ambos os destinadores que manipulam e determinam as relações de coordenação entre os sujeitos que se submetem ao discurso jurídico, recebem a denominação de "destinadores axiológicos" os quais, por sua vez, subordinam-se ao que denomina "destinador epistemológico", que seria, nas palavras do autor, a teoria do direito, ou ainda as regras virtuais de direito ${ }^{67}$.

Essas relações podem ser expressas no seguinte esquema ${ }^{68}$ :

Nível epistemológico

("normas" metajurídicas)

Metadestinador epistemológico

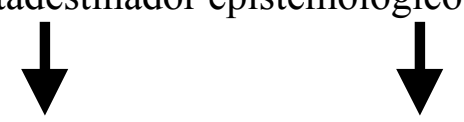

Nível axiológico

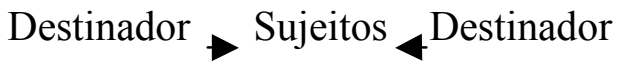

("regras" de direito)

legislante de direito judicador

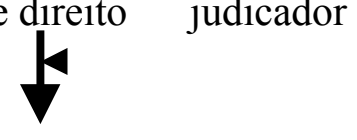

\footnotetext{
${ }^{67}$ LANDOWSKI, Eric. Sociedade Refletida. Cit. p 74.

${ }^{68}$ LANDOWSKI, Eric. Sociedade Refletida. Cit. p. 74.
} 
Nível referencial

("leis" de comportamento)
Atores sociais quaisquer

Os destinadores axiológicos, que discretizam-se ocupando cada um seu papel, conferem à sintaxe narrativa do discurso jurídico uma peculiaridade em relação aos demais tipos de norma que, em regra, concentram em apenas um actante o poder de determinar o modo de ação e a decisão sobre o ato realizado pelo sujeito de direito, bem como de ditar o comportamento dos indivíduos e não propriamente suas relações intersubjetivas ${ }^{69}$.

Esse sistema acima delineado, em que sujeitos do fazer tornam-se sujeitos de estado, submetendo sua ação anterior a um destinador hierarquicamente superior, é o que define a singularidade da gramática jurídica, mais preocupada com a forma, ou seja, com a regulamentação das relações, do que com sua substância, o que não se alcança por esse modelo sintáxico, tornando a norma jurídica livre das conceituações daqueles que preenchem os papéis actanciais que se presta a definir.

Agora se faz necessário detalhar como esse sistema ao tornar-se processo se comporta visando a manter a ordem sem deixar de incorporar as modificações que a vida em sociedade determina.

${ }^{69}$ A esse respeito, é esclarecedora e digna de nota a conclusão de LANDOWSKI, Eric. Sociedade Refletida, Ip. 77: "Se essa previsão se verificasse, ter-se-ia aí uma confirmação empírica da idéia de que o tópico do direito é, de fato, antes de mais nada, 'regulamentar relações'. Observação não trivial, parece-nos, na medida em que permite acrescentar aos critérios de distinção clássicos entre o direito e os outros sistemas normativos - critérios e geral baseados no caráter coercitivo ou não das regras editadas - um critério de caráter formal. Do que precede, decorre, na verdade, a possibilidade de opor dois tipos de estratégias de normatização a partir de uma caracterização sintáxica do objeto que se torna alvo de diferentes classes de normas: aqui, em direito, as relações intersubjetivas, ali, sob o regime da lei moral, religiosa, política, ou ainda no âmbito das deontologias profissionais, dos códigos do savoirvivre etc., diretamente os próprios comportamentos dos sujeitos. Pois o que é prioritariamente pertinente para o direito, como para qualquer gramática, é a relação e não os termos que ela une." 
Seguindo o conselho de Landowski ${ }^{70}$, nesse momento trataremos de traçar como no sistema jurídico brasileiro dá-se essa sucessão de papéis actanciais e quais atores são chamados a preenchê-lo, com vistas a tornar dinâmico o sistema sintáxico que propõe como mecanismo de controle das relações sociais.

O que resta claro é que a determinação de papéis actanciais de destinador legislante e destinador judicante não significa necessariamente que aquele que, precipuamente, ocupa a função legislante deva ser o Poder Legislativo (como já se falou à fartura, o Poder Executivo sistematicamente legisla por meio de medidas provisórias), da mesma forma que aquele que ocupa a função judicante deva ser o Poder Judiciário, que é investido na função precípua de dizer o direito aplicável ao caso concreto.

Como se sabe, por vezes o Poder Legislativo funciona como órgão judicante, notadamente nas intermináveis Comissões Parlamentares de Inquérito, que visam a julgar os atos de improbidade no exercício da função parlamentar, como é o caso da quebra de decoro.

Da mesma forma, para não se dizer que o juiz torna a lei geral e abstrata em norma concreta e pessoal ao proferir decisões, há ao menos um caso, em que é emblemático o poder conferido ao juiz para legislar: a chamada sentença normativa em

${ }^{70}$ LANDOWSKI, Eric. Sociedade Refletida. Cit. p. 79: "Dada a amplitude das análises que implicaria o reconhecimento, por menos sistemático que fosse, dos procedimentos jurídicos efetivos capazes de justificar as hipóteses precedentes, tare-nos-emos aqui a indicar as orientações segundo as quais a pesquisa poderia ser levada adiante. Tratando-se de alicerçar em dados concretos a idéia de que o direito se prende não a uma visão estática e linear, mas a uma dinâmica estrutural fundada na recursividade de um pequeno número de relações elementares de dependência hierárquica, é, ao mesmo tempo, para a organização das vias de recurso - que organizam o mecanismo de sanção das decisões jurídicas - e para os procedimentos de atribuições de competências - que definem as condições prévias ao próprio ato de decisão que, a nosso ver, deveria voltar-se a atenção. Sem desprezar nada do que já é conhecido dos juristas relativamente a cada um desses dois planos considerados separadamente, tratar-se-ia, porém, sobretudo, de explorar os mecanismos e os efeitos de sua colocação em relação, porque é nisso, parece-nos, que reside o elemento motor do sistema." 
decisões trabalhistas coletivas, que dizem respeito às condições gerais de trabalho de determinada categoria de empregados, instaurado por meio de dissídio coletivo ${ }^{71}$

Assim, é menos a clássica separação de poderes em Executivo, Legislativo e Judiciário e mais a questão da superposição de papéis actanciais que permite a constante verificação da eficácia do discurso jurídico, que está sempre revendo suas dicções.

No caso das Comissões Parlamentares de Inquérito, embora possuam autonomia para julgarem os deputados, senadores e vereadores, suas decisões estão submetidas à apreciação do Supremo Tribunal Federal, órgão máximo do Poder Judiciário, guardião da ordem constitucional ${ }^{72}$.

No caso das sentenças normativas, proferidas por juízes do trabalho por ocasião da instauração de dissídio coletivo, após a ação cognitiva do magistrado frente ao caso concreto que lhe é apresentado, este passa à situação de sujeito de estado, submetendo sua decisão à apreciação do Tribunal Superior do Trabalho.

O fato é que toda lei para se tornar eficaz está sujeita à sua adequação a normas hierarquicamente superiores (conforme visto no capítulo I desse trabalho), o que é verificado pelo Poder Judiciário ao aplicá-la ao caso concreto, visando não apenas a determinar, por meio de seu fazer-cognitivo, a adequação da ação do sujeito de direito ao ordenamento jurídico, mas a adequação da própria lei ao sistema que compõe.

Assim, o juiz, pode decidir pela inconstitucionalidade de determinado texto legal, declarando-o inconstitucional (quer seja em ação com efeito apenas entre as partes ou que aproveite a todos, com efeito erga omnes, portanto) e dessa maneira

\footnotetext{
${ }^{71}$ A esse respeito, vide arts. 856 e ss. da Consolidação das Leis do Trabalho (CLT).

72 Para quem acompanhou os mais recentes julgamentos dessa CPIs, veiculadas pelos meios de imprensa à exaustão, era notável a indignação dos julgadores com liminares obtidas junto ao STF para que determinada pessoa não fosse ouvida, para que determinado parlamentar não precisa responder às perguntas dos membros da comissão. A indignação não se justifica, uma vez que é da dinâmica do direito a necessidade de reexame dos atos praticados. Certamente nossos legisladores estão longe de possuírem um conhecimento tão intrincado do sistema jurídico, embora devessem
} 
sancionar negativamente o destinador-judicante que, nesse momento, torna-se sujeito de estado.

Decisões reiteradas no mesmo sentido (seja pela constitucionalidade ou pela inconstitucionalidade da lei) formam o corpo jurídico que denominamos jurisprudencial que, se não têm força de lei (pelo menos não no sistema jurídico brasileira atualmente em vigência), influenciam sobremaneira as decisões posteriores, podendo caminhar para sua sumulação e, posteriormente, pode até ser tornada lei..

No entanto, ao proferir suas decisões, o juiz torna-se sujeito de estado e, a partir daí, terá sua decisão submetida a um destinador-judicante, que revisará em razão de recurso contra aquela decisão a conformidade do fazer-cognitivo não só ao caso concreto, como também às disposições legais, criadas pelo destinador-legislante.

No Estado brasileiro é adotado o princípio do duplo grau de jurisdição, ou seja, a possibilidade de revisão da decisão proferida pelo juiz de primeira instância (juiz singular), pelo juiz de instância superior (Tribunais de Justiça das respectivas Unidade Federadas).

Da mesma forma, o juiz de segunda instância, conforme o caso, pode ter seu fazer cognitivo reexaminado por órgãos hierarquicamente superiores, o STJ (Superior Tribunal de Justiça) e o STF (Supremo Tribunal Federal).

O primeiro é chamado para a verificação da conformidade de decisão anterior, sempre que em sede de recurso alega-se a violação de lei federal ${ }^{73}$ e o segundo é chamado a intervir na condição de destinador-judicante sempre que a violação alegada é contra o texto constitucional ${ }^{74}$, na forma da lei.

\footnotetext{
${ }^{73}$ Para ficar apenas com duas situações, a Constituição Federal assim determina as atribuições do STF, em seu art. 105, III, 'a', 'b' e 'c': “Compete ao Superior Tribuna de Justiça: III - julgar, em recurso especial, as causas decididas, em única ou última instância, pelos Tribunais Regionais Federais, ou pelos Tribunais dos Estados, do Distrito Federal e Territórios, quando a decisão recorrida: a) contrariar tratado ou lei federal, ou negar-lhe vigência; b) julgar válido ato do governo local contestado em face de lei federal; c) der a lei federal interpretação divergente da que lhe haja atribuído outro tribunal."

${ }^{74}$ A competência do STF nesse sentido, vem insculpida no art. 101, III, 'a' a 'd' da Carta Magna: "Compete ao Supremo Tribunal Federal, precipuamente, a guarda da Constituição,
} 
Interessante notar como a organização sintáxica do discurso normativo jurídico brasileiro alia a lei maior do país (Constituição Federal) à atuação do órgão maior do sistema judiciário (Supremo Tribunal Federal), encerrando no âmbito de ambos as pendengas jurídicas, para conferir às relações sociais a segurança jurídica, razão de ser do ordenamento.

Cumpre destacar que atos de Estado contrários aos princípios de direito internacional, tratados e convenções internacionais, podem levar este próprio Estado juridicamente organizado à condição de sujeito de estado em um Tribunal Internacional, em razão de afronta aos direito fundamentais da pessoa humana, em vista da crescente globalização. Essa análise fica para outra ocasião.

Assim, depreende-se que, de fato, a sintaxe gramatical do discurso jurídico guarda relação indissociável com os critérios de intersubjetividade de discretização de papéis, reservando à prática jurídica a responsabilidade de tornar dinâmico o sistema de relações determinado pela sintaxe modal e actoralização das normas de direito.

\section{Casamento e união estável: abordagem semiótica}

O tema central de direito civil que pretendemos explorar nesse trabalho está inserido no campo do direito de família, mais especificamente no que diz respeito ao casamento e a união estável.

Estamos, mais uma vez, diante de Instituições nomeadas pelo direito que dependem de relações interssubjetivas que dão origem a um novo ente: a família. Tratemos de atualizar os termos acima explorados para a explicação do que em direito positivo se entende por sociedades conjugais.

No apêndice, colacionamos os textos de lei do Código Civil de 1916 e de 2002 que tratam do tema e que servirão de corpus para o desenvolvimento das análises que

cabendo-lhe: III - julgar, mediante recurso extraordinário, as causas decididas em única ou última instância, quando a decisão recorrida: a) contrariar dispositivo desta Constituição; b) declarar a inconstitucionalidade de tratado ou lei federal; c) julgar válida a lei ou ato de governo local contestado em face desta Constituição; d) julgar válida lei local contestada em face de lei federal." 
seguem, tendo por objetivo encerrar (dentro das exíguas pretensões desse trabalho) princípios de classificação do direito positivo, com base nos conceitos já explicitados linhas acima.

Considerando que um ramo do conhecimento científico ganha relevância ao criar modelos o mais genéricos e abstratos possíveis, para abarcarem um maior número de situações que pretende subsidiar, passamos à análise semiótica do tema casamento de acordo com o texto de lei do Código Civil de 2002.

A partir daí, trataremos de verificar a eficácia do modelo teórico por meio de uma leitura de adequação dos mesmos princípios adotados cotejando-os com artigos de lei do Código Civil de 1916 que tratam do mesmo tema. Os mesmos métodos devem atingir os mesmos resultados e assim deve ocorrer com a análise, inclusive, de outras legislações, nacionais ou estrangeiras.

Ainda, cabe especificar que dentro do tema casamento, ficaremos com os artigos de lei que compõem o, Título I Subtítulo I, Capítulos I a IX e Título III. O primeiro Título trata do casamento e sua celebração; o segundo título trata do regime patrimonial da sociedade conjugal; o título III trata da união estável.

Falar em casamento é falar, imperiosamente, de relações intersubjetivas uma vez que não se pode imaginar um ato de casar-se consigo mesmo, o que beiraria a psicopatologia, da mesma forma que casar-se com um objeto ou com um semovente pode levar o autor do ato a um divã de psicanálise.

Eis aqui, mais uma vez, a confirmação (um tanto óbvia) de que o direito somente se importa com as relações intersubjetivas dos indivíduos, neste caso, a celebração do casamento e todos os seus efeitos.

Ainda que se espere que o casamento surja por um ato de amor inabalável, que está longe de poder ser apreendido pelo direito, uma vez exteriorizado o desejo de se unir com alguém por meio de casamento há a geração de uma série de conseqüências que possuem primordial importância para o direito positivo.

Ao se casar, cria-se uma nova unidade, que é a sociedade conjugal que, por sua vez vai gerar para os sujeitos uma série de deveres para a sua manutenção. De acordo com o art. 1.566 do Código Civil, in verbis: 
“Art. 1.566. São deveres de ambos os cônjuges:

I - fidelidade recíproca;

II - vida em comum, no domicílio conjugal;

III - mútua assistência;

IV - sustento, guarda e educação dos filhos;

V - respeito e consideração mútuos."

Sendo da ordem do dever-ser, tais prescrições jurídicas vinculam aqueles que dão início à sociedade conjugal. Celebrado o contrato fiduciário entre sujeitos de acordo com as prescrições legais, não cabe mais a eles determinarem o que podem ou não podem fazer dentro do casamento, sob pena de sofrerem as respectivas sanções legais, por haverem frustrado a avença inicial.

Ao agir em desacordo com o previsto em lei, o sujeito dará ensejo à dissolução da sociedade conjugal, por meio de separação ou divórcio, conforme o caso; ao descuidar do sustento, guarda e educação dos filhos pode ser destituído do pátrio poder, de acordo com as circunstâncias do caso. Eis mais relações intersubjetivas que se criam dentro da sociedade conjugal: filiação e parentesco.

É assim que o direito vai se apoderando dos fatos que pertencem ao nível referencial, à /natureza social/ e alçando-os ao nível legislativo, à /cultura jurídica/ que acaba por criar efeito de prevalência em relação aos atos que nomeia. E é, de fato, por meio da sintaxe narrativa que funda o seu discurso.

Por ser isotópico e isomorfo à fala do discurso referencial, o percurso narrativo que se observa é o do sujeito do nível referencial que age em conformidade com o nível legislativo e por isso é considerado por este como /cônjuge/, por ter agido de acordo com as prescrições jurídicas.

Tudo tem início por meio de um contrato fiduciário entre dois sujeitos (os nubentes) que desejam se unir em matrimônio, o que implica formalizar a pretendida 
união de acordo com os preceitos jurídicos que o regulam, de acordo com a produção jurídica.

Os sujeitos são, assim, manipulados mutuamente e por imposição social, para unirem-se de acordo com o ordenamento jurídico e se dão conta que para tanto não basta amar: há a necessidade de se percorrer todo um percurso para se transformar o querer-fazer em poder-fazer. Em suma, a lei cria um papel actancial (cônjuge) e determina a maneira de se obter tal status.

Vejamos o que preceitua o art. 1.514 do Código Civil:

Art. 1.514. O casamento se realiza no momento em que o homem e a mulher manifestam, perante o juiz, a sua vontade de estabelecer vínculo conjugal, e o juiz os declara casados.

Esse é o objeto-valor perseguido pelo sujeito: o casamento. Para atingir esse objetivo e tornar-se sujeito realizado, ele deverá percorrer o percurso estabelecido na própria lei. O capítulo II do Subtítulo I, trata "da capacidade para o casamento", ao passo que o capítulo III trata "dos impedimentos" e o capítulo IV trata "das causas suspensivas".

Veja que já há uma fase veridictória logo no início do percurso narrativo, isso porque, como já se disse, não basta amar, tem que preencher os requisitos legais para se celebrar o casamento.

Que fique claro que aqueles que se unem sem o preenchimento dos requisitos legais praticam ato em desacordo com o ordenamento jurídico e estão excluídos da cultura jurídica.

De acordo com o capítulo II, em suma, para se casar é necessário que se tenha mais de quinze anos, sendo que até os dezoito anos é necessário autorização dos pais; o capítulo III impede que se casem aqueles que mantêm estreitas relações de parentesco ou com o homicida do cônjuge do sobrevivente; e o capítulo IV determina causas que suspendem a possibilidade do casamento, até que fato superveniente venha a ocorrer. 
Temos, portanto, que o indivíduo que quer-ser cônjuge, para poder-ser deverá: ser maior de dezesseis anos; não ser parente próximo do outro; ter regularizado pendências legais de relações anteriores.

Caso se encaixe no modelo actancial do que o discurso jurídico denomina /nubentes/ (vide termo utilizado no art. 1525 do Código Civil), poderá submeter-se a outro percurso narrativo, que se inicia na habilitação para o casamento e se encerra com a efetiva celebração do casamento, conforme veremos a seguir.

No entanto, cumpre salientar que aquele que, mesmo não preenchendo os requisitos legais, por meio de fraude parece-ser o que não é, desencadeia um percurso de sanção que vem previsto no Capítulo VIII do Subtítulo I.

Para conquistar a condição de /cônjuge/ deve o /nubente/ submeter-se a um processo de habilitação para o casamento que se resume, basicamente, a colocar a prova perante a sociedade, que possuem os requisitos para poderem ser cônjuges. Não havendo prova em contrário, o /nubente/ habilita-se para celebrar o casamento e, enfim, entrar em conjunção com seu objeto valor.

No que concerne mais especificamente à celebração do casamento, que vem prevista no Capítulo VI do Subtítulo I, é de se notar e destacar a importância especial que é conferida à publicidade do casamento, que se inicia com as proclamas, que dão conhecimento a todos da sociedade o interesse do sujeito em se casar, que continua com a sua celebração em dia, hora e lugar previamente determinado pela autoridade competente, na sede do Cartório de Registro das Pessoas Naturais, na presença de testemunhas, deixando claro o parágrafo quarto do art. 1534 do Código Civil que “quando o casamento for em edifício particular, ficará este de portas abertas durante o ato.”

Isso parece ser mecanismo do legislador para deixar bem claro que a união entre sujeitos só é reconhecido socialmente e pelo ordenamento jurídico como casamento quando não for espúrio, às escuras, às escusas, conforme já observado no capítulo I dessa dissertação.

Dessa forma, aquilo que é prescrito pelo ordenamento jurídico é euforizado e tornar-se objeto-valor daqueles que desejam agir de acordo com os anseios sociais. 
É a sanção positiva do ordenamento jurídico que busca o sujeito e, para tanto se submete a todo percurso narrativo proposto pelo legislador para atingir seu fim.

E, ao alçar para o discurso jurídico o casamento e regrá-lo minuciosamente, ao mesmo tempo, torna irrelevante, inexistente mesmo aquilo que não nomeia, ou nomeia às avessas, como seria o caso do concubinato, seja em razão de relações adulterinas, incestuosas, etc.

Depois trataremos da voz no discurso e o temor que causa a palavra do legislador nos sujeitos, por hora fiquemos apenas com essa impressão preliminar que basta para deixar claro, na instância por hora explorada, que trata das estruturas semionarrativas dos textos, as diferenças entre essas previsões legais que tratam do casamento, com as previsões legais que regulam a união estável, as quais nos permitimos reproduzir na íntegra a seguir, por serem apenas 05 artigos de lei.

\section{TÍTULO III DA UNIÃO ESTÁVEL}

Art. 1.723. É reconhecida como entidade familiar a união estável entre o homem e a mulher, configurada na convivência pública, contínua e duradoura e estabelecida com o objetivo de constituição de família.

$\S 1^{o}$ A união estável não se constituirá se ocorrerem os impedimentos do art. 1.521; não se aplicando a incidência do inciso VI no caso de a pessoa casada se achar separada de fato ou judicialmente.

$\S 2^{\underline{0}}$ As causas suspensivas do art. 1.523 não impedirão a caracterização da união estável.

Art. 1.724. As relações pessoais entre os companheiros obedecerão aos deveres de lealdade, respeito e assistência, e de guarda, sustento e educação dos fillhos.

Art. 1.725. Na união estável, salvo contrato escrito entre os companheiros, aplica-se às relações patrimoniais, no que couber, o regime da comunhão parcial de bens. 
Art. 1.726. A união estável poderá converter-se em casamento, mediante pedido dos companheiros ao juiz e assento no Registro Civil.

Art. 1.727. As relações não eventuais entre o homem e a mulher, impedidos de casar, constituem concubinato.

Pode-se notar sem maiores dificuldades que já não se trata mais de um percurso a ser percorrido pelo agente para atingir determinado objeto-valor, mas apenas uma espécie de sanção positiva do legislador para aqueles que se uniram sem os requisitos necessários para a celebração do casamento.

No título que cuida da união estável não há a determinação de um percurso, fruto do arbítrio do legislador, mas apenas a previsão de requisitos mínimos para que a convivência pública, contínua e duradoura entre homem e mulher sejam reconhecidas como /não-proibidas/ pelo ordenamento jurídico.

Caso o percurso já operado pelo agente, em desacordo com as previsões legais para a celebração do casamento não esteja também em desacordo com o previsto no art. 1.723 e seguintes do Código Civil, seu percurso será considerado como união estável.

Em suma, no casamento há um percurso previsto pela lei para que a união se inicie ao passo que na união estável, o ato já ocorreu, bastando verificar se afronta ou não as previsões legais que o amoldam.

Partindo da oposição fundamental /prescrições/x/proibições/, temos que o casamento é o prescrito como conduta de acordo com a /cultura jurídica/; já a união estável é o não-proibido pelo ordenamento jurídico; resta aqui uma pergunta: o que seria proibido por lei? A resposta está no art. 1.727 do Código Civil, que define o concubinato.

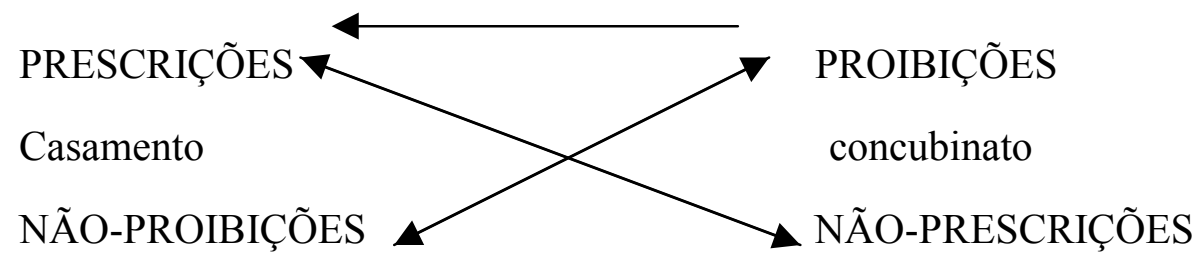

União estável 
Tais resultados homologam-se perfeitamente com as assertivas de E. Landowski, de que a norma jurídica deve ser compreendida como uma sintaxe narrativa que se desenvolve e cria papéis actanciais a serem ocupados pelos sujeitos, muito além, portanto, do mero inventário de norma de condutas sem fluência.

Ao distinguir dois percursos, um para a celebração do casamento e outro bem diverso para o reconhecimento da união estável o legislador opera uma alteração na própria narratividade, que se apresenta como um percurso com foco na ação do sujeito manipulado, no caso do casamento e como percurso com foco na sanção do sujeitomanipulador no caso da união estável.

Façamos agora o cotejo do que foi exposto acima com as previsões que tratam do mesmo tema e que vinham previstas no Código Civil de 1916, para notar a que resultado chegamos e onde se encontrava a união estável naquele momento e de que maneira a verificação jurídica interfere nos movimentos legislativos.

De fato, a distância de mais de 80 anos que separa as codificações faz notar as profundas mudanças sociais e o efeito que causam no ordenamento jurídico, sendo mesmo tarefa do discurso jurídico conferir o que se denomina "juridicidade" para os fenômenos socais que surgem ao longo dos tempos.

Nesse sentido, é notável os capítulos II e III do Subtítulo I que tratam “dos direitos e deveres do marido" e "dos direitos e deveres da mulher", respectivamente. O código de 1916 estabelece uma clara distinção, dentro do papel actancial de /cônjuges/ aos que nomeia como /marido/ e /mulher/, o que foi absolutamente abolido pelo Código de 2002.

No Código de 1916, ao /marido/ era conferido o poder de representação legal da família e do gerenciamento de seu patrimônio, bem como o sustento de todos seus dependentes, da /mulher/, inclusive. 
À mulher era atribuída a função de auxiliar do /marido/, responsável pelas tarefas domésticas e sujeito à aprovação de seu /marido/ a validade dos atos por ela praticados no que concerne a bens e ofícios fora do lar conjugal.

Temos, assim, uma manifesta oposição entre os cônjuges enquanto componentes de uma unidade familiar, o que a tornava, sob a égide do Código Civil de 1916, o que Greimas chamou de actante sintagmático.

Parece que o atual Código Civil, ao abolir as distinções entre os papéisactanciais de marido e mulher (vide Capítulo V que trata “do poder familiar"), tornando tais distinções juridicamente irrelevantes, visa a privilegiar a união daí resultante, ou seja, a unidade familiar que se forma anulando as oposições entre marido e mulher tratando-os igualmente como /cônjuges/ e conferindo aos mesmos igualdades de direitos e obrigações, tornando, enfim a entidade familiar como actante paradigmático.

Como é possível notar, pela sistemática do atual Código Civil, as unidades individuais (Ui - nubentes) transformam-se em unidades partitivas (Up - cônjuges), dando origem, pela comunhão de vontades e de patrimônio a uma totalidade partitiva (Tp - família), que é a responsável pela condução da vida familiar, quer no aspecto patrimonial quer, no aspecto de criação de filhos e colaboração mútua para o sucesso da entidade criada.

Quanto à questão patrimonial, cabe dizer que as Codificações Civis determinam os possíveis regimes de bens entre os cônjuges que vão da separação total de bens à comunhão universal dos mesmos, o que será decidido pelos sujeitos conforme entendam por determinante a união ou distinção do patrimônio para a concussão de sua família.

Ao operar a alteração do valor conferido ao casamento pelos sujeitos tal como abordado no Código Civil de 1916, que carregava forte traço de /individualidade/ ao bem demarcar a obrigação do marido e da mulher, conferindo-lhes atribuições e tratamentos diversos e, com isso, papéis-actanciais bem distintos e valorizá-lo enquanto /união/, notadamente quando abole a distinção anterior de "direitos e deveres do marido e da mulher" ao tratar do tema no art. 1.566 como "deveres de ambos os cônjuges", o Código Civil de 2002 opera a anulação da distinção entre /marido/ e /mulher/ reforçando o papel actancial de cônjuge, homologando-se, portanto com a distinção na sintaxe narrativa. 
Veja que, de acordo com a atual sistemática legal, ambos os cônjuges devem cumprir as mesmas imposições do sujeito-manipulador para não serem sancionados negativamente por desrespeitarem o contrato fiduciário, o dever-fazer unificou-se, reiterando o novo sentido do casamento na nova codificação.

Posto isso, o que se pode observar de maneira ampla é que, não obstante as distinções delineadas acima, tanto o Código Civil de 1916 como o Código Civil de 2002 obedeceram a um mesmo estatuto semiótico de formação discursiva, criando relações entre sujeitos e percursos de aquisição de objetos por meio desses sujeitos.

Se um legislador optou por esse ou aquele percurso, unificou ou simplificou tarefas para o sujeito-manipulado tornar-se sujeito-realizado, bem como operou anulação de papéis actanciais, tais fatos se deveram a posturas ideológicas que contribuíram na maneira como foi atribuído o valor do valor buscado pelos sujeitos.

Tais questões fogem dos domínios do nível narrativo e devem ser analisados a partir da análise do nível discursivo, que atualiza as oposições fundamentais que fundam o texto e permitem o desenvolvimento da narratividade, transformando estados, revestindo-os por meio de temas, figuras e estratégias de enunciação, o que será devidamente explorado no próximo capítulo.

Por fim, é interessante notar que a união estável não era prevista como forma de união conjugal reconhecida pelo ordenamento jurídico quando ainda em vigor o Código Civil de 1916, sendo considerada, portanto, como proibido, em desacordo com o ordenamento jurídico.

Nesse caso, conforme já explorado nesse capítulo, foi por meio da verificação jurídica que tal união passou a ser submetida à análise de validade quando confrontada com a legislação e, com isso conquistando contornos de gramaticalidade jurídica e semanticidade jurídica, o que desencadeou um processo de produção jurídica para sua recepção pelo ordenamento jurídico, criando-se um novo Instituto que incluiu em seu dicionário e que passou a se comportar de acordo com a gramática jurídica. 
Tal fato enaltece o papel criador também da verificação jurídica no discurso jurídico, manipulando o legislador a rever seu discurso e operar nova produção jurídica para abarcar situações que não podem permanecer à margem do direito, o que se homologa com a assertiva de Greimas de que ambos os métodos são essenciais para a criação do discurso jurídico positivo.

Retomando a questão do actante coletivo, é interessante notar que foi justamente em virtude do patrimônio que a união estável passou a ser reconhecida como entidade familiar por nosso ordenamento jurídico.

Com efeito, as primeiras decisões que reconheceram existência jurídica ao que a doutrina denomina concubinato puro, deram-se por meio de ações denominadas 'dissolução de sociedade de fato', ou seja, ações que visavam a dissolução e distribuição do patrimônio daqueles que viviam em concubinato.

Com o tempo, passou-se a reconhecer que não era necessário a mulher ter contribuído diretamente para a compra do patrimônio para que tivesse direitos sobre ele, devendo comprovar que exercia as tarefas domésticas do casal, considerando o pagamento para esses fins como “indenização" por serviços domésticos.

Foi somente com o reconhecimento da união estável pela Constituição Federal (como já foi visto) que tornou-se possível a equiparação da união estável ao casamento, afastando o vínculo patrimonial como traço semântico caracterizador desse tipo de relação.

Cumpre ressaltar que para as relações concubinárias, denominadas pela doutrina como concubinato impuro, permanece a necessidade de participação financeira (direta ou indireta) para fazer jus à participação no patrimônio, com a respectiva propositura de dissolução de sociedade de fato. 


\section{III - A SEMÂNTICA GLOBAL DAS CODIFICAÇÕES CIVIS}

Uma vez determinados os pressupostos semióticos das normas jurídicas, o que se fez com base nos estudos de semiótica narrativa, é hora de emergir à superfície do texto e verificar como as codificações civis, objeto de estudo desse trabalho, tratam de atualizar as estruturas sintáxicas e semânticas do nível sêmio-narrativo por meio da instância da enunciação, recobrindo aquelas estruturas com determinada visão de mundo, ou seja, de acordo com certa postura ideológica.

Se é certo que a pretendida investigação poderia tomar por base a semiótica discursiva, considerando que o se pretende é a análise conjunta de dois discursos distintos (embora guardem estreitas semelhanças entre si, conforme se tornará mais claro com o desenvolvimento da pesquisa) e, mais do que isso, pretendendo-se depreender a semântica global dos textos considerando sua instauração no interdiscurso, os mecanismos puramente semióticos poderiam nos levar a conclusões que não nos interessam nesse momento, ficando afastado aqui o desenvolvimento de uma semiótica do direito, ou seja, do discurso jurídico.

Ainda assim, permanecendo fiel aos parâmetros estabelecidos para a pretendida análise, notadamente no que se refere à intenção de depreender o sentido nos textos por meio dos elementos que ele nos oferece, sem levar em consideração, ao menos a priori, questões que transcendem o texto, tais como dados históricos, biográficos e ontológicos, concebendo a instância da enunciação pelas marcas que dela se observa no enunciado, tratando-a, portanto como instância pressuposta pelo enunciado, a análise será mais frutífera se a enunciação for transportada para o campo da interdiscursividade.

Tal providência é tomada devidamente alicerçada nos estudos de Dominique Maingueneau a respeito da interdiscursividade e apuração da semântica global dos discursos, não por meio de uma sondagem lingüística stricto sensu, que certamente nos permitiria apenas observar o que se convenciona chamar de intertextualidade mostrada, mas por meio de recursos que permitem apurar o texto como um todo de sentido, que dialoga com outros textos, os quais incorpora constitutivamente. 
É no ramo da pragmática que Maingueneau insere suas reflexões ${ }^{75}$ :

"Fazendo isso, inscrevemo-nos basicamente no movimento de fundo que domina a reflexão sobre a linguagem há pelo menos uma década, o movimento da 'pragmática', que pretende precisamente articular no ato verbal enunciado e enunciação, linguagem e contexto, fala e ação, instituição lingüística e instituições sociais... Certamente, nosso projeto opera num nível diferente, o do discurso, mas ele fica ligado a essa corrente que atravessa o conjunto do campo das ciências humanas."

Considerando que nosso corpus insere-se justamente dentro do campo das denominadas ciências sociais, trataremos dessa maneira o nível discursivo dos textos em análise.

$\mathrm{Da}$ análise do discurso de linha francesa que sustenta nossos pressupostos, trataremos apenas daqueles necessários e suficientes para alicerçar sua homologação com a análise do discurso jurídico, tarefa não só de levantamento da teoria, mas também de adaptação ao discurso a ser estudado, uma vez que tais conceitos são erigidos de análise de textos literários e religiosos.

No entanto, insistindo na questão de que, se os modelos aqui explorados são eficazes para esse ou aquele discurso, devem funcionar também para a abordagem do discurso jurídico, uma vez que todo texto é um todo de sentido e as distinções de gênero, estilo e abordagem não podem se tornar entraves para sua adaptação para qualquer tipo de manifestação discursiva.

Isso posto, cumpre determinar que para a análise a ser desenvolvida interessa mais proximamente os conceitos de interdiscursividade e seu desdobramento em universos, campos e lugares discursivos, bem como a noção de polifonia e da semântica global dos discursos.

\footnotetext{
${ }^{75}$ Maingueneau, Dominique. Gênese dos discursos. Criar edições. Curitiba. 2005. p. 24-25.
} 
Conforme já determinado linhas acima, a interdiscursividade aqui tratada relaciona-se com a noção da heterogeneidade constitutiva inerente a qualquer gênero de texto, partindo do pressuposto de que a instância da enunciação determina seu enunciado na relação que estabelece com outros textos, que participam da sua constituição.

Para aclarar tal conceito e torná-lo mais factível, cumpre determinar o conceito de interdiscursividade substituindo-o pela tríade universo discursivo, campo discursivo e espaço discursivo ${ }^{76}$.

Universo discurso é o conjunto de todas as formações discursivas possíveis que integram e interagem entre si e que, em que pese sua finitude, não é possível e até mesmo seria de pouca utilidade inventariá-los, uma vez que a importância de sua delimitação está mais na possibilidade de, a partir daí, distinguir entre os possíveis campos discursivos ${ }^{77}$.

Campo discursivo, por sua vez, compõe um conjunto de formações discursivas que estabelecem entre si relação de concorrência ${ }^{78}$ e que não se mostra evidente prima facie, mas é fruto das hipóteses formuladas pelo analista.

\footnotetext{
${ }^{76}$ Maingueneau, Dominique. Gênese dos discursos. Cit. p. 35.

77 Maingueneau, Dominique. Novas tendências em análise do discurso. Pontes. Campinas. 1997. p. 116.

${ }^{78}$ Maingueneau, Dominique. Gênese dos discursos. Criar edições. Curitiba. 2005. p. 36, vai bem delimitar o sentido de "concorrência", para o autor esse termo "deve ser entendido de maneira mais ampla; inclui tanto o confronto aberto quanto a aliança, a neutralidade aparente etc...entre discursos que possuem a mesma função social e divergem sobre o modo pelo qual ela deve ser preenchida. Pode-se tratar do campo político, filosófico, dramatúrgico, gramatical etc...Esse recorte em 'campos' não define zonas insulares; é apenas uma abstração necessária, que deve permitir abrir múltiplas redes de trocas. Sabe-se que Michel Sarres fez-se apóstolo dessa colocação em comunicação generalizada, lendo uma Fábula de La Fontaine através da grade da matesis cartesiana ou a 'Chronique dês Rougon-Macquart' através dos conceitos da termodinâmica do século XIX.”
} 
No caso em análise podemos estabelecer relações entre campos discursivos que tratam do 'comportamento humano', inserindo nossos estudos no campo das ciências sociais em geral, tais como a sociologia, ciência política, antropologia, filosofia e ética.

Dentro do campo discursivo denominado discurso jurídico é o lugar da instauração do conflito entre as codificações, determinando o lugar discursivo (que complementa a tríade que compõe a noção de interdiscurso ${ }^{79}$ ) que cada uma delas ocupa e a especial relação que estabelecem entre si, verificando o discurso do outro no discurso enunciado.

É bom advertir que a polêmica é instaurada pelo analista, com vistas a tirar proveito do cotejo entre os textos em análise, buscando elucidar que tipos de relação estabelecem entre si, ou seja, como a polêmica é instaurada ${ }^{80}$.

No caso em tela, por meio da configuração de dois lugares discursivos distintos, um que se refere ao Código Civil de 1916 e outro que se refere ao Código Civil de 2002 procuraremos estabelecer as restrições semânticas empenhadas por tais discursos e como, dialogicamente, estabelecem seus respectivos sentidos.

Falar em dialogismo implica compreender o conceito de polifonia que o "Dicionário de Análise do Discurso" assim define ${ }^{81}$ :

"Termo emprestado da música, que alude ao fato de que os textos veiculam, na maior parte dos casos, muitos pontos de vista diferentes: o autor pode fazer falar várias vozes ao longo do seu texto (...) A polifonia

\footnotetext{
${ }^{79}$ Conforme, Maingueneau, Dominique. Gênese dos Discursos. Cit. p. 35.

${ }^{80}$ Nesse caso, buscamos apoio no seguinte trecho de MAINGUENEAU, Dominique. Novas tendências em análise do discurso. cit. p 117: “O 'espaço discursivo', enfim, delimita um subconjunto do campo discursivo, ligando pelo menos duas formações discursivas que, supõese, mantêm relações privilegiadas, cruciais para a compreensão dos discursos considerados. Este é, pois, definido a partir de uma decisão do analista, em função de seus objetivos de pesquisa." 81 Charaudeau, Patrick/ MAINGUENEAU, Dominique. Dicionário de Análise do Discurso. Contexto. São Paulo. 2004. p-384.
} 
parece funcionar em vários níveis de análise (...) a polifonia da análise do discurso é um fenômeno de fala e, nesse sentido, concreto."

Ora, o Código Civil de 2002 se vale do mesmo "esqueleto" do Código Civil de 1916 (que, por sua vez, moldou sua estrutura tal como a do Código Alemão - BGB, norteando-se pelos princípios que informaram o Código de Napoleão) e é possível se encontrar na atual codificação muito do que se lia no antigo estatuto e, nos pontos em que se lêem prescrições legais distintas, instaura-se a polêmica entre os códigos, permanecendo a relação dialógica entre eles.

Ocorre que nesses casos a relação dialógica com o outro é abafada criando-se o efeito de sentido de discurso monofônico, como meio de esconder a própria vulnerabilidade constitutiva do discurso.

Maingueneau $^{82}$, ao analisar os provérbios vai afirmar o que segue:

“Considerado sob este ângulo, o provérbio representa um enunciado limite: o 'locutor' autorizado que o valida, em lugar de ser reconhecido apenas por uma determinada coletividade, tende a coincidir com o conjunto de falantes da língua, estando aí incluído o indivíduo que o profere. Esse último toma sua asserção como o eco, a retomada de um número ilimitado de enunciações anteriores do mesmo provérbio. Verdades imemoriais por definição, os provérbios, com muita justiça, fazem parte do dicionário da língua. Não é possível, em sentido estrito, citar um provérbio, relata-lo: pode-se apenas referi-lo a um Outro absoluto no qual estaríamos incluídos por direito.”

Guardadas as devidas proporções, esse tipo de raciocínio pode ser aplicado para a análise da norma jurídica, uma vez que a figura abstrata do legislador nada mais é que a de um locutor que busca validade de seu dito no consenso que se estabelece entre as unidade integrais que compõem o actante coletivo que toma coro nas decisões do

\footnotetext{
${ }^{82}$ Maingueneau, Dominique. Novas tendências em análise do discurso. cit. p- 76.
} 
parlamento, composto por indivíduos eleitos pelo povo para fazerem valer seus desejos coletivos transformados em $1 \mathrm{ei}^{83}$.

Antes de seguir adiante, necessário se faz a definição do que se entende por discurso normativo, tomando por base não uma definição pré-determinada por este ou aquele autor necessariamente, mas de acordo com o que nossa pesquisa nos permite determinar, de acordo com os dados levantados até aqui.

\section{Assim, podemos considerar os seguintes traços característicos do discurso jurídico:}

- possui linguagem própria: como se viu ao longo de todo capítulo II desse trabalho, as línguas naturais não permitem apenas falar das coisas cuja existência são evidentes, mas também falar de coisas que pertencem a um certo segundo grau da linguagem, que criam determinadas visões de mundo na medida em que são enunciados.

Parece que qualquer falante da língua portuguesa, por exemplo, sente-se habilitado a comentar temas relacionados ao discurso jurídico, mas, quando o fazem, a impressão que se dá é sempre de certo distanciamento, temor e dúvida no que se refere ao efetivo significado do termo na sua compleição legal.

É assim, por exemplo, que um funcionário que se sente prejudicado por seu 'patrão', diz que vai 'levá-lo ao Ministério do Trabalho', quando, aquele que tem conhecimento da linguagem e do meio ambiente jurídico, sabe que não está correta esta afirmação, porque o Ministério do Trabalho é órgão do Poder Executivo e a esfera competente para solucionar conflitos de interesse oriundos de relações empregatícias é, na realidade, a Justiça do Trabalho.

\footnotetext{
${ }^{83}$ Aqui é de relevo a retomada da noção de actante coletivo, cunhada por Greimas e que foi abordada de perto no Capítulo II desse trabalho. Com efeito, as legislações são fruto de uma voz compartilhada, representada pelos políticos, a quem o povo delega o dever-poder de criar as regras que regulamentam as relações em sociedade. É típico caso de actante paradigmático, partindo-se de uma unidade integral (povo) para uma unidade partitiva (parlamentares), que constitui uma Totalidade partitiva (parlamento), que se torna totalidade integral (expressão da vontade do povo).
} 
- refere-se a relações humanas: como também parece ter restado claro no capítulo II desse trabalho, o discurso normativo presta-se a regulamentar as relações intersubjetivas, sendo assim, é do universo humano que retira seu substrato fundamental.

Às leis da física cabem regrar as relações necessárias que derivam da natureza das coisas, como seria o caso de estabelecer as leis da cadeia alimentar, por exemplo. Já ao discurso normativo importa os atos efetivamente realizados pelos indivíduos em sociedade, relacionando-se, portanto, ao cotidiano da vida em sociedade.

é da ordem do dever-ser: como já ficou bem claro a esta altura dos trabalhos, o discurso normativo não tem como finalidade apenas descrever comportamentos humanos ou orientar como seria o modo de vida mais adequado em sociedade.

De fato, o que o discurso normativo encerra é uma série de comandos que, por convenção, vinculam as ações humanas e impõem uma maneira de relacionamento social, a partir da concretização em preceitos legais das relações humanas possíveis e observáveis.

E, conforme visto, é o caráter coercitivo das normas, que apóiam todo o discurso jurídico, que distingue o discurso normativo-jurídico das normas morais e religiosas.

- é ideológico: a opção ideológica, via de regra, está sempre interferindo na produção dos mais diversos discursos, quer sejam eles literários, políticos, filosóficos ou sociológicos. Com o discurso normativo não poderia ser diferente.

O legislador, dentro de valores culturais que interagem em sociedade, torna discurso jurídico aquilo que determina relevante para o bem-estar social. É assim que um governo que privilegia o Estado desconcentrado e enxuto, vai criar mecanismos jurídicos para facilitar seu interesse na privatização dos serviços públicos, ao passo que um governo que tem noção de Estado concentrado e clientelista, vai incentivar criação de leis para a proteção do indivíduo pelo Estado. 
Com efeito, modernamente, uma nação é reconhecida como Estado a partir do momento em que fundamenta seus comandos por meio de determinado sistema legal.

Basta olhar para dados recentes e recorrentes para se notar, por exemplo que, após a invasão norte-americana no Iraque, logo foi determinada a criação de um corpo político para que se desse vida a uma nova Constituição para regrar a nova existência política daquele país.

Não foi por outro motivo que Napoleão, após a queda da bastilha, determinou e presidiu os trabalhos para dar vida à Constituição Federal daquele país, como forma de firmar a ruptura com o governo absolutista e a ascensão ao poder da burguesia.

\section{Semântica global das codificações civis}

Recuperando o que foi dito em linhas acima, após distinguir o discurso jurídico dos demais discursos com os quais dialoga, dando uma noção de norma jurídica e do dinamismo do ordenamento jurídico, passando pela definição de conceitos de análise de discurso diretamente aplicáveis no caso em estudo, tais como o de universo, campo e lugar discursivo, heterogeneidade constitutiva e polifonia, é hora de se buscar a semântica global de ambos os códigos e colocá-los em confronto, a fim de se apreender como um discurso se estabelece na relação que mantém com o outro.

Dominique Maingueneau em sua obra “Gênese dos Discursos”, propõe um método de análise da semântica global do texto por meio do estudo de seus componentes (tópicos) que, como alerta o autor, não se trata de um modelo genético no qual o enunciador vai escolher o tópico inicial, a forma literária, em seguida o vocabulário, etc. ${ }^{84}$

\footnotetext{
${ }^{84}$ MAINGUENEAU, Dominique. Gênese dos Discursos. Cit. 80-81.
} 
De fato, o autor deixa bem claro que os tópicos de análise dos textos que propõe se prestam a ilustrar a variedade de dimensões que devem ser consideradas para a caracterização da semântica global do texto, não havendo o que proíba, por exemplo, isolar um tópico de outros ou distribuí-los da maneira que for mais produtiva para a análise que se pretende.

Partindo desse princípio, a análise dos tópicos que determinam a semântica global das codificações em análise nesse trabalho obedecerá a seguinte ordem: intertextualidade, modo de coesão, modo de enunciação, dêixis enunciativa, estatuto do enunciador e do destinatário, tema e vocabulário.

Elegeu-se o tema Direito de Família que, como o próprio termo sugere, regra as relações amorosas entre homem e mulher com o objetivo de constituir família, matéria esta que, desde as civilizações mais remotas, recebeu especial cuidado dos legisladores, quer por sua importância na constituição do Estado, quer por ser fonte interminável de desavenças.

Por meio da análise da semântica global, busca-se depreender as restrições semânticas que estão presentes nos discursos e que bem delimitam seu campo discursivo e seu modo de apreensão da realidade por meio de textos.

A análise que segue dará preferência às previsões legais dispostas no Código Civil de 2002 e, em virtude do primado da interdiscursividade, qualquer comentário feito sobre ele recai também, obliquamente, sobre o Código Civil de 1916, como já advertira Maingueneau quando tratou do discurso humanista devoto e jansenista em "Gênese dos Discursos"

${ }^{85}$ Com efeito, MAINGUENEAU, Dominique. Gênese dos Discursos. CIt 81 alerta em seu estudo que "como se trata apenas de ilustrar, seremos alusivo e, para não alongar inutilmente a apresentação, privilegiaremos o discurso humanista devoto; em virtude do primado do interdiscurso, qualquer comentário feito sobre ele recai também, obliquamente, sobre o discurso jansenista." Isso porque, ao longo de sua análise, o autor confronta o discurso jansenista com o discurso humanista-devoto, formas de expressão de devoção conflitantes que, como esclarece Maingueneau nota de rodapé (80) da pág. 72 da obra "Sem entrar em detalhes, por detrás do conflito entre humanismo devoto e jansenismo, encontram-se certos aspectos do conflito 


\subsection{Intertextualidade}

A intertextualidade pode ser concebida de duas formas, intertextualidade interna e intertextualidade externa ${ }^{86}$. A intertextualidade interna refere-se à incorporação de discursos que pertencem ao seu campo discursivo, ao passo que a intertextualidade externa refere-se à incorporação de textos de outros campos discursivos adjacentes.

Sob esse aspecto temos que tanto o Código Civil de 1916 quanto o Código Civil de 2002 constituem-se pelas relações que estabelecem com Codificações tradicionais que determinam sua forma e, de certo modo, seu conteúdo.

É assim que as codificações aqui tratadas seguem tradições enraizadas no discurso jurídico que buscam a consolidação de institutos do direito civil com base na tendência de, com base nas lições de direito civil, criar codificações com a intenção de tornar positivo aquele direito que já fora positivado na Roma Antiga e que se restabeleceu a partir do século XVII.

Nesse aspecto, observam-se traços do que se conceitua em análise do discurso como heterogeneidade mostrada, uma vez que ambas codificações tomam como base a divisão de temas diretamente inspirados na construção do Código Civil alemão, que determinou a divisão dos temas das codificações em parte geral e parte especial.

Para além da intertextualidade interna, importa dizer que o Código Civil de 2002 é formação discursiva que privilegia o conceito de culturalismo, ao passo que o Código de 1916, influenciado pelo formalismo lógico de seu tempo procura manter o sistema normativo longe das 'contaminações' que uma abordagem social poderia conferir ao fenômeno jurídico-positivo.

inaugural e exemplar entre aristotelismo e platonismo. As afinidades semânticas entre o neoplatonismo e o jansenismo são muito patentes...No detalhe, as coisas são extremamente complexas, não há dúvida, mas a inscrição desses dois discursos no espaço metafísico grego é inegável, mesmo se os conteúdos investidos são completamente diferentes.

${ }^{86}$ MAINGUENEAU, Dominique. Gênese dos Discursos. Cit. 81-83. 
Isso significa dizer que a atual codificação civil não se prende a excessivos formalismos legais como construtores de uma determinada realidade, tornando a norma jurídica uma espécie de fôrma à qual deve se adaptar a vida social.

Bem diferente do Código anterior que, inspirado pelo positivismo que arrebatou os meandros jurídicos pátrios no final do século XIX, além de manifesta influência do Código Napoleônico, buscava prescrever formas ideais de convívio social, impondo-as à sociedade.

Foi assim que o Código de 1916, no que concerne ao casamento, rompendo com a tradição naturalista, deixou de considerar como de acordo com o ordenamento jurídico qualquer forma de união entre homem e mulher que não o casamento civil, relegando à margem do sistema jurídico o até então chamado "casamento de fato", que era assim considerado não por se revestir das formalidades legais, mas porque naturalmente aquela união entre homem e mulher só poderia ser considerada casamento.

Assim, temos que o Código Civil em vigor remete constantemente à noção de /sociabilidade/ ao passo que o Código Civil anterior prezava pelo /racionalismo/, fonte da relação intertextual interna que mantêm respectivamente com os recursos desta e daquela escola de pensamento do fenômeno jurídico.

Preliminarmente, traçando um paralelo com os estudos de Maingueneau sobre o discurso jansenista e humanista devoto, poderíamos dizer que o Código Civil de 2002 aproxima-se do humanismo devoto, uma vez que aceita outras concepções de direito que não apenas aquelas enraizadas pela tradição jurídica, ao passo que o Código Civil de 1916 aproxima-se do jansenismo por não admitir a existência de outra realidade jurídica senão aquela prevista em lei.

Certamente esta diferença de trato foi preponderante para a recepção pelo ordenamento jurídico do Instituto da união estável, fruto da realidade social e não de construção científica, como o é o casamento civil.

Vale dizer, antes de ser determinado por lei, o casamento civil simplesmente não existia, tornando-se obrigatório após sua criação por lei, ao passo que a união estável, como casamento de fato, sempre existiu, havendo notícias de tal instituto desde o antigo Império Romano. 
Observe que o Código de 2002 não nega o casamento civil do Código de 1916, apenas opera alterações pontuais com vistas a aproximá-lo da realidade social, com a noção de /união/ advinda do casamento, afastando-o da noção de /individualidade/ reforçada na codificação anterior ${ }^{87}$.

Certamente não foi assim que operou o legislador da primeira codificação civil que não admitia a pluralidade de relacionamentos amorosos entre sujeitos pelo mero intuito de unirem-se, mas sim pelo efetivo papel que cumpriam na sociedade então formada em virtude de laços afetivos.

No decorrer da análise, sempre que possível retomaremos esta aproximação do estudo das codificações com as lições de Maingueneau sobre o discurso jansenista e humanista devoto, até mesmo para validar a eficácia desta linha teórica de apreensão da semântica discursiva.

\subsection{Modo de coesão}

Pelo modo de coesão determina-se como a estrutura do discurso se constitui internamente. Traçando um paralelo com a literatura, em especial com a obra de Camões, observa-se que sempre que seus poemas tratam de temas nobres são estruturados de maneira rígida, em versos decassílabos que formam sonetos.

Já ao abordar temas populares o poeta abre mão daquela rigidez e se vale de redondilhas de forma livre, sendo justamente esse trato sintático e sua recorrência que dá coesão interna aos seus textos, conforme é possível observar confrontando os seguintes poemas do autor:

80

Alma minha gentil, que te partiste

tão cedo desta vida, descontente, repousa lá no Céu eternamente, e viva eu cá na terra sempre triste.

\footnotetext{
${ }^{87}$ conforme elucidado quando tratamos do instituo no capítulo II desse trabalho.
} 
Se lá no assento etéreo, onde subiste, memória desta vida se consente, não te esqueças daquele amor ardente que já nos olhos meus tão puro viste.

E se vires que pode mercer-te algua cousa a dor me ficou da mágoa, sem remédio, de perde-te,

roga a Deus, que teus anos incurtou, que tão cedo de cá me leve a ver-te, quão cedo de meus olhos te levou.

Leva na cabeça o pote, o texto nas mãos de prata, cinta de fina escarlata, saínho de chamalote; traz a vasquinha de cote, mais branca que a neve pura; vai fermosa, e não segura.

Descobre a touca a garganta, cabelos de ouro o trançado, fita de cor de encarnado, tão linda que o mundo espanta; chove nela graça tanta que dá graça à fermosura; vai fermosa, e não segura. 
De volta à análise das codificações, observa-se que ambas possuem aparentemente o mesmo modo de coesão, isto porque compostos por artigos de lei que se subdividem, conforme o caso, em parágrafos, incisos e alíneas.

O artigo de lei pode ser definido como uma unidade básica de lei, ao passo que os parágrafos abordam temas periféricos, é escrita marginal que serve para seccionar a exposição central do artigo.

Já os incisos e as alíneas servem, conforme o caso, para elencar, dividir o disposto no caput ou em cada parágrafo.

Essa estrutura sintática decorre da técnica legislativa, conjunto de preceitos que orientam a elaboração racional da lei visando à simplificação quantitativa e qualitativa do material legislativo, sendo que nas leis não há palavras inúteis e cada termo possui um significado jurídico específico, em vista do discurso jurídico ser monossêmico por natureza.

No entanto, a par da aparente identidade de apresentação dos textos jurídicos entre as codificações em cotejo, temos um acervo muito mais amplo de prescrições legais no que concerne ao casamento na codificação de 1916 do que a que se observa na codificação de 2002 .

Peguem-se os Capítulos II e III do Código Civil de 1916, que tratam, respectivamente "Dos Direitos e Deveres do Marido" e "Dos Direitos e Deveres da Mulher". São vinte e dois artigos de lei que pretendem bem delimitar o modo de ação dos cônjuges na relação conjugal.

Como alertado no item anterior, referida codificação preza pelo excesso de apego aos formalismos legais, pretendendo que nenhuma situação possível e desejável em sociedade seja descuidada pelo sistema legal.

Assim, preocupa-se excessivamente em determinar todas as situações em família e maneira como deverá-ser o comportamento dos sujeitos uns em relação aos outros. Ao expressar-se discursivamente desse modo, dá maior relevo aos traços de 
/individualidade/, como que criando uma série rígida de normas de conduta que, se desrespeitadas, levarão o indivíduo a suportar as indesejáveis conseqüências das sanções legais pertinentes.

Mais do que isso, ao "engessar" o modo de ação dos indivíduos em sociedade, afasta-se da própria realidade que visava a regrar, tornando o casamento uma união tensa, cuja preocupação maior está em fazer a sua parte para poder exigir que o outro faça o mesmo e não a de se constituir uma união harmoniosa que dará origem a uma família harmônica da mesma forma.

Em suma, temos que o Código Civil de 1916, ao optar por um sistema fechado e exaustivo de normas que regram o instituto do casamento, por meio desse modo de coesão faz ressoar um discurso individualista e em desacordo com a efetiva constituição de uma sociedade conjugal em pé de igualdade.

Já o Código Civil de 2002, ao eliminar os capítulos que tratavam do "Direito e Deveres do Marido e da Mulher" e editar em seu artigo 1.566 normas concernentes ao dever de ambos os cônjuges, opera flagrante redução textual (22 artigos "transformados" em apenas um artigo de lei) e com isso privilegia a união conjugal e o dever igualitário dos casados, traçando, em linhas gerais, o que deles se espera (fidelidade recíproca, vida em comum, no domicílio conjugal, mútua assistência, sustento guarda e educação dos filhos, respeito e considerações mútuos).

Veja que já não se trata mais de regrar exaustivamente o modo de agir do homem e da mulher enquanto componentes da sociedade conjugal, mas de dar o contorno do que deles se espera para darem vida a uma união consistente, para a criação de uma família também consistente, na qual não pode faltar afeto, amparo, sem diferenças de condições entre seus membros. 
Abrindo mão do regramento rigoroso das condutas dos cônjuges, pretende adequar-se mais facilmente à realidade social que visa a regrar, sendo cediço que hodiernamente não há distinções de ordem econômica e intelectual entre homens e mulheres, sendo a guerra dos sexos uma questão muito mais ideológica e de poder do que fática.

Com isso reforça a possibilidade de permanecer por maior tempo em vigência, porque é difícil conceber tal transformação social que passe a entender como desnecessário no casamento a fidelidade, a vida em comum, o respeito mútuo, etc.

De outra banda, o Código Civil de 1916 foi perdendo sua eficácia na medida em que suas prescrições demonstravam-se afastadas da realidade social que vinha se delineando, não havendo mais sentido na distinção entre homem e mulher dentro da sociedade conjugal.

Há tempos não faz mais sentido atribuir exclusivamente ao homem o dever de “prover a manutenção da família, guardada as disposições dos arts.” 275 e 277 (art. 233, IV do Código Civil de 1916) e relevar a mulher a função de "colaboradora do marido nos encargos de família, cumprindo-lhe velar pela direção material e moral desta.” (art. 1.565, parte final do mesmo diploma legal).

No entanto, não há como se negar que o legislador da nova Codificação Civil, ao optar por esta forma de construção legal (CODIFICAÇÂO), buscou bem determinar os conceitos gerais de direito civil que visa a regrar.

Assim, nesse sentido, não rompeu inteiramente com a tradição anterior procurando pulverizar o regramento das instituições civis por meio de leis esparsas que, ao longo do período de vigência do Código Civil de 1916, vinham traçando novas perspectivas para o direito civil, notadamente para o direito de família e sucessões.

Aliás, é uma reivindicação daqueles que se opõem à tradição de promulgação de codificações a maior efetividade de se regulamentar as relações humanas por meio de micro-universos normativos, como seriam exemplos o Código de Defesa do Consumidor, o Estatuto do Idoso, Estatuto do Torcedor, etc.. 
No entanto, tal tendência não é a observada no sistema legal vigente no Brasil, que permanece conforme a tradição clássica de contar com um texto exaustivo para orientar a maneira de regrar a vida em sociedade.

Temos, portanto, as codificações civis como textos "exaustivos" que procuram regrar todas as situações possíveis em sociedade, notadamente as questões já consolidadas, guardando espaço para as leis esparsas para tratar de questões pontuais, ou seja, apenas para 'modernizar' conceitos solidificados nas codificações a fim de reaproximá-los da realidade social.

Sob uma abordagem de oposição semântica fundamental, pode-se propor que as codificações são textos que afirmam a /concentração/, ao passo que as leis esparsas são a negação dessa concentração, ao se definirem como legislação pontual.

A partir daí, pode-se propor o seguinte esquema de oposições fundamentais:

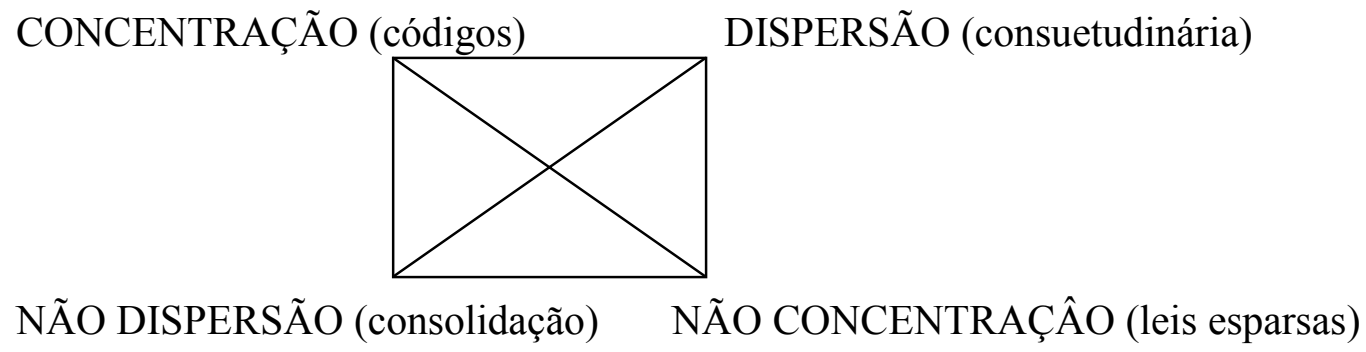

A partir desse esquema, além do que se propõe a tratar nesse trabalho, ou seja, a análise interdiscursiva das codificações em apreço, é possível se estabelecer uma distinção entre as nações que estruturam seu discurso jurídico por meio de codificações, como é o caso do Brasil, e aqueles países que tomam por base os costumes de sua nação, países que se filiam ao que se entende por common law, ou seja, a lei do homem médio, a lei do caso concreto. 
Nesse último caso, o conceito de justiça atrelado ao direito está mais próximo à análise de justiça que se depreende do caso concreto, erigindo daí uma noção de lei dispersa, em oposição ao sistema de leis concentrada adotado pelos países que apóiam seu sistema jurídico em codificações exaustivas.

A consolidação desses costumes seria o caminho para a produção legislativa com base na análise dos casos concretos ou ao menos, à moda inglesa, à catalogação dos assim chamados 'precedentes de corte' que pode ser caminho semelhante ao que, pela via reversa, o Direito Pátrio adota, ao caminhar para o reconhecimento das ditas 'súmulas vinculantes', como forma de fazer cessar a constante busca do judiciário para tratar de questões que já tem sedimentadas as decisões dos Tribunais do Estado a respeito do tema.

Saliente-se que no Brasil já convivemos com Consolidações Legislativas, cujo exemplo maior são as Consolidações das Leis do Trabalho, CLT, além de enunciados dos Juizados Especiais Cíveis e Criminais que caminham praticamente para a consolidação das práticas judiciárias.

Para concluir, em que pese a diferença de tratamento jurídico das codificações em apreço, no que se refere à preocupação de esgotar formalmente todas as possibilidades de vida em sociedade contida no Código Civil de 1916, ao passo que o Código Civil de 2002 abre mão dessa pretensão, cria a noção não apenas de "normas abertas" e "normas fechadas", mas de "sistema legal aberto" e "sistema legal fechado" que pode ser atribuído a cada uma das codificações.

Mais uma vez aqui, nota-se flagrante semelhança à concepção de mundo jansenista do Código Civil de 1916 e à concepção de mundo humanista devoto do Código Civil de 2002, que abre espaço para a recepção do instituto da união estável em seu bojo. 


\subsection{Modo de enunciação}

O modo de enunciação é uma maneira particular de dizer o que se torna texto. Não é porque o texto é escrito que nele não se possa notar uma voz, um modo de tornar discurso o pensamento e isso por meio de um certo modo peculiar do sujeito linguajeiro manifestar-se.

Ao manifestar-se discursivamente dessa ou daquela maneira o sujeito passa a determinar certo modo de ser, seu ethos. Pegue-se uma canção de protesto de Chico Buarque de Holanda e uma de um conjunto Punk, como Sex Pistols.

\section{ApesarDe Você}

\section{Chico Buarque}

\section{Composição: Chico Buarque}

(Crescendo) Amanhã vai ser outro dia x 3

Hoje você é quem manda

Falou, tá falado

Não tem discussão, não.

A minha gente hoje anda

Falando de lado e olhando pro chão.

Viu?

Você que inventou esse Estado

Inventou de inventar

Toda escuridão

Você que inventou o pecado

Esqueceu-se de inventar o perdão.

(Coro) Apesar de você

amanhã há de ser outro dia. 
Eu pergunto a você onde vai se esconder

Da enorme euforia?

Como vai proibir

Quando o galo insistir em cantar?

Água nova brotando

E a gente se amando sem parar.

Quando chegar o momento

Esse meu sofrimento

Vou cobrar com juros. Juro!

Todo esse amor reprimido,

Esse grito contido,

Esse samba no escuro.

Você que inventou a tristeza

Ora tenha a fineza

de "desinventar".

Você vai pagar, e é dobrado,

Cada lágrima rolada

Nesse meu penar.

(Coro2) Apesar de você

Amanhã há de ser outro dia.

Ainda pago pra ver

O jardim florescer

Qual você não queria.

Você vai se amargar

Vendo o dia raiar

Sem lhe pedir licença.

E eu vou morrer de rir

E esse dia há de vir

antes do que você pensa. 
Apesar de você

(Coro3)Apesar de você

Amanhã há de ser outro dia.

Você vai ter que ver

A manhã renascer

E esbanjar poesia.

Como vai se explicar

Vendo o céu clarear, de repente,

Impunemente?

Como vai abafar

Nosso coro a cantar,

Na sua frente.

Apesar de você

(Coro4)Apesar de você

Amanhã há de ser outro dia.

Você vai se dar mal, etc e tal,

La, laiá, la laiá, la laiá......

\section{GodSave The Queen}

Sex Pistols

\section{Composição: Indisponível}

God save the queen

Her fascist regime

It made you a moron

A potential $\mathrm{H}$ bomb

God save the queen

She ain't no human being

There is no future 
In England's dreaming

Don't be told what you want

Don't be told what you need

There's no future

No future no future for you

God save the queen

We mean it man

We love our queen

God saves

God save the queen

'cos tourists are money

And our figurehead

Is not what she seems

Oh God save history

God save your mad parade

Oh lord God have mercy

All crimes are paid

When there's no future

How can there be sin

We're the flowers

In the dustbin

We're the poison

In your human machine

We're the future

Your future

God save the queen

We mean it man

We love our queen

God saves 
There is no future in England's dreaming

God save the queen

We mean it man

There is no future

In England's dreaming

No future for you

No future for me

No future no future for you

\section{God Save The Queen (tradugão)}

Sex Pistols

Composição: Indisponível

Deus salve a rainha

$\mathrm{O}$ regime fascista

Fez de você um retardado

Bomba-H em potencial

Deus salve a rainha

Ela não é um ser humano

Não há futuro

Nos sonhos da Inglaterra

Não diga o que você quer

Não diga o que você precisa

Não há futuro, não há futuro

Não há futuro para você

Deus salve a rainha

Nós queremos dizer isso, cara 
Nós amamos nossa rainha

Deus salve

Deus salve a rainha

Porque turistas são dinheiro

Nossa revolta

Não é o que ela parece

Oh, Deus salve a história

Deus salve a nossa parada louca

Oh, Senhor Deus tenha piedade

Todos os crimes são pagos

Quando não há futuro

Como podemos estar em pecado?

Nós somos as flores no chiqueiro

Nós somos o veneno em seu sistema

Nós somos o futuro, você é futuro

Deus salve a rainha

Nós queremos dizer isso, cara

Nós amamos nossa rainha

Deus salve

Deus salve a rainha

Nós queremos dizer isso, cara

Não há futuro

Nos sonhos da Inglaterra

Sem futuro, sem futuro

Sem futuro para você

Sem futuro, sem futuro

Sem futuro para mim 
Sem futuro, sem futuro

Sem futuro para você

Sem futuro, sem futuro

Sem futuro para você

Sem futuro, sem futuro para você

As duas canções possuem o mesmo objetivo: contestar o sistema político vigente em determinada nação. Se é certo que a cenografia, parte constitutiva de cada um dos discursos é flagrantemente distinta, e isso importa para a construção do sentido, bem como o estatuto do enunciador e de destinatário também distinto nesse caso, é inegável que o tom do que se diz importa da mesma forma para a construção do discurso enquanto todo de significação.

Da dêixis enunciativa e do estatuto do enunciador e de destinatário trataremos nos itens subseqüentes, por hora fiquemos com a noção de modo de enunciação, de vOZ no discurso, do delineamento do sujeito enquanto ser linguajeiro.

Embora seja difícil, faz-se necessário abstrair da figura ontológica dos compositores dessas canções, bem como da composição musical enquanto texto sincrético para fins de semiótica, eis que opera concomitante em planos de significação diversos, uma que trata do ritmo e da harmonia e outra que trata da letra da canção, enquanto manifestação textual.

Ficamos com a manifestação textual, com a letra da canção, até mesmo porque nosso texto central não é sincrético, portanto impertinente uma análise aprofundada nesse campo da semiótica amplamente estudado por outros pesquisadores que têm algo efetivo a oferecer nesse sentido.

Claro que ouvindo as canções acima fica bem clara a distinção da forma de dizer. De um lado Chico, com toda sua fineza e intelectualidade, voz de seda e belas harmonias, de outro Johnny Rotten, maltrapilho e desajustado, berros desafinados e caos sonoro. Assistindo-se a um vídeo clipe então não há como tudo ficar mais claro. 
As pistas para a apreensão do ethos devem erigir do próprio enunciado e não por uma perspectiva sociológica ou de perfil. E o tom do dito pode ser percebido pelo modo de encadeamento das canções.

Na canção de Chico nota-se uma preocupação com a criação de versos rimados e metrificados em regra, do uso de linguagem culta, de ironias inteligentes e demais figuras de linguagem em abundância e uma fala que denota competência para vencer o regime que afronta.

Já na canção dos Sex Pistols o que se observa é uma letra sem preocupações poéticas, o uso de gírias (moron, Hbomb), de ironia agressiva e metáforas risíveis e eventuais e uma fala que denota impotência ante o regime que afronta.

Por meio do modo de enunciação (mas não só), determina-se um ethos de Chico e um dos Sex Pistols. A essa altura, as referências ontológicas servem para confirmar o que se pode apreender pela sondagem discursiva do texto. É essa a intenção da análise do discurso que vimos desenvolvendo.

Esse é apenas um exemplo dentre muitos que serve para aclarar que se não é verdade que o texto escrito emudece a voz da enunciação, devem-se buscar no enunciado do discurso traços que permitam determinar o tom do que é dito.

Segundo Meschonni ${ }^{88}$, a oralidade não é o falado, mas

“o primado do ritmo e da prosódia na semântica, em certos modos de significar, escritos ou falados. A integração do discurso no corpo e na voz no discurso. Uma semântica da significação generalizada, contínua no descontínuo das unidades discretas, ao qual se limita a semântica do signo."

\footnotetext{
${ }^{88}$ In MAINGUENEAU, Dominique. Gênese dos discursos. Cit. p-95.
} 
Em suma, se por meio de uma abordagem meramente lingüística não se faz possível notar a tom do dito, analisando o enunciado por meio de uma abordagem discursiva torna-se possível determinar o modo de existência de determinado sujeito no mundo, seu ethos, sua corporalidade para além do texto, o que permite também a observação de um gênero de discurso.

A partir da análise das tiras de "Garfield" publicadas no jornal Folha de São Paulo, Norma Discini desenvolve exemplar análise do ethos em sua obra "O estilo nos textos ${ }^{89}$. Nessa interessante e reveladora análise, a autora trata em profundidade do que se entende por ethos e seu papel na criação de determinada gênero, informando que:

“É justamente para a construção desse corpo que contribui o modo como a enunciação se referencializa numa totalidade de discursos. Referimonos, lembremos, à instância de uma totalidade, “que é responsável pelo conjunto de avaliações e, portanto, um eu”, retomando palavras de Fiorin (1996:65). Do modo recorrente de referencialização, depreende-se um conjunto de esquemas, que não pode ser aleatório, nem tampouco decorrente de escolhas soberanas do indivíduo. O eu referencializado no enunciado de uma totalidade representa convocações enunciativas que são sociais, históricas e culturais.”

De volta ao discurso jurídico, quando aplicadas essas noções à análise das codificações civis nota-se, mais uma vez a princípio, uma similaridade de dizer o dito em ambas as codificações, própria do texto de lei, que é de onde partimos.

Vale destacar que as leis são redigidas pelo legislador, figura hipotética que se quer imparcial e desapaixonado com o fim de elaborar leis genéricas e abstratas. $\mathrm{O}$ legislador pode ser apenas uma ou muitas vozes partilhadas e o resultado que daí se obtém só pode ser diverso.

${ }^{89}$ DISCINI, Norma. O estilo nos textos. Contexto. São Paulo. 2003. 
Para a caracterização do modo de enunciação, como bem adverte Discini, é necessário a reiteração das mesmas referencializações textuais o que, de certa forma, vai educando o leitor que toma contato recorrente com o texto e que dele espera justamente a recorrência de referências.

A publicação de uma lei é revestida de diversas formalidades, em especial as codificações. Além de serem redigidas pelo Poder Legislativo, contam com a colaboração para sua confecção de membros do Poder Judiciário e são sancionadas e colocadas em vigência por ato do Presidente da República, representante maior do Poder Executivo.

Em razão de seu caráter deôntico, que impõem um dever-ser/dever-fazer para os indivíduos sob pena de sanção e a utilização de linguagem técnica e vernacular, geralmente de difícil compreensão para os que não atuam na área jurídica, a norma jurídica opera no destinador um misto de temor e obediência compulsória, criando-se efeito de sujeito que se impõem pelo dito, que não admite contestação e considerações evasivas.

Se o legislador determinou que "A direção da sociedade conjugal será exercida, em colaboração, pelo marido e pela mulher, sempre no interesse do casal e dos filhos." (art. 1.567 do Código Civil) é assim que devem agir os indivíduos, sob as penas da lei.

O que há aqui é uma relação de subordinação entre aquele que diz e aquele que recebe a ordem. Apagando-se as marcas da enunciação do enunciado e com um tom sempre imperativo, a norma jurídica cria efeito de distanciamento entre destinador e destinatário, sempre necessária nesses tipos de relação.

É a figura do Estado Soberano que se cria, representada nos governos presidencialistas (como é o caso do Brasil) pela figura do Presidente da República. No texto pode-se notar efeito de respeito à ordem, tal como o filho obedece às ordens dos pais ou o empregado às ordens do patrão, tudo sob pena de sanção. 
É esse, portanto, o tom do discurso que se observa tanto no Código Civil de 1916 como no Código Civil de 2002, no entanto, com algumas diferenças. Explica-se: O Código revogado, como já se comentou ao se tratar do modo de coesão, pretendo-se estabelecer como um conjunto de normas exaustivas que encerram todas as questões que permeiam o casamento, quer ser a única voz a determinar os anseios sociais, o modo de agir e conduzir as relações pelos sujeitos, não admitindo situações que transbordem suas previsões.

Já o Código em vigência, recorre a um discurso mais moderado, com menos inserções de texto de lei e que, não raro, estão abertos para novas situações, tal como o fez ao permitir, ao lado do casamento civil, o reconhecimento da união estável que, conforme já esclarecido nos capítulos anteriores, não é propriamente uma criação do legislador, mas o reconhecimento de algo há muito existente na sociedade, o já referido casamento de fato, que se tornou concubinato puro sob a égide da codificação civil anterior.

Eis mais uma vez a perfeita consonância do Código Civil de 1916 com o discurso jansenista, eis que alheio à vontade dos indivíduos que não poderiam fazer nada mais do que adequar suas ações ao disposto em lei para receberem sanção positiva, ao passo que o Código Civil de 2002, ao admitir uma forma de união que não é casamento civil, mas que gera efeitos semelhantes, está a admitir outros caminhos para a união entre homem e mulher, mais afeitos ao discurso humanista devoto, portanto.

Uma análise mais extensa das codificações faz a todo tempo se perceber essa diferença de tom por meio das opções do legislador por termos mais vagos e abrangentes na nova codificação que acaba por delegar ao interlocutor, geralmente os juízes e advogados, o dever de interpretar a lei à luz do caso concreto, provavelmente com a intenção de aumentar a sobrevida da codificação, sempre adaptável aos fatos concretos que vão se transformando e evoluindo (ou retrocedendo, conforme o caso).

Já a codificação de 1916 busca um enfeixamento perfeito de normas (perfeito apenas na intenção, por certo), dando pouca margem ao intérprete para adequar a lei ao caso concreto, produto direto do modo de enunciação específico tomado pelo legislador, preocupado com o cometimento de arbítrios por parte dos intérpretes em virtude da 
vagueza do texto legal, o que não poderia admitir e que restará mais claro com a análise do tópico a seguir.

De qualquer modo, como se disse ao longo do estudo do modo de enunciação, a recorrência de referencializações vão educando o leitor atento dos textos, sendo certo que a nova codificação que começa a ser colocada em prática pelos intérpretes carece da incorporação desses anseios por parte de seus interlocutores, sob pena de tornar-se inócua toda a pretensa evolução legislativa, que não se operará se não houver mudança no modo de interação com o texto legal por parte daqueles.

\subsection{Dêixis enunciativa}

De acordo com Dominique Maingueneau em sua obra "Novas Tendências em Análise do Discurso", a dêixis enunciativa manifesta-se no universo de sentido que uma formação discursiva constrói através de sua enunciação.

O Código Civil de 1916 entrou em vigor em $01^{\circ}$ de janeiro de 1917 , sendo que a previsão de sua edição já se encontrava na Constituição Federal de 1824. Ocorre que a incumbência de elaborar o Código foi passada para diversos juristas, com destaque para Teixeira de Freitas, que elaborou a Consolidação das Leis Civis, que acabou não sendo aproveitado no Brasil em razão da demora em sua conclusão, mas que serviu de inspiração para o Código Civil da Argentina de Vélez Sarsfield. Somente em 1899 Clóvis Bevilaqua assumiu o encargo e entregou em 1900 o Código Civil para o governo republicano, entrando em vigor após longos anos de debates nas casas legislativas onde sofreu alterações, na maior parte de ordem lexical.

O Código Civil de 1916 adveio de um trabalho de cátedra de Clóvis Bevilaqua debruçado sobre o Código de Napoleão, razão pela qual os artigos de lei são comandos fechados, que não dão grande margem ao operador do direito para tecer interpretações, o que era justamente a vontade de Napoleão, que com isso procurava evitar que o magistrado se valesse da discricionariedade para sempre favorecer ao status quo. 
O Código Civil de 2002, por sua vez, surgiu da natural necessidade de atualizar as prescrições legais contidas no Código anterior, que já havia sido modificado em várias partes em razão do surgimento, dentre outras leis, do Estatuto da Mulher, da Lei do Divórcio e principalmente da Constituição Federal de 1988.

Tendo como mentor o jurista Miguel Reale, o encargo de elaborar o projeto de lei foi partilhado com notáveis do direito especializados em determinadas áreas de conhecimento que compõem o Direito Civil, destacando-se a atuação do Professor Agostinho de Arruda Alvim, Clóvis de Couto e Silva e Torquatro Castro.

O sentido social é filosofia marcante no novo estatuto, em reação ao individualismo euforizado no velho código. Em diversas oportunidades, Reale afirma que a linguagem dos artigos de lei por vezes é simplificada para seu melhor entendimento, o que denomina de operosidade das normas, sendo que se tratam de disposições abertas em oposição às normas fechadas do velho código, dando aos magistrados maior margem de discricionariedade ao aplicar a lei ao caso concreto. Junto com a sociabiliadade e a operosidade, a eticidade também é um dos princípios basilares da nova codificação.

Maingueneau ressalta que

"se existe dêixis discursiva é porque uma formação discursiva não enuncia a partir de um sujeito, de uma conjuntura histórica e de um espaço objetivamente determinados do exterior, mas por atribuir-se a cena que sua enunciação ao mesmo tempo produz e pressupõe para se legitimar $" 90$

Assim, pode-se dizer que o Código Civil de 1916 é um trabalho individual (voz única) que resulta em um sistema de leis fechadas e pautadas no individualismo, ao passo que o Código Civil de 2002 é composto por uma voz compartilhada que resulta em um sistema de leis abertas e pautadas no sentido social do direito.

\footnotetext{
${ }^{90}$ MAINGUENEAU, Dominique. Gênese dos discursos. Cit. p - 42.
} 
De um trabalho individual, de fato, o que se obtém é um discurso autoritário que busca mais o reconhecimento da perfeição textual do que a qualidade do que se comunica, uma vez que não há propostas alheias para obtemperar o pensamento individual, por vezes equívoco.

Essa concepção de codificação aproxima-a do que Maingueneau observou no discurso jansenista, que cunhava sua dêixis na Igreja Primitiva, distante da realidade da França do século XVII.

Daí advém um trabalho distante da realidade social que a codificação deveria regrar, uma vez que um trabalho de cátedra baseado nas idéias que predominavam na França do século XVIII só poderia restar demasiado afastada da sociedade brasileira dos fins do século XIX.

Não é bem a distância temporal que torna a codificação anterior incongruente com os anseios da sociedade de seu tempo - até mesmo porque o Código de Napoleão, com pontuais modificações, continua em plena vigência na França -, mas a distância da realidade social que vivia a França naquela época e a do Brasil Império que recebeu o Código de 1916.

Muito embora boa parte dos conceitos e dogmas jurídicos advenha de épocas até mesmo mais remotas do que a França pós-revolução, sendo ainda hoje forte a influência do Direito Romano em todos os ramos do direito civil, não há como se negar que a norma jurídica deve se adaptar à realidade social, sob pena de se torna letra morta, eis porque incompreensível quando confrontada com a realidade social.

Mais uma comprovação da inspiração lógico-formal do Código Civil de 1916, mais preocupado em fazer ciência, em criar um conjunto de normas perfeito e acabado do que em dar ao povo aquilo que precisa para viver dignamente.

Já o Código Civil de 2002, conforme se noticia, teve a preocupação de fundar-se em voz partilhada, como já se disse, dividindo seu trabalho de produção por meio de notáveis do meio jurídico e, mais do que isso, com representantes de regiões diferentes do Brasil, para não ser acusado de bairrista e com o evidente intuito de aproximar a 
legislação civil da realidade social, não obstante as acusações de ser inspirado no Código italiano originado no período facista, especialmente pelas íntimas relações do então jovem Miguel Reale com o Partido Integralista do Brasil.

De qualquer modo, não sendo a intenção deste trabalho desferir ácidas críticas a quaisquer autores ou linhas de pensamento, em respeito até mesmo à liberdade de expressão dos indivíduos e o entusiasmo pela pluralidade de pensamentos, que torna mais rica a análise discursiva aqui desenvolvida, fato é que o Código de 2002 mantém consonância com os traços característicos do humanismo devoto, de acordo com as lições de Maingueneau, que admite as opiniões do povo de seu tempo não apenas diretamente a palavra de Deus, as lições de Santo Agostinho.

\section{5 estatuto do enunciador e do destinatário}

Prosseguindo, agora se faz necessário determinar o estatuto que o sujeito enunciador deve assumir e o estatuto que atribui aos seus presumíveis destinatários para se determinar o que confere a cada um a legitimidade para se colocar nesses respectivos lugares do processo enunciativo.

Muito embora os códigos só entrem em vigor após debates nas Casas Legislativas, deve se considerar enunciador de um código seu(s) idealizador(es), uma vez que a atuação dos senadores e deputados federais é apenas superficial, vale dizer, não mudam a orientação dada pelo idealizador, apenas operam alterações com vistas a adequar o trabalho do jurista aos interesses da maioria da população.

Faz parte da tradição jurídica delegar a elaboração das grandes codificações a indivíduos dotados de um notável saber jurídico, ao contrário do que ocorre com as demais espécies de leis, as quais não estão vinculadas a um determinado idealizador.

Talvez isso ocorra em razão das codificações serem corpos legais cuja existência norteia todo um ramo do direito, traçando os princípios gerais que deverão ser obedecidos pelas demais leis e que deve contar com uma visão privilegiada do direito, capaz de criar leis que não percam sua atualidade a curto e médio prazo, em razão de avanços das mais diversas ordens. 
Foi assim que a tarefa de elaborar a Consolidação das Leis Civis do Brasil foi entregue ao renomado jurista Teixeira de Freitas; Orlando Gomes em meados da década passada elaborou ante-projeto de um Código das Obrigações, com o fim de uniformizar o direito privado e revogar a parte geral do Código Civil então em vigor; Nelson Hungria foi convidado para elaborar o Código Penal. Esses são apenas alguns exemplos de uma tradição que se repete freqüentemente.

Dessa forma, pode-se a princípio colocar como enunciador do Código Civil de 1916 seu idealizador, Clóvis Bevilaqua e como enunciador do Código Civil de 2002 Miguel Reale, organizador dos trabalhos de criação do novo estatuto civil, possuindo, cada um a seu tempo, papel de destaque no campo do direito.

Clóvis Bevilaqua formou-se em direito na Faculdade do Recife, tornando-se juiz um ano após a conclusão de seu curso, foi professor de filosofia da Faculdade de Direito do Recife e autor de diversas obras que até hoje podem ser consultadas com proveito por estudiosos do direito.

Clóvis também foi o fundador da cadeira número quatorze da Academia Brasileira de Letras, que tem como patrono Franklyn Távora, instituição da qual se desligou, dizem, em razão daquela entidade não ter aceitado o pedido de inscrição que fez sua esposa, Amélia de Freitas Bevilaqua, para disputar uma das cadeiras da Academia sob a alegação de que as mulheres não poderiam ser acadêmicas.

O Código de 1916 falava para uma população essencialmente rural, ainda sem tradição jurídica e praticamente ignorante do que se passava no resto do mundo e do território nacional, cultivando hábitos retrógrados, olhando para o século XIX, que ainda era a referência cultural do povo brasileiro do início do século passado.

Miguel Reale é advogado, jurista, professor, filósofo, ensaísta, poeta e memoralista, é natural de São Paulo e formou-se na Faculdade do Largo São Francisco. Em 1975 foi eleito para a mesma cadeira que fora de Clóvis Bevilaqua na Academia Brasileira de Letras, na sucessão de Fernando de Azevedo.Vale destacar também que Miguel Reale foi reitor da Universidade de São Paulo entre 1949 e 1950 e de 1969 a 
1973, quando implantou a ampla reforma universitária com a substituição das cátedras pelos departamentos. Para a efetiva implementação e urbanização do campus da USP, construiu cerca de $250.000 \mathrm{~m} 2$ de edifícios destinados ao ensino, à pesquisa, ao esporte e lazer.

A bibliografia fundamental de Reale compreende obras de filosofia, filosofia jurídica, teoria geral do direito, teoria geral do estado, além de monografias em quase todos os ramos do direito público e privado, com destaque para a criação da teoria tridimensional do direito, que inspirou muitas das alterações encontradas no novo Código Civil.

O Código Civil de 2002 fala para uma população urbana, globalizada, que usufrui de fácil acesso aos meios de comunicação e que por essa razão sabe melhor o que se passa no Brasil e no mundo, seus direitos e deveres, sempre de olho nas modernidades, na agilidade, olhando para adiante do novo século.

Nada mais natural, portanto, que a codificação civil em vigor recepcionar o instituto da união estável e operar adequações no casamento civil para conformar-lhe com as mudanças sociais que se operaram ao longo do século em que vigeu o Código de 1916.

Notável é a diferença entre as duas codificações no que se refere ao regime de bens entre os cônjuges, por exemplo. Por um lado, temos o Código de 1916 que adotava o regime da comunhão universal como o regime legal e conferia expressiva importância ao regime dotal.

De acordo com Maria Helena DINIZ ${ }^{91}$ :

"Pode-se conceituar como regime dotal aquele em que um conjunto de bens, designado dote, é transferido pela mulher, ou alguém por ela, ao marido, para que este, dos frutos e rendimentos desse patrimônio, retire o

${ }^{91}$ DINIZ, M.H. (1997). Curso de direito civil brasileiro. São Paulo. Saraiva. P - 158. 
que for necessário para fazer frente aos encargos da vida conjugal, sob a condição de devolve-lo ao término da sociedade conjugal.”

O legislador falava, portanto, para uma sociedade que entendia o casamento quase como uma delegação da obrigação de sustentar a mulher por parte de seu pai ao seu cônjuge que, recebendo o dote recebia também a incumbência de administrar o patrimônio adquirido para manter o padrão de vida da mulher.

Essa prática tornou-se com tempo cada vez menos usual, até mesmo porque a mulher deixou de ser meramente a responsável pelas tarefas domésticas e passou a desempenhar atividades econômicas, adquirindo patrimônio próprio e, com isso, autonomia de vida em relação aos pais e marido.

Nota-se que o regime dotal centra no patrimônio a importância do casamento e o torna o elo mais forte desta relação, uma vez que sua manutenção fica na dependência da permanência da sociedade conjugal, uma vez que nos termos do art. 300 do Código Civil de 1916, “O dote deve ser restituído pelo marido à mulher, ou a seus herdeiros, dentro no mês que se seguir à dissolução da sociedade conjugal, se não puder ser imediatamente (art. 178, $\S 9^{\circ}, I, c$, e II)"

Não havendo mais espaço na sociedade para um regime com esses contornos, com o passar dos tempos foi caindo em desuso até que, socialmente, foi banido como regime de bens das sociedades conjugais, o que foi observado pelo legislador do Código que 2002, que o aboliu e criou um novo regime, que denominou de regime de participação final nos aquestos, assim definido pela já mencionada autora Maria Helena DINIZ ${ }^{92}$ :

“Regime matrimonial de bens em que há formação de massas de bens particulares incomunicáveis durante a vigência do casamento, mas que se tornam comuns no momento da dissolução da sociedade conjugal (CC, art. 1.571). Assim sendo, na constância do matrimônio, os cônjuges têm a

\footnotetext{
${ }^{92}$ DINIZ, Maria Helena. Código Civil Anotado. São Paulo. Saraiva. P-111.
} 
expectativa de direito e à meação, pois cada um é credor da metade do que o outro adquiriu, onerosamente, durante a vida conjugal, havendo dissolução do casamento."

Note-se que aqui os enunciatários são homens e mulheres que vivem em situação de independência patrimonial, não há prevalência de um sobre o outro, tornado-se o aspecto econômico independente do aspecto afetivo, uma vez que havendo a dissolução da sociedade conjugal não há perda de dote ou qualquer conseqüência do gênero, sendo o patrimônio dividido de acordo com a participação efetiva de cada cônjuge em sua conquista.

\section{6 tema}

Tratar do tema de determinado discurso tal como prelecionado por Maingueneau importa em determinar seu sistema de restrições semânticas ou, em outras palavras, não é apenas aquilo que o discurso trata considerado o tema em si mesmo, mas a maneira como ele se constrói a partir de restrições semânticas operadas em níveis mais profundos.

Seguindo por essa linha de raciocínio, temos que nas codificações civis tratar do tema não significa explicar todos os conceitos de direito civil, em especial de direito de família e do casamento e da união estável, mas de que maneira o tema casamento, o tema união estável e seu tratamento discursivo encontram respaldo em um sistema de restrições semânticas mais essenciais.

Ora, não há dúvida de que, aparentemente, tanto o Código de 1916 quanto o Código de 2002 tratam do tema/casamento/, guardando efetiva semelhança em superfície.

No entanto, sob a ótica das restrições semânticas de cada texto, o que se observa é um tanto diverso, uma vez que aqui sua oposição é global, de um sistema de restrições 
a outro ${ }^{93}$ e, sob essa perspectiva afloram todas as distinções semânticas apontadas nos demais tópicos dessa análise.

Por se tratarem de codificações civis, não poderiam deixar de lado certos temas que importam para a vida dos cidadãos, eis que essa é a razão de ser de referidas codificações.

É por isso que buscam regrar a vida dos indivíduos desde sua concepção, já conferindo direitos ao nascituro, até a sucessão de seus bens em razão de morte e tudo o que os homens realizam entre a vida e a morte, tais como assinar contratos, adquirir bens, constituir família.

Isso posto, é considerável também a possibilidade do legislador de optar por prescrever ou não determinado tema e de maneira mais conforme ao sistema de restrições semânticas do texto. É o que MAINGUENEAU denomina temas impostos e não impostos ${ }^{94}$ :

"Por definição, os temas que não são impostos pelo campo discursivo podem estar ausentes de um discurso, mas aqueles que são impostos podem estar presentes de maneiras muito variadas: um tema imposto que é dificilmente compatível com o sistema de restrições globais será integrado, mas marginalmente, enquanto que um tema imposto fortemente ligado a esse sistema será hipertrofiado.”

O Código Civil de 1916 confere grande importância ao que denomina "direitos e deveres do homem" e "direitos e deveres da mulher", porque em consonância com seu caráter de /individualidade/, da mesma forma que confere importância ao regime dotal, que atribui ao aspecto patrimonial grande importância para a continuação da sociedade conjugal.

\footnotetext{
${ }^{93}$ MAINGUENEAU, Dominique. Gênese dos discursos. Cit. p - 86 .

${ }^{94}$ MAINGUENEAU, Dominique. Gênese dos discursos. Cit. p - 87.
} 
É interessante notar que concede trinta e três artigos de lei para o regime dotal e apenas dois artigos de lei para o regime da separação total de bens. Eis um tratamento marginal de referido instituto.

Já no Código de 2002 é notável a maior liberdade que confere para a estipulação do regime de bens do casal, preocupando-se mais com disposições de ordem geral do que com os regimes em específico, exceção feita ao regime de participação final nos aquestos, o que pode ser atribuído à novidade do instituto, que acaba cercado de maiores cautelas para evitar exacerbados desvios interpretativos.

Isso guarda consonância com o traço semântico característico do discurso do Código de 2002, uma vez que eufemiza a importância do patrimônio para a manutenção da sociedade conjugal, pelo temor de perda patrimonial que, no entanto, ainda ocorre e que por isso não pode deixar de ser regrado.

Também guarda consonância com a semântica global do texto civil de 2002 excluir o tema "direitos e deveres do marido" e "direitos e deveres da mulher" e criar obrigações comuns para os cônjuges, o que confere maior relevo ao traço semântico de /união/.

Também não se pode deixar de notar que, embora recepcionado pelo novo Código Civil, a união estável é tratada de maneira marginal, ao passo que todo o regramento jurídico é conferido para o casamento civil em todos os seus aspectos, fazendo mera menção retroativa ao instituto da união estável, conferindo-lhe relevo de juridicidade mas não deixando de tratá-lo de modo marginal.

Isso porque o sistema de restrições semânticas do texto indicava a necessidade de recepção do instituto da união estável, enquanto codificação civil com o desejo de manter estreita relação com efetiva vida em sociedade, em vista de seu caráter de /sociabilidade/, o que de fato faz, aparentemente tratando-o como tema imposto relegado a um mero apêndice do capítulo que trata do direito de família. 


\section{7 vocabulário}

Tratar do vocabulário em sede de semântica global não é o mesmo que abordar o léxico por meio de traços semânticos de seus signos, mas justamente explicar como são carregadas mencionadas cargas semânticas a partir do sistema de restrições do discurso considerado como um todo.

Ao substituir os termos "direitos e deveres do homem" e "diretos e deveres da mulher" por "deveres de ambos os cônjuges" é euforizado o termo "cônjuge" e disforizado os termos "marido" e "mulher" enquanto signos com traços semânticos de distinção dentro dos limites da previsão legal.

Se é certo que há diferenças das mais diversas ordens entre homem e mulher, quis o legislador anulá-las quando tratadas as pessoas sob a perspectiva legal, uma vez que a codificação civil de 2002 não privilegia os traços de /individualidade/ do código anterior, mas sim de /união/, de igualdade.

Ao inserir no léxico jurídico o termo /união estável/ procura cumprir sua intenção de aproximar-se da realidade social, afirmar seu traço de /sociabilidade/ e, ao mesmo tempo, reconhecer que é da união em si das pessoas que se ocupa o código e não meramente da maneira como essa união é contraída e confere ainda maior segurança ao instituto então criado tratando de distingui-lo expressamente do que se entende por concubinato (art. 1.727 do Código Civil).

Já o Código de 1916, ao inserir em seu léxico apenas o signo casamento civil nega existência jurídica quer à união estável quer ao concubinato (concubinato puro e impuro, respectivamente, naquele tempo). Mais do que isso ao criar a figura dos /filhos legítimos/ em oposição aos /filhos ilegítimos/, concebidos, respectivamente, dentro e fora da sociedade conjugal, deixa bem clara a recepção negativa que faz das uniões conjugais distintas do casamento civil. 
Além disso, ao fazer incluir o signo /regime dotal/ privilegia o aspecto patrimonial do casamento, tornando-se condição para a manutenção de determinada posição social, uma vez que o mesmo é perdido na hipótese de dissolução da sociedade conjugal.

Esses são apenas alguns aspectos do vocabulário que se convencionou levar em consideração nesta análise e que parecem reiterar as impressões extraídas dos demais estratos que conferem sentido ao texto, sob uma abordagem de análise do discurso.

Não sendo pretensão deste trabalho esgotar a análise de todo o conteúdo das codificações civis brasileiras, até mesmo porque suas dimensões são estratosféricas, o que acabaria por nos levar a perder o fio da análise pretendida dentro de um sem número de definições e concepções dos mais diversos institutos jurídicos, conferindo ao trabalho mais revestimento jurídico do que de análise do discurso propriamente dita, o fato é que se as distinções entre os textos operam-se em bloco, conforme demonstrado, futuras análises de outros extratos do texto selecionado devem chegar a resultados semelhantes, eis que o sentido está no todo e em cada parte que compõe o todo.

\section{Breves notícias jurídicas sobre a união estável}

Tratada a questão sob perspectiva social, cabe agora expor como o discurso jurídico regra o casamento e o concubinato, incluindo aí o instituto da união estável. Servirá de base a essa análise, sobretudo, as lições do renomado jurista Álvaro Villaça Azevedo, a uma porque preocupa-se sobremaneira com essa questão, ou porque foi o responsável por coordenar os trabalhos para as alterações previstas na atual codificação civil no que diz respeito ao direito de família.

Referido autor, ao traçar os condicionantes históricos que importam para a definição de casamento e concubinato, a partir da leitura dos textos da Roma Antiga esclarece que, naquele tempo,

"Realmente, bastava que um homem convivesse com uma mulher, por algum tempo, como se casados, com ou sem celebração religiosa, para que se considerasse sob casamento. Isto, porque, nessa época, o concubinato 
puro, não adulterino nem incestuoso, que é utilizado, hoje, como modo de constituição de família, era o casamento de fato, provado por escritura pública ou por duas testemunhas." 95

Em seguida, critica o autor o revestimento excessivamente formal e jurídico que foi conferido ao casamento, que deveria ser tratado como fato social, tratando a legislação de regulá-lo somente no tocante a seus efeitos, para impedir violações de direitos. Não foi assim que a união conjugal foi tratada pela codificação civil de 1916.

O Código Civil Brasileiro de 1916, em consonância com o previsto no Decreto Lei $\mathrm{n}^{\mathrm{o}}$ 181, de 24 de janeiro de 1890 elegeu o casamento civil como única maneira legal de união entre homem e mulher, relegando o que até então era conhecido como casamento de fato como relação concubinária, ainda que a união fosse celebrada diante de determinada autoridade religiosa.

Não havia, a essa altura, distinção relevante entre as diversas formas de concubinato. Ainda que se reconhecesse, como de fato há, nítida diferença do que se entende por concubinato impuro (adulterino, incestuoso, desleal) e concubinato puro ${ }^{96}$.

A ausência de distinção de trato jurídico de uniões entre pessoas de cunho manifestamente conflitantes sempre foi fonte de grandes injustiças e preconceitos, tratando como transgressores da lei tanto aqueles que se uniam em evidente desacordo com a moralidade média da população quanto aqueles que tinham a intenção de constituir o que, antes da entrada de referidas leis em vigência, eram reconhecidos como casamento de fato (como o era no Brasil na época em que vigiam as Ordenações do Império).

95 AZEVEDO, Álvaro Villaça in "Revista do Advogado $n^{\circ}$ 58". Publicação da AASP. Março/2000. P - 15.

96 AZEVEDO, Álvaro Villaça in "Revista do Advogado n ${ }^{\circ} 58$ ". Cit. P - 16): "É puro o concubinato, quando se constitui a família de fato, sem qualquer detrimento da família legítima ou de outra família de fato (este poderá rotular-se, também de concubinato leal). Assim ocorre, por exemplo, quando coabitam solteiros, viúvos e separados judicialmente, sob essa forma de constituição familiar." 
Fosse qual fosse a relação concubinária, a lei não conferia qualquer tipo de proteção para os convivas, o que acabava por deixar sem proteção estatal aqueles indivíduos que se viam espoliados em razão de desacordos nessas relações, notadamente nas relações concubinárias puras, o que fere o senso de justiça do homem médio.

Além disso, os filhos havidos dessas relações eram considerados ilegítimos, em oposição à filiação legítima, fruto do casamento civil. Tanto a companheira como os filhos ilegítimos eram preteridos em casos de sucessão patrimonial em razão de morte do outro, notadamente quando, antes de iniciar o concubinato puro havia constituído família anterior por meio de casamento civil, que conferia ao cônjuge supérsiste direitos de meação, legados e herança, bem como eram considerados sucessores legítimos sua prole.

Tais fatos sempre foram comuns, notadamente quando no Brasil ainda vigorava a figura do desquite como meio de dissolução da sociedade conjugal, o que impedia aos desquitados a possibilidade de contraírem novo casamento civil.

Mesmo depois, com o advento da Lei do Divórcio, que passou a permitir novo casamento por aquele que se tornara divorciado, na prática muitas pessoas se uniam sem as formalidades legais, mas como a nítida intenção de constituir família.

Com isso, diversas contendas foram levadas aos Tribunais pátrios, que convivia com a árdua tarefa de superar preconceitos e empecilhos legislativos para não deixar à margem da lei a espoliação de direitos daqueles que agiam de boa-fé e tinham por razoável o direito de pleitear a proteção legal, notadamente no que se referia a questões patrimoniais e de prestação de alimentos.

Aqui já ganhava relevo o papel criador e inovador da jurisprudência para o ordenamento jurídico. A jurisprudência é corriqueiramente definida como o conjunto de decisões reiteradas a cerca de um tema pelos Tribunais de determinada nação. É no Judiciário que a lei geral e abstrata é tornada norma concreta e aplicada ao caso específico que lhe é submetido. 
Como o juiz só se manifesta quando provocado por meio de demandas judiciais (princípio da inércia judicial), a jurisprudência pode ser considerada como autêntica produção social que provoca o judiciário a adequar as distorções legais.

Ora, não tendo contraído casamento civil e tendo preteridos seus direitos, um sem número de jurisdicionados passaram a propor demandas judiciais para verem reconhecidos o direito de partilha de bens, prestação de alimentos, etc., na hipótese de dissolução das chamadas relações concubinárias.

Chamado a resolver tais contendas, os membros do Poder Judiciário, caso a caso, passaram a acolher os pleitos que lhes eram encaminhados, culminando na criação de um conjunto de decisões judiciais que iam concedendo direitos patrimoniais aos conviventes em relações concubinárias.

A produção jurisprudencial ganha maior relevo quanto mais alta a Corte que profere a decisão. Assim, as decisões dos Tribunais de Justiça estaduais no sentido de concessão de direitos aos concubinos tem sua importância que, no entanto, é inferior à importância dada às decisões do Superior Tribunal de Justiça e do Supremo Tribunal de Justiça, o Pretório Excelso.

Os Tribunais superiores, na medida em que reiteram suas decisões, tendem a torná-las súmulas, ou seja, um preceito jurisprudencial que goza de maior estabilidade. Explica-se:

A construção jurisprudencial, por se originar de conflitos de interesses, pode, por vezes, pender por acatar o pleito de uma ou outra parte partícipe da demanda. No caso em análise, muitas foram as decisões que deixavam de reconhecer direitos patrimoniais aos concubinos, principalmente aquelas proferidas por magistrados com tendência legalista, da mesma forma que outros, de tendência mais humanitária, conferiam-lhes direitos.

À medida que essas decisões passam a ser proferidas mais constantemente, favorecendo uma das partes da relação processual, a jurisprudência vai se consolidando como majoritária e, ato contínuo, em decisão plenária, os Ministros dos Tribunais 
Superiores tendem a torná-las súmulas, que são a consolidação do entendimento majoritário do órgão superior que tratará aquele tema em última instância.

As súmulas, embora não vinculem as decisões dos órgãos judiciais inferiores, servem de norteadores das decisões judiciais dessas últimas que, aderindo a elas, contribuem para a cessação prematura e desejada de contendas cuja decisão final já é estabelecida na última esfera.

Foi assim que aconteceu com a seguinte decisão no que se refere a direitos patrimoniais frutos de relações concubinárias, com a edição da Súmula 380 do STF, in verbis:

\section{SÚMULA 380}

Comprovada a existência de sociedade de fato entre os concubinos, é cabível a sua dissolução judicial, com a partilha do patrimônio adquirido pelo esforço comum.

Eis aqui uma conquista de direitos por parte dos concubinos por meio de decisões jurisprudenciais. No entanto, tal Súmula não dá satisfatoriamente a distinção legal do que se entende por concubinato puro e concubinato impuro, uma vez que, ao tratar de "concubinos", da mesma forma que o texto legal não difere ambos pela intenção de constituir família, da mesma forma não o fez o Pretório Excelso.

Como se pode notar da leitura de referida súmula, o reconhecimento judicial da partilha de bens só se dava com a comprovação de aquisição de patrimônio pelo esforço comum. Não há relevância a intenção de se constituir família ou não, bastava a comprovação da existência de uma sociedade de fato, de uma mera relação negocial.

Isso implicava no não reconhecimento de direito à partilha de patrimônio por parte da concubina que havia apenas cuidado do lar ao longo da relação, sem ter efetivamente contribuído a título oneroso para a aquisição do patrimônio. 
Mais uma vez caminhou a jurisprudência no sentido de obtemperar a dicção da súmula em apreço, passando a admitir como colaboração relevante a participação na manutenção do lar por parte da concubina, o que conferia evidente tranqüilidade para o concubino realizar atividades econômicas para o sustento da família e aquisição de patrimônio, considerado comum quando adquirido na constância da relação concubinária.

Atualizando algo que foi mencionado quando se buscou distinguir a distinção entre as duas definições do dicionário para concubinato, referido direito só era concedido à concubina que convivia em regime de concubinato puro, o único passível de constituir família.

Pode-se dizer que foi a partir daí que começou a se notar um princípio de distinção, no âmbito jurídico, do que em doutrina se dizia concubinato puro e impuro.Tal distinção tornou-se evidente com a diferenciação de tratamento por parte do judiciário no que se refere à proteção judicial das relações.

Finalmente, com o advento da Constituição Federal de 1988, o concubinato puro passou a ser reconhecido como entidade familiar, que merece a devida proteção do estado, nos termos do art. $226, \S 3^{\circ}$.

Temos aqui a criação de um novo signo dentro do discurso jurídico: /união estável/. De pronto, nota-se a intenção do legislador - abandonando a tradicional distinção entre concubinato puro e impuro e criando um neologismo -, de distinguir claramente uma forma de concubinato da outra: quando há a intenção e a possibilidade de se constituir uma entidade familiar, a relação é tida como união estável; quando não há a possibilidade de se constituir uma entidade familiar, há concubinato.

Distanciando-se os significantes e carregando cada um deles com semas manifestamente distintos procura o legislador operar efeito de distanciamento entre os dois termos, euforizando aquele que caminha para a integração (como dito linhas acima, que nega a transgressão). 
Louvável atitude acabou por sanar um problema que, afora a questão social, era também de ordem semântica: dois significados antagônicos desde as oposições fundamentais tratados como sinônimos.

Uma vez alçada à condição de entidade familiar por parte de nossa Lei Maior, agora com uma definição própria para o que se convencionou denominar/união estável/, coube às leis infra-constitucionais regrarem as questões patrimoniais suscitadas por conta da dissolução de referidas sociedades conjugais.

Conforme já expresso anteriormente, isso se deu com o advento, respectivamente das leis esparsas e ordinárias $n^{\circ}$ s 8.971/94, 9.278/96 e, finalmente, com a edição do novel Código Civil, quando se operou definitivamente a correção do excesso de rigor da codificação anterior que só admitia o casamento civil como de acordo com o ordenamento jurídico, em detrimento do então concubinato puro.

Veja que foi necessário quase um século, muitos debates doutrinários e acadêmicos, a edição de uma nova Constituição e Codificação Civil para que a mudança social ganhasse reflexo no universo jurídico.

Quando se verificou a semântica de referidos termos em dicionários de língua portuguesa, pôde-se também notar que apenas um deles não apresentava a segunda definição de concubinato mais afeita ao que hoje se entende por união estável no direito.

Isso porque o primeiro dicionário visitado foi tirado de site de internet, produzido em data recente, ao contrário do terceiro dicionário, editado nos anos 70 do século passado, que ainda não incorporara referida distinção, o que está a comprovar, mais uma vez, a impregnação da ideologia na linguagem de determinado povo.

Determinar se foi o dicionário jurídico que influenciou na incorporação da nova acepção de concubinato nos dicionários de língua portuguesa ou se os fatos se deram ao revés não é possível se determinar por meio de nosso instrumental teórico, mas o que importa é que comprova que a linguagem é formação social por excelência, nunca estanque, porque sempre determinada por seu uso. 
Vale ressaltar que a Lei de 1994 reconhecia a união estável, para fins sucessórios apenas se a relação perdurasse ao menos por 05 anos, conforme segue:

Art. $1^{\mathrm{o}}$ - A companheira comprovada de um homem solteiro, separado judicialmente, divorciado ou viúvo, que com ele viva há mais de cinco anos, ou dele tenha prole, poderá valer-se do disposto na Lei 5.478, de 25 de julho de 1968, enquanto não constituir nova união e desde que prove a necessidade.

No entanto, ainda não pode ser tida como uma definição exata de união estável, tendendo mais para meros requisitos legais para a obtenção de direitos patrimoniais e alimentares, sendo certo que o Código Civil de 2002, em consonância com a melhor doutrina define união estável da seguinte forma:

Art. 1.723. É reconhecida como entidade familiar a união estável entre o homem e a mulher, configurada na convivência pública, contínua e duradoura e constituída com o objetivo de constituição de família.

Sob esse aspecto, o que se conclui é que a formação de determinada legislação, em especial as codificações, não se opera por obra de um enunciatário específico ou de um discurso considerado individualmente, mas do diálogo permanente entre diversas formações discursivas, tais como o discurso sociológico, antropológico, religioso e filosófico que, por meio da análise doutrinária das leis, cria precedentes jurisprudenciais que, se de fato sedimentados, acabam por determinar, compulsoriamente, a sua recepção pelo ordenamento jurídico, como eco da voz social que faz valer.

Esse raciocínio pode ser expresso no seguinte esquema: 


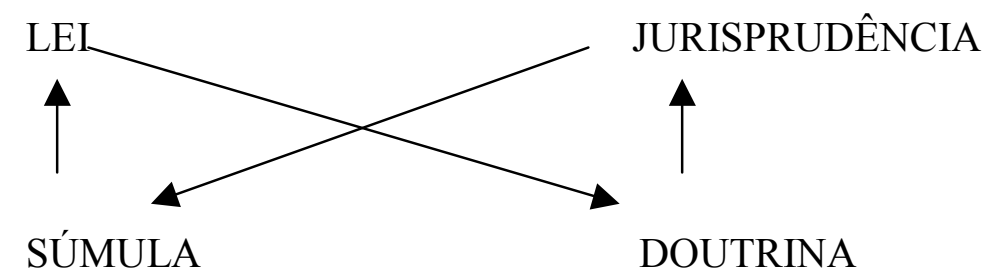

Assim, temos que a lei, interpretada à luz dos doutrinadores do direito, torna-se jurisprudência. A jurisprudência, uma vez sedimentada por decisões reiteradas dos tribunais a respeito de determinado tema, tendem a ser sumuladas e, após certo período de existência, as súmulas tendem a ser recepcionadas pelo ordenamento jurídico por meio de sua recepção por leis.

Pelo que foi exposto até aqui, parece ser bem esse o caminho que levou o instituto da união estável a passar de construção jurisprudencial a situação social sumulada que caminhou para sua recepção pelo ordenamento jurídico, uma vez que a lei não poderia se eximir de regrar tal relação intersubjetiva em sociedade sob pena de perder seu caráter de texto primeiro.

Provavelmente, é assim que as relações homoafetivas encontrarão seu caminho na legislação civil pátria. Primeiro, como já se observa, como construção jurisprudencial. Depois, possivelmente, como prática jurisprudencial sumulada, tornado-se expediente regrado por legislação esparsa e, posteriormente, em um outro possível movimento de transição de codificações, como instituto implementado o solidamente reconhecido pelo ordenamento pátrio. 


\section{CONCLUSÃO}

Com a pesquisa empreendida foi possível revisitar alguns institutos de interesse para a área jurídica, tais como a configuração semântica das normas jurídicas que, embora tenha sido objeto de estudo de uma série de obras, era necessário para a melhor delimitação do corpus a ser abordado.

No primeiro capítulo, apoiado nas lições de Saussure e seus desdobramentos, apontam-se caminhos para a distinção entre os diversos ramos do direito com base na análise sêmica, que comprova que não há sustentação semântica para a clássica distinção entre direito público e privado, como ficou claro com a análise das oposições semânticas entre o direito civil e direito penal, bem como entre o direito civil e o direito comercial e direito do trabalho.

Seguindo em frente, a pesquisa desenvolveu-se inserindo as Codificações Civis no sistema normativo brasileiro quando o aparato da semântica lexical mostrou-se de boa utilidade para a distinção das leis levando-se em consideração o quorum para a sua aprovação, as matérias que podem tratar, bem como as normas hierarquicamente superiores a que devem observar.

Conforme se viu, as Codificações Civis são leis ordinárias que se distinguem das demais leis por pretenderem exaurir todas as matérias referentes a determinado ramo do direito. É assim que as Codificações Civis prevêem todas as relações entre indivíduos em sociedade para a realização de seus atos privados, tais como adquirir e transferir patrimônio, assumir obrigações, constituir família.

Ainda valendo-se dos recursos da análise semântica, buscando-se em dicionários brasileiros o significado dos termos casamento e concubinato, iniciamos um estudo preliminar a respeito dos traços de significação que unem e distinguem tais institutos, todos versando sobre a união entre indivíduos por razões afetivas.

Já a esta altura, fez-se possível notar a importância do uso lingüístico para a depreensão do sentido dos signos e como os valores são a perfeita estampa da ideologia de determinada cultura em determinado momento histórico. 
Considerando que os dicionários são expressões da ideologia de um povo, o dicionário cunhado nos atos 70 do século passado não levava em consideração a distinção entre concubinato puro e impuro, uma vez que a sociedade, ainda sob a égide do Código Civil de 1916 e com o pensamento voltado para as tradições de séculos ainda anteriores, ou enxergava na união entre homem e mulher um casamento civil, que dava origem à família legítima e aos respectivos filhos legítimos, ou concubinato, carregado de sentido negativo.

A marginalização do concubinato também fica clara com a entrada do HOUAISS para o termo com base histórica que comprova que, desde tempos remotos, o signo concubinato sempre foi relegado a relacionamento amoroso de segunda categoria.

Já o dicionário mais moderno, RIDEEL, prevê duas possibilidades de acepção para o termo concubinato, sendo que ambas as definições deixaram claro a oposição entre elas. Pois, se uma mantinha seu caráter sub-reptício, a outra considerava a união de homem e mulher com todos os elementos que configuram o casamento civil, exceto a celebração do ato solene em si.

A análise do sistema normativo como processo, estudado com base na teoria semiótica de linha francesa, além de confirmar certos aspectos suscitados na análise da semântica lexical, tais como a distinção entre as normas jurídicas e as demais normas, especialmente pela construção do sistema jurídico, que sempre opera por meio da nãosincretização de papéis-actanciais, quer seja nas relações de coordenação entre os sujeitos, quer nas relações hierárquicas.

Mais do que isso, percebe-se que a sintaxe narrativa do discurso jurídico operase apoiada em uma dupla isotopia, uma originada no discurso jurídico e outra no discurso referencial, sendo justamente da intersecção desses níveis de linguagem que surgem os fenômenos de prática jurídica, ou seja, da produção jurídica e da verificação jurídica. 
Também por meio do aparato semiótico, em especial da noção de actante coletivo de Greimas, em um primeiro momento comprovou-se a eficácia do modelo eleito ao aplicá-lo para analisar os condomínios edilícios, que também se comportam (tal como as sociedades comerciais analisadas pelo autor) como actantes paradigmáticos.

Esse mesmo modelo serviu de apoio para analisar como a produção jurídica operou para tornar o instituto da união estável de relação concubinária à entidade familiar reconhecida por nossa Lei Maior, demonstrando-se como se aproxima do instituo do casamento, na medida em que ambos convergem para a sedimentação de união baseada no interesse em constituir família pura e simplesmente e não por questões precipuamente patrimoniais, que acabavam por euforizar o aspecto individual do homem e da mulher nas relações afetivas.

Foi assim com o casamento, que abole na atual Codificação Civil o instituto do regime dotal e privilegia o regime de separação parcial de bens, deixando livres os cônjuges de preocupações patrimoniais se têm a intenção de dissolver a união conjugal: aquilo que era de cada um antes do casamento, continua com seu proprietário; aquilo que foi conquistado em comum é partilhado igualmente entre eles.

Já com a união estável, criação jurisprudencial por excelência, em um primeiro momento observa-se que encontra seu caminho no discurso jurídico por meio de sua sumulação, que reconhece o direito da mulher na partilha de bens do homem, comprovando-se a sociedade de fato ainda, portanto, reconhecida pelo aspecto patrimonial e que, paulatinamente vê-se transformada em união afetiva na medida que os critérios para sua caracterização afastam-se de aspectos meramente patrimoniais.

Nota-se também que cada um dos institutos apresenta percursos narrativos distintos: o percurso do casamento civil, por ser determinado previamente pelo destinador-legislante, apresenta-se como uma narrativa da ação, em que o sujeito cumpre tarefas e é sancionado positivamente por elas para conquistar e permanecer em conjunção com seu objeto de valor. 
Já o percurso da união estável, por ser construção jurisprudencial, concentra-se na fase da sanção, preocupando-se apenas em descrever o percurso que deve percorrer o sujeito se quiser ser sancionado positivamente e ver reconhecida seu relacionamento conjugal como união estável.

Por meio das lições de Maingueneau, atingiu-se o objetivo de tratar o nível discursivo das codificações civis deslocando-se a instância da enunciação para o interdiscurso, isso porque a pretensão era a análise em oposição entre o Código Civil de 1916 e o Código Civil de 2002 e, mais do que isso, a confirmação da hipótese suscitada de que o discurso normativo é produto de vozes compartilhadas, de constituição heterogênea a partir de discursos de diferentes campos que dialogam entre si e com isso dão vida às normas jurídicas que regulamentam as relações em sociedade.

Muito do que se viu nos capítulos precedentes foi confirmado por meio da análise da semântica global das Codificações Civis, o que era de se esperar, uma vez que todos os pressupostos utilizados ao longo da dissertação partiam de um mesmo ponto: a análise do sentido por meio de elementos fornecidos pelo texto, seja na esfera lexical, seja em nível transfrasal ou mesmo interdiscursivo.

No último capítulo, as dificuldades encontradas dizem respeito à inexistência de estudos anteriores de aplicação da teoria do mestre francês a textos jurídicos, sendo certo que os dados obtidos devem ser considerados com a devida reserva, passíveis de releitura em análises futuras.

Mas, de qualquer modo, foi possível traçar aproximações do discurso jurídico com outras espécies de discurso, tais como poemas clássicos e letras de 'rock barato', quebrando-se um pouco o protocolo dos estudos na área de direito, sempre distantes da sua concepção discursiva, que permite que dialogue com discursos tão díspares e distantes de si.

Provavelmente esse tipo de postura se deva à própria forma de dizer da principal fonte de direito, ou seja, a norma jurídica que, para tornar-se voz que causa temor, valese de inflexões imperativas e distanciamentos no enunciado entre destinador e 
destinatário, dotando o discurso jurídico-normativo de uma forma peculiar de dizer sobre a vida dos indivíduos.

Além disso, ainda que de maneira despretensiosa, traçou-se uma possível distinção do discurso normativo entre os países que adotam codificações, de acordo com a tradição romana e os países que adotam o comon law, com base na concentração ou dispersão de seu sistema de regras.

Por fim, por meio da análise dos institutos do casamento e da união estável confirmou-se, agora já sob o aspecto discursivo, o papel da jurisprudência (verificação jurídica) para a transformação do ordenamento jurídico, sendo que é da interação do discurso jurídico normativo com os debates doutrinários sobre a norma que o direito incorpora os anseios da sociedade que a todo momento interferem nos mecanismos de prática jurídica, de onde conclui-se que são sempre os homems o destinatário da norma jurídica e também o seu enunciador, quer seja através da palavra jurisprudencial, quer seja pela palavra do legislador, ambos movidos pelas incessantes transformações do homem em sociedade, às quais o direito se amolda, graças aos mecanismos abordados ao longo de nossos estudos.

Da mesma forma que a união estável encontrou seu caminho no universo jurídico por meio da constante verificação da conformação do sistema jurídico aos anseios sociais, é com base nessa possibilidade de transformação que mudanças que virão serão incorporadas pelo ordenamento jurídico, tais como uniões homoafetivas, estatuto dos seres clonados e o que mais os homens puderem criar. 


\section{BIBLIOGRAFIA}

ACQUAVIVA, Marcus Cláudio. Notas Introdutórias ao Estudo do Direito. São Paulo. Ícone.

AUTHIER-REVUZ， J. (1990). Heterogeneidade(s) enunciativa(s). Cadernos Lingüístico. Campinas, UNICAMP, 19.

BAKTHIN, M. (1981). Problemas da poética de Dostoievski. Rio de Janeiro. Forense Universitária.

BARROS, Diana L. P. de. Teoria do Discurso - fundamentos semióticos. São Paulo. Humanitas.

BERTRAND, Denis (2003). Caminhos da Semiótica Literária. Tradução do Grupo CASA, sob a coordenação de Ivã Carlos Lopes, Edna Maria F. S. Nascimento, Mariza Bianconcini Teixiera Mendes, Marisa Giammecchini de Souza. Bauru. EDUSC.

BEVILAQUA, Clóvis. (1976). Teoria Geral do Direito Civil. Rio de Janeiro. Francisco Alves.

BUENO, Francisco da Silveira (1980). Dicionário Escolar da Língua Portuguesa. Rio de Janeiro. FENAME.

CAMÕES, Luis de (1982). Lírica. São Paulo. EDUSP.

CHARAUDEAU, Patrick/MAINGUENEAU, Dominique (2004). Dicionário de Análise do Discurso. São Paulo. Contexto.

COELHO, Fábio Ulhoa (1992). Manual de Direito Comercial. São Paulo. Saraiva.

COMPARATO, Fábio Konder (2006). Ética - direito, moral e religião no mundo moderno. São Paulo. Companhia das Letras.

DELMANTO, Celso (1991). Código Penal Comentado. São Paulo. Renovar

DINIZ, M.H. (1997). Curso de direito civil brasileiro. São Paulo. Saraiva. (2003). Código Civil Anotado. São Paulo. Saraiva

DISCINI, Norma. (2003). O estilo nos textos. ${ }^{97}$ São Paulo. Contexto. (2005). Comunicação nos textos. São Paulo. Contexto.

FERREIRA FILHO/ M. G. (1995). Curso de Direito Constitucional. São Paulo. Saraiva. FIORIN, J.L. (1996). As astúcias da enunciação. São Paulo. Cultrix (1998). Linguagem e ideologia.São Paulo. Ática 
(s/d). Algumas considerações sobre o medo e a vergonha. Cruzeiro semiótico,16. Porto. Portugal.

(2002). A linguagem em uso. Introdução à lingüística. São Paulo.

Contexto.

(2003). Pragmática. Introdução à lingüística. São Paulo. Contexto. org. (2002). Introdução à Lingüística - I. Objetos Teóricos. São Paulo.

Contexto.

org. (2002). Introdução à Lingüística - II. Princípios de Análise. São Paulo. Contexto.

FRAGOSO, Heleno (1991). Lições de Direito Penal - Parte Geral. São Paulo. Editora Forense.

GREIMAS, A.J./ COURTÉS, J. (1989). Dicionário de semiótica. São Paulo. Cultrix

GREIMAS, A.J. (1976). Semiótica e ciências sociais. São Paulo. Cultrix

LANDOWSKI, Eric (1989). Sociedade Refletida. Campinas. Pontes Editora.

LISBOA, Roberto Senise (2004). Manual de Direito Civil Vol. 1 - Teoria Geral do Direito Civil. São Paulo. Revista dos Tribunais.

(2004). Manual de Direito Civil Vol. 5 - Direito da Família e das Sucessões. São Paulo. Revista dos Tribunais.

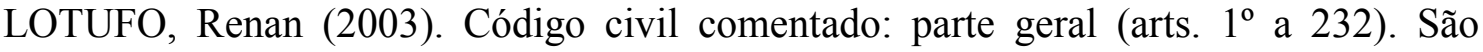
Paulo. Saraiva.

KELSEN, Hans (2003). Teoria Pura do Direito. São Paulo. Martins Fontes.

MAINGUENEAU, D. (2002). Análise dos textos de comunicação. São Paulo. Cortez. (1996). Pragmática para o discurso literário. São Paulo. Martins

Fontes.

(1989). Novas Tendências em análise do discurso. Campinas.

Pontes.

(2005). Gênese dos Discursos. Criar Edições.

MAMAN, Jeannette Antonios (2003). Fenomenologia Existencial do Direito - crítica do pensamento jurídico brasileiro. São Paulo. Quartier Latin.

MIRABETE, Julio Fabbrini. Manual de Direito Penal. Parte geral - Arts. $1^{\circ}$ a 120 do CP. $8^{\text {a }}$ Edição. São Paulo. Atlas

(1994). Manual de Direito Penal 2. São Paulo. Atlas.

MONTORO, André Franco (1993). Introdução à Ciência do Direito. São Paulo. Revista dos Tribunais. 
PIETROFORTE, A.V.S. (2002) in Em tempo. O discurso jurídico através do discurso literário.. Marília. Fundação de Ensino Eurípedes Soares da Rocha.

(2004). Semiótica Visual - os percursos do olhar. São Paulo.

Contexto.

REALE, Miguel. (2003). Estudos preliminares do código civil. São Paulo. Revista dos Tribunais.

. (2002). Filosofia do Direito. $4^{\text {a }}$ Edição. São Paulo. Saraiva. . (1979). Teoria tridimensional do direito. São Paulo. Saraiva.

RODRIGUES, Sílvio (1997). Direito Civil - Parte Geral. São Paulo. Saraiva.

VILELA Mário. (1979). Estruturas Léxicas do Português. Coimbra. Almedina.

VENOSA. S.S.(2003). Novo código civil: texto comparado. São Paulo. Atlas. (2000). Revista do Advogado. Março 2000, nº 58. São Paulo. AASP. (2000). Revista do Advogado. Novembro 2000, nº 61. São Paulo.

AASP. (2002). Revista do Advogado. Dezembro 2002, nº 68. São Paulo. AASP. (2006). Código Civil. São Paulo. Saraiva. (2006). Código Penal. São Paulo. Saraiva. (2006). Constituição da República Federativa do Brasil. São Paulo. Saraiva. 


\section{ANEXO I - CÓDIGO CIVIL DE 2002}

\section{CAPÍTULO VII}

\section{Do Condomínio Edilício}

\section{Seção I}

\section{Disposições Gerais}

Art. 1.331. Pode haver, em edificações, partes que são propriedade exclusiva, e partes que são propriedade comum dos condôminos.

$\S 1^{0}$ As partes suscetíveis de utilização independente, tais como apartamentos, escritórios, salas, lojas, sobrelojas ou abrigos para veículos, com as respectivas frações ideais no solo e nas outras partes comuns, sujeitam-se a propriedade exclusiva, podendo ser alienadas e gravadas livremente por seus proprietários.

$\S 2^{\circ} \mathrm{O}$ solo, a estrutura do prédio, o telhado, a rede geral de distribuição de água, esgoto, gás e eletricidade, a calefação e refrigeração centrais, e as demais partes comuns, inclusive o acesso ao logradouro público, são utilizados em comum pelos condôminos, não podendo ser alienados separadamente, ou divididos.

(Redação anterior) - $\S 3^{-0}$ A cada unidade imobiliária caberá, como parte inseparável, uma fração ideal no solo e nas outras partes comuns, que será identificada em forma decimal ou ordinária no instrumento de instituição do condomínio. (Redação da LEI No 10.931, DE 02 DE AGOSTO DE 2004)

$\S 3^{0} \mathrm{~A}$ fração ideal no solo e nas outras partes comuns é proporcional ao valor da unidade imobiliária, o qual se calcula em relação ao conjunto da edificação.

$\S 4^{\circ}$ Nenhuma unidade imobiliária pode ser privada do acesso ao logradouro público.

$\S 5^{\circ} \mathrm{O}$ terraço de cobertura é parte comum, salvo disposição contrária da escritura de constituição do condomínio.

Art. 1.332. Institui-se o condomínio edilício por ato entre vivos ou testamento, registrado no Cartório de Registro de Imóveis, devendo constar daquele ato, além do disposto em lei especial:

I - a discriminação e individualização das unidades de propriedade exclusiva, estremadas uma das outras e das partes comuns;

II - a determinação da fração ideal atribuída a cada unidade, relativamente ao terreno e partes comuns;

III - o fim a que as unidades se destinam.

Art. 1.333. A convenção que constitui o condomínio edilício deve ser subscrita pelos titulares de, no mínimo, dois terços das frações ideais e torna-se, desde logo, obrigatória para os titulares de direito sobre as unidades, ou para quantos sobre elas tenham posse ou detenção.

Parágrafo único. Para ser oponível contra terceiros, a convenção do condomínio deverá ser registrada no Cartório de Registro de Imóveis. 
Art. 1.334. Além das cláusulas referidas no art. 1.332 e das que os interessados houverem por bem estipular, a convenção determinará:

I - a quota proporcional e o modo de pagamento das contribuições dos condôminos para atender às despesas ordinárias e extraordinárias do condomínio;

II - sua forma de administração;

III - a competência das assembléias, forma de sua convocação e quorum exigido para as deliberações;

IV - as sanções a que estão sujeitos os condôminos, ou possuidores;

$\mathrm{V}$ - o regimento interno.

$\S 1^{\circ}$ A convenção poderá ser feita por escritura pública ou por instrumento particular.

$\S 2^{\underline{0}}$ São equiparados aos proprietários, para os fins deste artigo, salvo disposição em contrário, os promitentes compradores e os cessionários de direitos relativos às unidades autônomas.

Art. 1.335. São direitos do condômino:

I - usar, fruir e livremente dispor das suas unidades;

II - usar das partes comuns, conforme a sua destinação, e contanto que não exclua a utilização dos demais compossuidores;

III - votar nas deliberações da assembléia e delas participar, estando quite.

Art. 1.336. São deveres do condômino:

I - contribuir para as despesas do condomínio na proporção das suas frações ideais, salvo disposição em contrário na convenção; (Redação da LEI No 10.931, DE 02 DE AGOSTO DE 2004)

(Redação anterior) - I - Contribuir para as despesas do condomínio, na proporção de suas frações ideais;

II - não realizar obras que comprometam a segurança da edificação;

III - não alterar a forma e a cor da fachada, das partes e esquadrias externas;

IV - dar às suas partes a mesma destinação que tem a edificação, e não as utilizar de maneira prejudicial ao sossego, salubridade e segurança dos possuidores, ou aos bons costumes.

$\S 1^{0} \mathrm{O}$ condômino que não pagar a sua contribuição ficará sujeito aos juros moratórios convencionados ou, não sendo previstos, os de um por cento ao mês e multa de até dois por cento sobre o débito.

$\S 2^{0} \mathrm{O}$ condômino, que não cumprir qualquer dos deveres estabelecidos nos incisos II a IV, pagará a multa prevista no ato constitutivo ou na convenção, não podendo ela ser superior a cinco vezes o valor de suas contribuições mensais, independentemente das perdas e danos que se apurarem; não havendo disposição expressa, caberá à assembléia geral, por dois terços no mínimo dos condôminos restantes, deliberar sobre a cobrança da multa. 
Art. 1337. O condômino, ou possuidor, que não cumpre reiteradamente com os seus deveres perante o condomínio poderá, por deliberação de três quartos dos condôminos restantes, ser constrangido a pagar multa correspondente até ao quíntuplo do valor atribuído à contribuição para as despesas condominiais, conforme a gravidade das faltas e a reiteração, independentemente das perdas e danos que se apurem.

Parágrafo único. $\mathrm{O}$ condômino ou possuidor que, por seu reiterado comportamento anti-social, gerar incompatibilidade de convivência com os demais condôminos ou possuidores, poderá ser constrangido a pagar multa correspondente ao décuplo do valor atribuído à contribuição para as despesas condominiais, até ulterior deliberação da assembléia.

Art. 1.338. Resolvendo o condômino alugar área no abrigo para veículos, preferir-se-á, em condições iguais, qualquer dos condôminos a estranhos, e, entre todos, os possuidores.

Art. 1.339. Os direitos de cada condômino às partes comuns são inseparáveis de sua propriedade exclusiva; são também inseparáveis das frações ideais correspondentes as unidades imobiliárias, com as suas partes acessórias.

$\S 1^{\circ}$ Nos casos deste artigo é proibido alienar ou gravar os bens em separado.

$\S 2^{\underline{o}}$ É permitido ao condômino alienar parte acessória de sua unidade imobiliária a outro condômino, só podendo fazê-lo a terceiro se essa faculdade constar do ato constitutivo do condomínio, e se a ela não se opuser a respectiva assembléia geral.

Art. 1.340. As despesas relativas a partes comuns de uso exclusivo de um condômino, ou de alguns deles, incumbem a quem delas se serve.

Art. 1.341. A realização de obras no condomínio depende:

I - se voluptuárias, de voto de dois terços dos condôminos;

II - se úteis, de voto da maioria dos condôminos.

$\S 1^{\underline{0}}$ As obras ou reparações necessárias podem ser realizadas, independentemente de autorização, pelo síndico, ou, em caso de omissão ou impedimento deste, por qualquer condômino.

$\S 2^{\underline{0}} \mathrm{Se}$ as obras ou reparos necessários forem urgentes e importarem em despesas excessivas, determinada sua realização, o síndico ou o condômino que tomou a iniciativa delas dará ciência à assembléia, que deverá ser convocada imediatamente.

$\S 3^{0}$ Não sendo urgentes, as obras ou reparos necessários, que importarem em despesas excessivas, somente poderão ser efetuadas após autorização da assembléia, especialmente convocada pelo síndico, ou, em caso de omissão ou impedimento deste, por qualquer dos condôminos.

$\S 4^{\circ} \mathrm{O}$ condômino que realizar obras ou reparos necessários será reembolsado das despesas que efetuar, não tendo direito à restituição das que fizer com obras ou reparos de outra natureza, embora de interesse comum.

Art. 1.342. A realização de obras, em partes comuns, em acréscimo às já existentes, a fim de lhes facilitar ou aumentar a utilização, depende da aprovação de dois terços dos votos dos condôminos, não sendo permitidas 
construções, nas partes comuns, suscetíveis de prejudicar a utilização, por qualquer dos condôminos, das partes próprias, ou comuns.

Art. 1.343. A construção de outro pavimento, ou, no solo comum, de outro edifício, destinado a conter novas unidades imobiliárias, depende da aprovação da unanimidade dos condôminos.

Art. 1.344. Ao proprietário do terraço de cobertura incumbem as despesas da sua conservação, de modo que não haja danos às unidades imobiliárias inferiores.

Art. 1.345. O adquirente de unidade responde pelos débitos do alienante, em relação ao condomínio, inclusive multas e juros moratórios.

Art. 1.346. É obrigatório o seguro de toda a edificação contra o risco de incêndio ou destruição, total ou parcial.

\section{Seção II}

\section{Da Administração do Condomínio}

Art. 1.347. A assembléia escolherá um síndico, que poderá não ser condômino, para administrar o condomínio, por prazo não superior a dois anos, o qual poderá renovar-se.

Art. 1.348. Compete ao síndico:

I - convocar a assembléia dos condôminos;

II - representar, ativa e passivamente, o condomínio, praticando, em juízo ou fora dele, os atos necessários à defesa dos interesses comuns;

III - dar imediato conhecimento à assembléia da existência de procedimento judicial ou administrativo, de interesse do condomínio;

IV - cumprir e fazer cumprir a convenção, o regimento interno e as determinações da assembléia;

V - diligenciar a conservação e a guarda das partes comuns e zelar pela prestação dos serviços que interessem aos possuidores;

VI - elaborar o orçamento da receita e da despesa relativa a cada ano;

VII - cobrar dos condôminos as suas contribuições, bem como impor e cobrar as multas devidas;

VIII - prestar contas à assembléia, anualmente e quando exigidas;

IX - realizar o seguro da edificação.

$\S 1^{\circ}$ Poderá a assembléia investir outra pessoa, em lugar do síndico, em poderes de representação.

$\S 2^{\circ} \mathrm{O}$ síndico pode transferir a outrem, total ou parcialmente, os poderes de representação ou as funções administrativas, mediante aprovação da assembléia, salvo disposição em contrário da convenção.

Art. 1.349. A assembléia, especialmente convocada para o fim estabelecido no $\S 2^{\underline{o}}$ do artigo antecedente, poderá, pelo voto da maioria absoluta de seus 
membros, destituir o síndico que praticar irregularidades, não prestar contas, ou não administrar convenientemente o condomínio.

Art. 1.350. Convocará o síndico, anualmente, reunião da assembléia dos condôminos, na forma prevista na convenção, a fim de aprovar o orçamento das despesas, as contribuições dos condôminos e a prestação de contas, e eventualmente eleger-lhe o substituto e alterar o regimento interno.

$\S 1^{0}$ Se o síndico não convocar a assembléia, um quarto dos condôminos poderá fazê-lo.

$\S 2^{\circ}$ Se a assembléia não se reunir, o juiz decidirá, a requerimento de qualquer condômino.

Art. 1.351. Depende da aprovação de $2 / 3$ (dois terços) dos votos dos condôminos a alteração da convenção; a mudança da destinação do edifício, ou da unidade imobiliária, depende da aprovação pela unanimidade dos condôminos." (NR) (Redação da LEI No 10.931, DE 02 DE AGOSTO DE 2004)

(Redação anterior) - Art. 1.351. Depende da aprovação de dois terços dos votos dos condôminos a alteração da convenção e do regimento interno; a mudança da destinação do edifício, ou da unidade imobiliária, depende de aprovação pela unanimidade dos condôminos.

Art. 1.352. Salvo quando exigido quorum especial, as deliberações da assembléia serão tomadas, em primeira convocação, por maioria de votos dos condôminos presentes que representem pelo menos metade das frações ideais.

Parágrafo único. Os votos serão proporcionais às frações ideais no solo e nas outras partes comuns pertencentes a cada condômino, salvo disposição diversa da convenção de constituição do condomínio.

Art. 1.353. Em segunda convocação, a assembléia poderá deliberar por maioria dos votos dos presentes, salvo quando exigido quorum especial.

Art. 1.354. A assembléia não poderá deliberar se todos os condôminos não forem convocados para a reunião.

Art. 1.355. Assembléias extraordinárias poderão ser convocadas pelo síndico ou por um quarto dos condôminos.

Art. 1.356. Poderá haver no condomínio um conselho fiscal, composto de três membros, eleitos pela assembléia, por prazo não superior a dois anos, ao qual compete dar parecer sobre as contas do síndico. 
ANEXO II - CÓDIGO CIVIL DE 2002

\section{CÓDIGO CIVIL DE 2002}

\section{LIVRO IV - DO DIREITO DE FAMÍLIA}

\section{TÍTULO I - Do Direito Pessoal}

SUBTÍTULO I - Do Casamento

\section{CAPÌTULO I}

\section{Disposições gerais}

Art. 1.511. O casamento estabelece comunhão plena de vida, com base na igualdade de direitos e deveres dos cônjuges.

Art. 1.512. O casamento é civil e gratuita a sua celebração.

Parágrafo único. A habilitação para o casamento, o registro e a primeira certidão serão isentos de selos, emolumentos e custas, para as pessoas cuja pobreza for declarada, sob as penas da lei.

Art. 1.513. É defeso a qualquer pessoa, de direito público ou privado, interferir na comunhão de vida instituída pela família.

Art. 1.514. O casamento se realiza no momento em que o homem e a mulher manifestam, perante o juiz, a sua vontade de estabelecer vínculo conjugal, e o juiz os declara casados.

Art. 1.515. O casamento religioso, que atender às exigências da lei para a validade do casamento civil, equipara-se a este, desde que registrado no registro próprio, produzindo efeitos a partir da data de sua celebração.

Art. 1.516. O registro do casamento religioso submete-se aos mesmos requisitos exigidos para o casamento civil.

$\S 1^{\circ} \mathrm{O}$ registro civil do casamento religioso deverá ser promovido dentro de noventa dias de sua realização, mediante comunicação do celebrante ao ofício competente, ou por iniciativa de qualquer interessado, desde que haja sido homologada previamente a habilitação regulada neste Código. Após o referido prazo, o registro dependerá de nova habilitação.

$\S 2^{\circ} \mathrm{O}$ casamento religioso, celebrado sem as formalidades exigidas neste Código, terá efeitos civis se, a requerimento do casal, for registrado, a qualquer tempo, no registro civil, mediante prévia habilitação perante a autoridade competente e observado o prazo do art. 1.532.

$\S 3^{\circ}$ Será nulo o registro civil do casamento religioso se, antes dele, qualquer dos consorciados houver contraído com outrem casamento civil.

\section{CAPÌTULO II}

Da Capacidade para o casamento 
Art. 1.517. O homem e a mulher com dezesseis anos podem casar, exigindo-se autorização de ambos os pais, ou de seus representantes legais, enquanto não atingida a maioridade civil.

Parágrafo único. Se houver divergência entre os pais, aplica-se o disposto no parágrafo único do art. 1.631 .

Art. 1.518. Até à celebração do casamento podem os pais, tutores ou curadores revogar a autorização.

Art. 1.519. A denegação do consentimento, quando injusta, pode ser suprida pelo juiz.

Art. 1.520. Excepcionalmente, será permitido o casamento de quem ainda não alcançou a idade núbil (art. 1517), para evitar imposição ou cumprimento de pena criminal ou em caso de gravidez.

\section{CAPÍTULO III}

\section{Dos Impedimentos}

Art. 1.521. Não podem casar:

I - os ascendentes com os descendentes, seja o parentesco natural ou civil;

II - os afins em linha reta;

III - o adotante com quem foi cônjuge do adotado e o adotado com quem o foi do adotante;

IV - os irmãos, unilaterais ou bilaterais, e demais colaterais, até o terceiro grau inclusive;

V - o adotado com o filho do adotante;

VI - as pessoas casadas;

VII - o cônjuge sobrevivente com o condenado por homicídio ou tentativa de homicídio contra o seu consorte.

Art. 1.522. Os impedimentos podem ser opostos, até o momento da celebração do casamento, por qualquer pessoa capaz.

Parágrafo único. Se o juiz, ou o oficial de registro, tiver conhecimento da existência de algum impedimento, será obrigado a declará-lo.

\section{CAPÌTULO IV}

\section{Das causas suspensivas}

Art. 1.523. Não devem casar:

I - o viúvo ou a viúva que tiver filho do cônjuge falecido, enquanto não fizer inventário dos bens do casal e der partilha aos herdeiros; 
II - a viúva, ou a mulher cujo casamento se desfez por ser nulo ou ter sido anulado, até dez meses depois do começo da viuvez, ou da dissolução da sociedade conjugal;

III - o divorciado, enquanto não houver sido homologada ou decidida a partilha dos bens do casal;

IV - o tutor ou o curador e os seus descendentes, ascendentes, irmãos, cunhados ou sobrinhos, com a pessoa tutelada ou curatelada, enquanto não cessar a tutela ou curatela, e não estiverem saldadas as respectivas contas.

Parágrafo único. É permitido aos nubentes solicitar ao juiz que não lhes sejam aplicadas as causas suspensivas previstas nos incisos I, III e IV deste artigo, provando-se a inexistência de prejuízo, respectivamente, para o herdeiro, para o ex-cônjuge e para a pessoa tutelada ou curatelada; no caso do inciso II, a nubente deverá provar nascimento de filho, ou inexistência de gravidez, na fluência do prazo.

Art. 1.524. As causas suspensivas da celebração do casamento podem ser argüidas pelos parentes em linha reta de um dos nubentes, sejam consangüíneos ou afins, e pelos colaterais em segundo grau, sejam também consangüíneos ou afins.

\section{CAPÍTULO V}

\section{Do Processo de Habilitação para o Casamento}

Art. 1.525. O requerimento de habilitação para o casamento será firmado por ambos os nubentes, de próprio punho, ou, a seu pedido, por procurador, e deve ser instruído com os seguintes documentos:

I - certidão de nascimento ou documento equivalente;

II - autorização por escrito das pessoas sob cuja dependência legal estiverem, ou ato judicial que a supra;

III - declaração de duas testemunhas maiores, parentes ou não, que atestem conhecê-los e afirmem não existir impedimento que os iniba de casar;

IV - declaração do estado civil, do domicílio e da residência atual dos contraentes e de seus pais, se forem conhecidos;

V - certidão de óbito do cônjuge falecido, de sentença declaratória de nulidade ou de anulação de casamento, transitada em julgado, ou do registro da sentença de divórcio.

Art. 1.526. A habilitação será feita perante o oficial do Registro Civil e, após a audiência do Ministério Público, será homologada pelo juiz.

Art. 1.527. Estando em ordem a documentação, o oficial extrairá o edital, que se afixará durante quinze dias nas circunscrições do Registro Civil de ambos os nubentes, e, obrigatoriamente, se publicará na imprensa local, se houver.

Parágrafo único. A autoridade competente, havendo urgência, poderá dispensar a publicação.

Art. 1.528. É dever do oficial do registro esclarecer os nubentes a respeito dos fatos que podem ocasionar a invalidade do casamento, bem como sobre os diversos regimes de bens.

Art. 1.529. Tanto os impedimentos quanto as causas suspensivas serão opostos em declaração escrita e assinada, instruída com as provas do fato alegado, ou com a indicação do lugar onde possam ser obtidas. 
Art. 1.530. O oficial do registro dará aos nubentes ou a seus representantes nota da oposição, indicando os fundamentos, as provas e o nome de quem a ofereceu.

Parágrafo único. Podem os nubentes requerer prazo razoável para fazer prova contrária aos fatos alegados, e promover as ações civis e criminais contra o oponente de má-fé.

Art. 1.531. Cumpridas as formalidades dos arts. 1.526 e 1.527 e verificada a inexistência de fato obstativo, o oficial do registro extrairá o certificado de habilitação.

Art. 1.532. A eficácia da habilitação será de noventa dias, a contar da data em que foi extraído o certificado.

\section{CAPÍTULO VI}

\section{Da Celebração do Casamento}

Art. 1.533. Celebrar-se-á o casamento, no dia, hora e lugar previamente designados pela autoridade que houver de presidir o ato, mediante petição dos contraentes,

que se mostrem habilitados com a certidão do art. 1.531.

Art. 1.534. A solenidade realizar-se-á na sede do cartório, com toda publicidade, a portas abertas, presentes pelo menos duas testemunhas, parentes ou não dos contraentes, ou, querendo as partes e consentindo a autoridade celebrante, noutro edifício público ou particular.

$\S 1^{\circ}$ Quando o casamento for em edifício particular, ficará este de portas abertas durante o ato.

$\S 2^{\circ}$ Serão quatro as testemunhas na hipótese do parágrafo anterior e se algum dos contraentes não souber ou não puder escrever.

Art. 1.535. Presentes os contraentes, em pessoa ou por procurador especial, juntamente com as testemunhas e o oficial do registro, o presidente do ato, ouvida aos nubentes a afirmação de que pretendem casar por livre e espontânea vontade, declarará efetuado o casamento, nestes termos:

"De acordo com a vontade que ambos acabais de afirmar perante mim, de vos receberdes por marido e mulher, eu, em nome da lei, vos declaro casados."

Art. 1.536. Do casamento, logo depois de celebrado, lavrar-se-á o assento no livro de registro. No assento, assinado pelo presidente do ato, pelos cônjuges, as testemunhas, e o oficial do registro, serão exarados:

I - os prenomes, sobrenomes, datas de nascimento, profissão, domicílio e residência atual dos cônjuges;

II - os prenomes, sobrenomes, datas de nascimento ou de morte, domicílio e residência atual dos pais;

III - o prenome e sobrenome do cônjuge precedente e a data da dissolução do casamento anterior;

IV - a data da publicação dos proclamas e da celebração do casamento;

$\mathrm{V}$ - a relação dos documentos apresentados ao oficial do registro;

VI - o prenome, sobrenome, profissão, domicílio e residência atual das testemunhas;

VII - o regime do casamento, com a declaração da data e do cartório em cujas notas foi lavrada a escritura antenupcial, quando o regime não for o da comunhão parcial, ou o obrigatoriamente estabelecido. 
Art. 1.537. O instrumento da autorização para casar transcrever-se-á integralmente na escritura antenupcial.

Art. 1.538. A celebração do casamento será imediatamente suspensa se algum dos contraentes:

I - recusar a solene afirmação da sua vontade;

II - declarar que esta não é livre e espontânea;

III - manifestar-se arrependido.

Parágrafo único. O nubente que, por algum dos fatos mencionados neste artigo, der causa à suspensão do ato, não será admitido a retratar-se no mesmo dia.

Art. 1.539. No caso de moléstia grave de um dos nubentes, o presidente do ato irá celebrá-lo onde se encontrar o impedido, sendo urgente, ainda que à noite, perante duas testemunhas que saibam ler e escrever.

$\S 1^{\underline{0}}$ A falta ou impedimento da autoridade competente para presidir o casamento suprir-se-á por qualquer dos seus substitutos legais, e a do oficial do Registro Civil por outro ad hoc, nomeado pelo presidente do ato.

$\S 2^{\circ} \mathrm{O}$ termo avulso, lavrado pelo oficial ad hoc, será registrado no respectivo registro dentro em cinco dias, perante duas testemunhas, ficando arquivado.

Art. 1.540. Quando algum dos contraentes estiver em iminente risco de vida, não obtendo a presença da autoridade à qual incumba presidir o ato, nem a de seu substituto, poderá o casamento ser celebrado na presença de seis testemunhas, que com os nubentes não tenham parentesco em linha reta, ou, na colateral, até segundo grau.

Art. 1.541. Realizado o casamento, devem as testemunhas comparecer perante a autoridade judicial mais próxima, dentro em dez dias, pedindo que lhes tome por termo a declaração de:

I - que foram convocadas por parte do enfermo;

II - que este parecia em perigo de vida, mas em seu juízo;

III - que, em sua presença, declararam os contraentes, livre e espontaneamente, receber-se por marido e mulher.

$\S 1^{\underline{0}}$ Autuado o pedido e tomadas as declarações, o juiz procederá às diligências necessárias para verificar se os contraentes podiam ter-se habilitado, na forma ordinária, ouvidos os interessados que o requererem, dentro em quinze dias.

$\S 2^{\underline{0}}$ Verificada a idoneidade dos cônjuges para o casamento, assim o decidirá a autoridade competente, com recurso voluntário às partes.

$\S 3^{0}$ Se da decisão não se tiver recorrido, ou se ela passar em julgado, apesar dos recursos interpostos, o juiz mandará registrá-la no livro do Registro dos Casamentos.

$\S 4^{\underline{0}} \mathrm{O}$ assento assim lavrado retrotrairá os efeitos do casamento, quanto ao estado dos cônjuges, à data da celebração.

$\S 5^{\circ}$ Serão dispensadas as formalidades deste e do artigo antecedente, se o enfermo convalescer e puder ratificar o casamento na presença da autoridade competente e do oficial do registro.

Art. 1.542. O casamento pode celebrar-se mediante procuração, por instrumento público, com poderes especiais. 
$\S 1^{0}$ A revogação do mandato não necessita chegar ao conhecimento do mandatário; mas, celebrado o casamento sem que o mandatário ou o outro contraente tivessem ciência da revogação, responderá o mandante por perdas e danos.

$\S 2^{\underline{0}} \mathrm{O}$ nubente que não estiver em iminente risco de vida poderá fazer-se representar no casamento nuncupativo.

$\S 3^{0}$ A eficácia do mandato não ultrapassará noventa dias.

$\S 4^{\circ}$ Só por instrumento público se poderá revogar o mandato.

\section{CAPÍTULO VII}

\section{Das Provas do Casamento}

Art. 1.543. O casamento celebrado no Brasil prova-se pela certidão do registro.

Parágrafo único. Justificada a falta ou perda do registro civil, é admissível qualquer outra espécie de prova.

Art. 1.544. O casamento de brasileiro, celebrado no estrangeiro, perante as respectivas autoridades ou os cônsules brasileiros, deverá ser registrado em cento e oitenta dias, a contar da volta de um ou de ambos os cônjuges ao Brasil, no cartório do respectivo domicílio, ou, em sua falta, no $1^{\circ}$ Ofício da Capital do Estado em que passarem a residir.

Art. 1.545. O casamento de pessoas que, na posse do estado de casadas, não possam manifestar vontade, ou tenham falecido, não se pode contestar em prejuízo da prole comum, salvo mediante certidão do Registro Civil que prove que já era casada alguma delas, quando contraiu o casamento impugnado.

Art. 1.546. Quando a prova da celebração legal do casamento resultar de processo judicial, o registro da sentença no livro do Registro Civil produzirá, tanto no que toca aos cônjuges como no que respeita aos filhos, todos os efeitos civis desde a data do casamento.

Art. 1.547. Na dúvida entre as provas favoráveis e contrárias, julgar-se-á pelo casamento, se os cônjuges, cujo casamento se impugna, viverem ou tiverem vivido na posse do estado de casados.

\section{CAPÍTULO VIII}

\section{Da invalidade do Casamento}

Art. 1.548. É nulo o casamento contraído:

I - pelo enfermo mental sem o necessário discernimento para os atos da vida civil;

II - por infringência de impedimento.

Art. 1.549. A decretação de nulidade de casamento, pelos motivos previstos no artigo antecedente, pode ser promovida mediante ação direta, por qualquer interessado, ou pelo Ministério Público.

Art. 1.550. É anulável o casamento:

I - de quem não completou a idade mínima para casar;

II - do menor em idade núbil, quando não autorizado por seu representante legal; 
III - por vício da vontade, nos termos dos arts. 1.556 a 1.558;

IV - do incapaz de consentir ou manifestar, de modo inequívoco, o consentimento;

V - realizado pelo mandatário, sem que ele ou o outro contraente soubesse da revogação do mandato, e não sobrevindo coabitação entre os cônjuges;

VI - por incompetência da autoridade celebrante.

Parágrafo único. Equipara-se à revogação a invalidade do mandato judicialmente decretada.

Art. 1.551. Não se anulará, por motivo de idade, o casamento de que resultou gravidez.

Art. 1.552. A anulação do casamento dos menores de dezesseis anos será requerida:

I - pelo próprio cônjuge menor;

II - por seus representantes legais;

III - por seus ascendentes.

Art. 1.553. O menor que não atingiu a idade núbil poderá, depois de completá-la, confirmar seu casamento, com a autorização de seus representantes legais, se necessária, ou com suprimento judicial.

Art. 1.554. Subsiste o casamento celebrado por aquele que, sem possuir a competência exigida na lei, exercer publicamente as funções de juiz de casamentos e, nessa qualidade, tiver registrado o ato no Registro Civil.

Art. 1.555. O casamento do menor em idade núbil, quando não autorizado por seu representante legal, só poderá ser anulado se a ação for proposta em cento e oitenta dias, por iniciativa do incapaz, ao deixar de sê-lo, de seus representantes legais ou de seus herdeiros necessários.

$\S 1^{\circ} \mathrm{O}$ prazo estabelecido neste artigo será contado do dia em que cessou a incapacidade, no primeiro caso; a partir do casamento, no segundo; e, no terceiro, da morte do incapaz.

$\S 2^{\underline{0}}$ Não se anulará o casamento quando à sua celebração houverem assistido os representantes legais do incapaz, ou tiverem, por qualquer modo, manifestado sua aprovação.

Art. 1.556. O casamento pode ser anulado por vício da vontade, se houve por parte de um dos nubentes, ao consentir, erro essencial quanto à pessoa do outro.

Art. 1.557. Considera-se erro essencial sobre a pessoa do outro cônjuge:

I - o que diz respeito à sua identidade, sua honra e boa fama, sendo esse erro tal que o seu conhecimento ulterior torne insuportável a vida em comum ao cônjuge enganado;

II - a ignorância de crime, anterior ao casamento, que, por sua natureza, torne insuportável a vida conjugal;

III - a ignorância, anterior ao casamento, de defeito físico irremediável, ou de moléstia grave e transmissível, pelo contágio ou herança, capaz de pôr em risco a saúde do outro cônjuge ou de sua descendência;

IV - a ignorância, anterior ao casamento, de doença mental grave que, por sua natureza, torne insuportável a vida em comum ao cônjuge enganado. 
Art. 1.558. É anulável o casamento em virtude de coação, quando o consentimento de um ou de ambos os cônjuges houver sido captado mediante fundado temor de mal considerável e iminente para a vida, a saúde e a honra, sua ou de seus familiares.

Art. 1.559. Somente o cônjuge que incidiu em erro, ou sofreu coação, pode demandar a anulação do casamento; mas a coabitação, havendo ciência do vício, valida o ato, ressalvadas as hipóteses dos incisos III e IV do art. 1.557.

Art. 1.560. O prazo para ser intentada a ação de anulação do casamento, a contar da data da celebração, é de:

I - cento e oitenta dias, no caso do inciso IV do art. 1.550;

II - dois anos, se incompetente a autoridade celebrante;

III - três anos, nos casos dos incisos I a IV do art. 1.557;

IV - quatro anos, se houver coação.

$\S 1^{0}$ Extingue-se, em cento e oitenta dias, o direito de anular o casamento dos menores de dezesseis anos, contado o prazo para o menor do dia em que perfez essa idade; e da data do casamento, para seus representantes legais ou ascendentes.

$\S 2^{\circ} \mathrm{Na}$ hipótese do inciso $\mathrm{V}$ do art. 1.550 , o prazo para anulação do casamento é de cento e oitenta dias, a partir da data em que o mandante tiver conhecimento da celebração.

Art. 1.561. Embora anulável ou mesmo nulo, se contraído de boa-fé por ambos os cônjuges, o casamento, em relação a estes como aos filhos, produz todos os efeitos até o dia da sentença anulatória.

$\S 1^{0}$ Se um dos cônjuges estava de boa-fé ao celebrar o casamento, os seus efeitos civis só a ele e aos filhos aproveitarão.

$\S 2^{\circ}$ Se ambos os cônjuges estavam de má-fé ao celebrar o casamento, os seus efeitos civis só aos filhos aproveitarão.

Art. 1.562. Antes de mover a ação de nulidade do casamento, a de anulação, a de separação judicial, a de divórcio direto ou a de dissolução de união estável, poderá requerer a parte, comprovando sua necessidade, a separação de corpos, que será concedida pelo juiz com a possível brevidade.

Art. 1.563. A sentença que decretar a nulidade do casamento retroagirá à data da sua celebração, sem prejudicar a aquisição de direitos, a título oneroso, por terceiros de boa-fé, nem a resultante de sentença transitada em julgado.

Art. 1.564. Quando o casamento for anulado por culpa de um dos cônjuges, este incorrerá:

I - na perda de todas as vantagens havidas do cônjuge inocente;

II - na obrigação de cumprir as promessas que lhe fez no contrato antenupcial.

\section{CAPÍTULO IX}

\section{Da Eficácia do Casamento}

Art. 1.565. Pelo casamento, homem e mulher assumem mutuamente a condição de consortes, companheiros e responsáveis pelos encargos da família.

$\S 1^{\circ}$ Qualquer dos nubentes, querendo, poderá acrescer ao seu o sobrenome do outro. 
$\S 2^{\circ}$ O planejamento familiar é de livre decisão do casal, competindo ao Estado propiciar recursos educacionais e financeiros para o exercício desse direito, vedado qualquer tipo de coerção por parte de instituições privadas ou públicas.

Art. 1.566. São deveres de ambos os cônjuges:

I - fidelidade recíproca;

II - vida em comum, no domicílio conjugal;

III - mútua assistência;

IV - sustento, guarda e educação dos filhos;

V - respeito e consideração mútuos.

Art. 1.567. A direção da sociedade conjugal será exercida, em colaboração, pelo marido e pela mulher, sempre no interesse do casal e dos filhos.

Parágrafo único. Havendo divergência, qualquer dos cônjuges poderá recorrer ao juiz, que decidirá tendo em consideração aqueles interesses.

Art. 1.568. Os cônjuges são obrigados a concorrer, na proporção de seus bens e dos rendimentos do trabalho, para o sustento da família e a educação dos filhos, qualquer que seja o regime patrimonial.

Art. 1.569. O domicílio do casal será escolhido por ambos os cônjuges, mas um e outro podem ausentar-se do domicílio conjugal para atender a encargos públicos, ao exercício de sua profissão, ou a interesses particulares relevantes.

Art. 1.570. Se qualquer dos cônjuges estiver em lugar remoto ou não sabido, encarcerado por mais de cento e oitenta dias, interditado judicialmente ou privado, episodicamente, de consciência, em virtude de enfermidade ou de acidente, o outro

exercerá com exclusividade a direção da família, cabendo-lhe a administração dos bens.

\section{TÍTULO II}

\section{Do Direito patrimonial}

\section{SUBTÍTULO I}

\section{Do Regime de Bens entre os Cônjuges}

\section{CAPÍTULO I}

\section{Disposições gerais}

Art. 1.639. É lícito aos nubentes, antes de celebrado o casamento, estipular, quanto aos seus bens, o que lhes aprouver.

$\S 1^{\underline{0}} \mathrm{O}$ regime de bens entre os cônjuges começa a vigorar desde a data do casamento.

$\S 2^{0}$ É admissível alteração do regime de bens, mediante autorização judicial em pedido motivado de ambos os cônjuges, apurada a procedência das razões invocadas e ressalvados os direitos de terceiros.

Art. 1.640. Não havendo convenção, ou sendo ela nula ou ineficaz, vigorará, quanto aos bens entre os cônjuges, o regime da comunhão parcial. 
Parágrafo único. Poderão os nubentes, no processo de habilitação, optar por qualquer dos regimes que este código regula. Quanto à forma, reduzir-se-á a termo a opção pela comunhão parcial, fazendo-se o pacto antenupcial por escritura pública, nas demais escolhas.

Art. 1.641. É obrigatório o regime da separação de bens no casamento:

I - das pessoas que o contraírem com inobservância das causas suspensivas da celebração do casamento;

II - da pessoa maior de sessenta anos;

III - de todos os que dependerem, para casar, de suprimento judicial.

Art. 1.642. Qualquer que seja o regime de bens, tanto o marido quanto a mulher podem livremente:

I - praticar todos os atos de disposição e de administração necessários ao desempenho de sua profissão, com as limitações estabelecida no inciso I do art. 1.647;

II - administrar os bens próprios;

III - desobrigar ou reivindicar os imóveis que tenham sido gravados ou alienados sem o seu consentimento ou sem suprimento judicial;

IV - demandar a rescisão dos contratos de fiança e doação, ou a invalidação do aval, realizados pelo outro cônjuge com infração do disposto nos incisos III e IV do art. 1.647;

$\mathrm{V}$ - reivindicar os bens comuns, móveis ou imóveis, doados ou transferidos pelo outro cônjuge ao concubino, desde que provado que os bens não foram adquiridos pelo esforço comum destes, se o casal estiver separado de fato por mais de cinco anos;

VI - praticar todos os atos que não lhes forem vedados expressamente.

Art. 1.643. Podem os cônjuges, independentemente de autorização um do outro:

I - comprar, ainda a crédito, as coisas necessárias à economia doméstica;

II - obter, por empréstimo, as quantias que a aquisição dessas coisas possa exigir.

Art. 1.644. As dívidas contraídas para os fins do artigo antecedente obrigam solidariamente ambos os cônjuges.

Art. 1.645. As ações fundadas nos incisos III, IV e V do art. 1.642 competem ao cônjuge prejudicado e a seus herdeiros.

Art. 1.646. No caso dos incisos III e IV do art. 1.642, o terceiro, prejudicado com a sentença favorável ao autor, terá direito regressivo contra o cônjuge, que realizou o negócio jurídico, ou seus herdeiros.

Art. 1.647. Ressalvado o disposto no art. 1.648, nenhum dos cônjuges pode, sem autorização do outro, exceto no regime da separação absoluta:

I - alienar ou gravar de ônus real os bens imóveis;

II - pleitear, como autor ou réu, acerca desses bens ou direitos;

III - prestar fiança ou aval; 
IV - fazer doação, não sendo remuneratória, de bens comuns, ou dos que possam integrar futura meação.

Parágrafo único. São válidas as doações nupciais feitas aos filhos quando casarem ou estabelecerem economia separada.

Art. 1.648. Cabe ao juiz, nos casos do artigo antecedente, suprir a outorga, quando um dos cônjuges a denegue sem motivo justo, ou lhe seja impossível concedê-la.

Art. 1.649. A falta de autorização, não suprida pelo juiz, quando necessária (art. 1.647), tornará anulável o ato praticado, podendo o outro cônjuge pleitear-lhe a anulação, até dois anos depois de terminada a sociedade conjugal.

Parágrafo único. A aprovação torna válido o ato, desde que feita por instrumento público, ou particular, autenticado.

Art. 1.650. A decretação de invalidade dos atos praticados sem outorga, sem consentimento, ou sem suprimento do juiz, só poderá ser demandada pelo cônjuge a quem cabia concedê-la, ou por seus herdeiros.

Art. 1.651. Quando um dos cônjuges não puder exercer a administração dos bens que lhe incumbe, segundo o regime de bens, caberá ao outro:

I - gerir os bens comuns e os do consorte;

II - alienar os bens móveis comuns;

III - alienar os imóveis comuns e os móveis ou imóveis do consorte, mediante autorização judicial.

Art. 1.652. O cônjuge, que estiver na posse dos bens particulares do outro, será para com este e seus herdeiros responsável:

I - como usufrutuário, se o rendimento for comum;

II - como procurador, se tiver mandato expresso ou tácito para os administrar;

III - como depositário, se não for usufrutuário, nem administrador.

\section{CAPÍTULO II}

\section{Do pacto antenupcial}

Art. 1.653. É nulo o pacto antenupcial se não for feito por escritura pública, e ineficaz se não lhe seguir o casamento.

Art. 1.654. A eficácia do pacto antenupcial, realizado por menor, fica condicionada à aprovação de seu representante legal, salvo as hipóteses de regime obrigatório de separação de bens.

Art. 1.655. É nula a convenção ou cláusula dela que contravenha disposição absoluta de lei.

Art. 1.656. No pacto antenupcial, que adotar o regime de participação final nos aqüestos, poderse-á convencionar a livre disposição dos bens imóveis, desde que particulares. 
Art. 1.657. As convenções antenupciais não terão efeito perante terceiros senão depois de registradas, em livro especial, pelo oficial do Registro de Imóveis do domicílio dos cônjuges.

\section{CAPÍTULO III}

\section{Do Regime de Comunhão Parcial}

Art. 1.658. No regime de comunhão parcial, comunicam-se os bens que sobrevierem ao casal, na constância do casamento, com as exceções dos artigos seguintes.

Art. 1.659. Excluem-se da comunhão:

I - os bens que cada cônjuge possuir ao casar, e os que lhe sobrevierem, na constância do casamento, por doação ou sucessão, e os sub-rogados em seu lugar;

II - os bens adquiridos com valores exclusivamente pertencentes a um dos cônjuges em subrogação dos bens particulares;

III - as obrigações anteriores ao casamento;

IV - as obrigações provenientes de atos ilícitos, salvo reversão em proveito do casal;

$\mathrm{V}$ - os bens de uso pessoal, os livros e instrumentos de profissão;

VI - os proventos do trabalho pessoal de cada cônjuge;

VII - as pensões, meios-soldos, montepios e outras rendas semelhantes.

Art. 1.660. Entram na comunhão:

I - os bens adquiridos na constância do casamento por título oneroso, ainda que só em nome de um dos cônjuges;

II - os bens adquiridos por fato eventual, com ou sem o concurso de trabalho ou despesa anterior;

III - os bens adquiridos por doação, herança ou legado, em favor de ambos os cônjuges;

IV - as benfeitorias em bens particulares de cada cônjuge;

$\mathrm{V}$ - os frutos dos bens comuns, ou dos particulares de cada cônjuge, percebidos na constância do casamento, ou pendentes ao tempo de cessar a comunhão.

Art. 1.661. São incomunicáveis os bens cuja aquisição tiver por título uma causa anterior ao casamento.

Art. 1.662. No regime da comunhão parcial, presumem-se adquiridos na constância do casamento os bens móveis, quando não se provar que o foram em data anterior.

Art. 1.663. A administração do patrimônio comum compete a qualquer dos cônjuges.

$\S 1^{\underline{0}}$ As dívidas contraídas no exercício da administração obrigam os bens comuns e particulares do cônjuge que os administra, e os do outro na razão do proveito que houver auferido.

$\S 2^{\underline{0}}$ A anuência de ambos os cônjuges é necessária para os atos, a título gratuito, que impliquem cessão do uso ou gozo dos bens comuns. 
$\S 3^{\circ}$ Em caso de malversação dos bens, o juiz poderá atribuir a administração a apenas um dos cônjuges.

Art. 1.664. Os bens da comunhão respondem pelas obrigações contraídas pelo marido ou pela mulher para atender aos encargos da família, às despesas de administração e às decorrentes de imposição legal.

Art. 1.665. A administração e a disposição dos bens constitutivos do patrimônio particular competem ao cônjuge proprietário, salvo convenção diversa em pacto antenupcial.

Art. 1.666. As dívidas, contraídas por qualquer dos cônjuges na administração de seus bens particulares e em benefício destes, não obrigam os bens comuns.

\section{CAPÍTULO IV}

\section{Do Regime de Comunhão Universal}

Art. 1.667. O regime de comunhão universal importa a comunicação de todos os bens presentes e futuros dos cônjuges e suas dívidas passivas, com as exceções do artigo seguinte.

Art. 1.668. São excluídos da comunhão:

I - os bens doados ou herdados com a cláusula de incomunicabilidade e os sub-rogados em seu lugar;

II - os bens gravados de fideicomisso e o direito do herdeiro fideicomissário, antes de realizada a condição suspensiva;

III - as dívidas anteriores ao casamento, salvo se provierem de despesas com seus aprestos, ou reverterem em proveito comum;

IV - as doações antenupciais feitas por um dos cônjuges ao outro com a cláusula de incomunicabilidade;

$\mathrm{V}$ - Os bens referidos nos incisos V a VII do art. 1.659.

Art. 1.669. A incomunicabilidade dos bens enumerados no artigo antecedente não se estende aos frutos, quando se percebam ou vençam durante o casamento.

Art. 1.670. Aplica-se ao regime da comunhão universal o disposto no Capítulo antecedente, quanto à administração dos bens.

Art. 1.671. Extinta a comunhão, e efetuada a divisão do ativo e do passivo, cessará a responsabilidade de cada um dos cônjuges para com os credores do outro.

\section{CAPÍTULO V}

\section{Do Regime de Participação Final nos Aquestos}

Art. 1.672. No regime de participação final nos aqüestos, cada cônjuge possui patrimônio próprio, consoante disposto no artigo seguinte, e lhe cabe, à época da dissolução da sociedade conjugal, direito à metade dos bens adquiridos pelo casal, a título oneroso, na constância do casamento.

Art. 1.673. Integram o patrimônio próprio os bens que cada cônjuge possuía ao casar e os por ele adquiridos, a qualquer título, na constância do casamento.

Parágrafo único. A administração desses bens é exclusiva de cada cônjuge, que os poderá livremente alienar, se forem móveis. 
Art. 1.674. Sobrevindo a dissolução da sociedade conjugal, apurar-se-á o montante dos aqüestos, excluindo-se da soma dos patrimônios próprios:

I - os bens anteriores ao casamento e os que em seu lugar se sub-rogaram;

II - os que sobrevieram a cada cônjuge por sucessão ou liberalidade;

III - as dívidas relativas a esses bens.

Parágrafo único. Salvo prova em contrário, presumem-se adquiridos durante o casamento os bens móveis.

Art. 1.675. Ao determinar-se o montante dos aqüestos, computar-se-á o valor das doações feitas por um dos cônjuges, sem a necessária autorização do outro; nesse caso, o bem poderá ser reivindicado pelo cônjuge prejudicado ou por seus herdeiros, ou declarado no monte partilhável, por valor equivalente ao da época da dissolução.

Art. 1.676. Incorpora-se ao monte o valor dos bens alienados em detrimento da meação, se não houver preferência do cônjuge lesado, ou de seus herdeiros, de os reivindicar.

Art. 1.677. Pelas dívidas posteriores ao casamento, contraídas por um dos cônjuges, somente este responderá, salvo prova de terem revertido, parcial ou totalmente, em benefício do outro.

Art. 1.678. Se um dos cônjuges solveu uma dívida do outro com bens do seu patrimônio, o valor do pagamento deve ser atualizado e imputado, na data da dissolução, à meação do outro cônjuge.

Art. 1.679. No caso de bens adquiridos pelo trabalho conjunto, terá cada um dos cônjuges uma quota igual no condomínio ou no crédito por aquele modo estabelecido.

Art. 1.680. As coisas móveis, em face de terceiros, presumem-se do domínio do cônjuge devedor, salvo se o bem for de uso pessoal do outro.

Art. 1.681. Os bens imóveis são de propriedade do cônjuge cujo nome constar no registro.

Parágrafo único. Impugnada a titularidade, caberá ao cônjuge proprietário provar a aquisição regular dos bens.

Art. 1.682. O direito à meação não é renunciável, cessível ou penhorável na vigência do regime matrimonial.

Art. 1.683. Na dissolução do regime de bens por separação judicial ou por divórcio, verificar-seá o montante dos aqüestos à data em que cessou a convivência.

Art. 1.684. Se não for possível nem conveniente a divisão de todos os bens em natureza, calcular-se-á o valor de alguns ou de todos para reposição em dinheiro ao cônjuge nãoproprietário.

Parágrafo único. Não se podendo realizar a reposição em dinheiro, serão avaliados e, mediante autorização judicial, alienados tantos bens quantos bastarem.

Art. 1.685. Na dissolução da sociedade conjugal por morte, verificar-se-á a meação do cônjuge sobrevivente de conformidade com os artigos antecedentes, deferindo-se a herança aos herdeiros na forma estabelecida neste Código.

Art. 1.686. As dívidas de um dos cônjuges, quando superiores à sua meação, não obrigam ao outro, ou a seus herdeiros.

\section{CAPÍTULO VI}




\section{Do Regime de Separação de Bens}

Art. 1.687. Estipulada a separação de bens, estes permanecerão sob a administração exclusiva de cada um dos cônjuges, que os poderá livremente alienar ou gravar de ônus real.

Art. 1.688. Ambos os cônjuges são obrigados a contribuir para as despesas do casal na proporção dos rendimentos de seu trabalho e de seus bens, salvo estipulação em contrário no pacto antenupcial.

\section{TÍTULO III}

\section{DA UNIÃO ESTÁVEL}

Art. 1.723. É reconhecida como entidade familiar a união estável entre o homem e a mulher, configurada na convivência pública, contínua e duradoura e estabelecida com o objetivo de constituição de família.

$\S 1^{\circ}$ A união estável não se constituirá se ocorrerem os impedimentos do art. 1.521; não se aplicando a incidência do inciso VI no caso de a pessoa casada se achar separada de fato ou judicialmente.

$\S 2^{\underline{o}}$ As causas suspensivas do art. 1.523 não impedirão a caracterização da união estável.

Art. 1.724. As relações pessoais entre os companheiros obedecerão aos deveres de lealdade, respeito e assistência, e de guarda, sustento e educação dos filhos.

Art. 1.725. Na união estável, salvo contrato escrito entre os companheiros, aplica-se às relações patrimoniais, no que couber, o regime da comunhão parcial de bens.

Art. 1.726. A união estável poderá converter-se em casamento, mediante pedido dos companheiros ao juiz e assento no Registro Civil.

Art. 1.727. As relações não eventuais entre o homem e a mulher, impedidos de casar, constituem concubinato. 
ANEXO III - CÓDIGO CIVIL DE 1916

CÓDIGO CIVIL DE 1916 - PARTE ESPECIAL

LIVRO I - DO DIREITO DE FAMÍLIA

TÍTULO I - DO CASAMENTO

CAPÍTULO I - DAS FORMALIDADES PRELIMINARES

Art. 180. A habilitação para casamento faz-se perante o oficial do registro civil, apresentando-se os seguintes documentos:

I - certidão de idade ou prova equivalente;

II - declaração do estado, do domicílio e da residência atual dos contraentes e de seus pais, se forem conhecidos;

III - autorização das pessoas sob cuja dependência legal estiverem, ou ato judicial que a supra (arts. 183, XI, 188 e 196);

IV - declaração de duas testemunhas maiores, parentes, ou estranhos, que atestem conhecê-los e afirmem não existir impedimento, que os iniba de casar;

$\mathrm{V}$ - certidão de óbito do cônjuge falecido, da anulação do casamento anterior ou do registro da sentença de divórcio. (Redação da Lei $n^{o}$ 6.515, de 26.12.1977)

Parágrafo único. Se algum dos contraentes houver residido a maior parte do último ano em outro Estado, apresentará prova de que o deixou sem impedimento para casar, ou de que cessou o existente.

Art. 181. À vista desses documentos apresentados pelos pretendentes, ou seus procuradores, o oficial do registro lavrará os proclamas de casamento, mediante edital, que se afixará durante 15 (quinze) dias, em lugar ostensivo do edifício, onde se celebrarem os casamentos, e se publicará pela imprensa, onde a houver (art. 182, parágrafo único).

$\S 1^{\underline{0}}$ Se, decorrido esse prazo, não aparecer quem imponha impedimento, nem lhe constar algum dos que de ofício lhe cumpre declarar, o oficial do registro certificará aos pretendentes que estão habilitados para casar dentro nos 3 (três) meses imediatos (art. 192).

$\S 2^{\circ}$ Se os nubentes residirem em diversas circunscrições do Registro Civil, em uma e em outra se publicarão os editais.

Art. 182. O registro dos editais far-se-á no cartório do oficial, que os houver publicado, dando-se deles certidão a quem pedir.

Parágrafo único. A autoridade competente, havendo urgência, poderá dispensar-lhes a publicação, desde que se lhe apresentem os documentos exigidos no art. 180.

\section{CAPÍTULO II DOS IMPEDIMENTOS}

Art. 183. Não podem casar (arts. 207 e 209): 
I - os ascendentes com os descendentes, seja o parentesco legítimo ou ilegítimo, natural ou civil;

II - os afins em linha reta, seja o vínculo legítimo ou ilegítimo;

III - o adotante com o cônjuge do adotado e o adotado com o cônjuge do adotante (art. 376);

IV - os irmãos, legítimos ou ilegítimos, germanos ou não, e os colaterais, legítimos ou ilegítimos, até o terceiro grau inclusive;

V - o adotado com o filho superveniente ao pai ou à mãe adotiva (art. 376);

VI - as pessoas casadas (art. 203);

VII - o cônjuge adúltero com o seu co-réu, por tal condenado;

VIII - o cônjuge sobrevivente com o condenado como delinqüente no homicídio, ou tentativa de homicídio, contra o seu consorte;

IX - as pessoas por qualquer motivo coactas e as incapazes de consentir; (Redação do Dec. Legislativo $n^{o} 3.725$, de 15.1.1919)

$\mathrm{X}$ - o raptor com a raptada, enquanto esta não se ache fora do seu poder e em lugar seguro;

XV - o tutor ou curador e os seus descendentes, ascendentes, irmãos, cunhados ou sobrinhos, com a pessoa tutelada ou curatelada, enquanto não cessar a tutela ou curatela, e não estiverem saldadas as respectivas contas, salvo permissão paterna ou materna manifestada em escrito autêntico ou em testamento;

XVI - o juiz, ou escrivão e seus descendentes, ascendentes, irmãos, cunhados ou sobrinhos, com órfão ou viúva, da circunscrição territorial onde um ou outro tiver exercício, salvo licença especial da autoridade judiciária superior.

Art. 184. A afinidade resultante de filiação espúria poderá provar-se por confissão espontânea dos ascendentes da pessoa impedida, os quais, se o quiserem, terão o direito de fazê-la em segredo de justiça.

Parágrafo único. A resultante da filiação natural poderá ser também provada por confissão espontânea dos ascendentes, se da filiação não existir a prova prescrita no art. 357.

Art. 185. Para o casamento dos menores de 21 (vinte e um) anos, sendo filhos legítimos, é mister o consentimento de ambos os pais.

Art. 186. Discordando eles entre si, prevalecerá a vontade paterna, ou sendo o casal separado, divorciado ou tiver sido o seu casamento anulado, a vontade do cônjuge, com quem estiverem os filhos. (Redação da Lei $n^{\circ} 6.515$, de 26.12.1977)

Parágrafo único. Sendo, porém, ilegítimos os filhos, bastará o consentimento do que houver reconhecido o menor, ou, se este não for reconhecido, o consentimento

materno.

Art. 187. Até a celebração do matrimônio podem os pais, tutores e curadores 
retratar o seu consentimento. (Redação do Dec. Legislativo $n^{o} 3.725$, de 15.1.1919)

Art. 188. A denegação do consentimento, quando injusta, pode ser suprida pelo juiz, com recurso para a instância superior.

\section{CAPÍTULO III DA OPOSIÇÃO DOS IMPEDIMENTOS}

Art. 189. Os impedimentos do art. 183, I a XII, podem ser opostos:

I - pelo oficial do registro civil (art. 227, III);

II - por quem presidir à celebração do casamento;

III - por qualquer pessoa maior, que, sob sua assinatura, apresente declaração escrita, instruída com as provas do fato que alegar.

Parágrafo único. Se não puder instruir a oposição com as provas, precisará o oponente o lugar, onde existam, ou nomeará, pelo menos, duas testemunhas, residentes no Município, que atestem o impedimento.

Art. 190. Os outros impedimentos só poderão ser opostos:

I - pelos parentes, em linha reta, de um dos nubentes, sejam consangüíneos ou afins;

II - pelos colaterais, em segundo grau, sejam consangüíneos ou afins.

Art. 191. O oficial do registro civil dará aos nubentes, ou seus representantes, nota do impedimento oposto, indicando os fundamentos, as provas, e, se o impedimento não se opôs ex officio, o nome do oponente.

Parágrafo único. Fica salvo aos nubentes fazer a prova contrária ao impedimento e promover as ações civis e criminais contra o oponente de máfé.(Redação do Dec. Legislativo $n^{o}$ 3.725, de 15.1.1919)

\section{CAPÍTULO IV}

\section{DA CELEBRAÇÃO DO CASAMENTO}

Art. 192. Celebrar-se-á o casamento no dia, hora e lugar previamente designados pela autoridade que houver de presidir ao ato, mediante petição dos contraentes, que se mostrem habilitados com a certidão do art. $181, \S 1^{\circ}$.

Art. 193. A solenidade celebrar-se-á na casa das audiências, com toda a publicidade, a portas abertas, presentes, pelo menos, duas testemunhas, parentes ou não dos contraentes, ou, em caso de força maior, querendo as partes, e consentindo o juiz, noutro edifício, público, ou particular.

Parágrafo único. Quando o casamento for em casa particular, ficará esta de portas abertas durante o ato, e, se algum dos contraentes não souber escrever, serão quatro as testemunhas.

Art. 194. Presentes os contraentes, em pessoa ou por procurador especial, juntamente com as testemunhas e o oficial do registro, o presidente do ato, ouvida aos nubentes afirmação de que persistem no propósito de casar por livre e espontânea vontade, declarará efetuado o casamento, nestes termos: 
"De acordo com a vontade que ambos acabais de afirmar perante mim, de vos receberdes por marido e mulher, eu, em nome da lei, vos declaro casados".

Art. 195. Do matrimônio, logo depois de celebrado, se lavrará o assento no livro de registro (art. 202).

No assento, assinado pelo presidente do ato, os cônjuges, as testemunhas e o oficial do registro, serão exarados:

I - os nomes, prenomes, datas de nascimento, profissão, domicílio e residência atual dos cônjuges;

II - os nomes, prenomes, datas de nascimento ou de morte, domicílio e residência atual dos pais;

III - os nomes e prenomes do cônjuge precedente e a data da dissolução do casamento anterior;

IV - a data da publicação dos proclamas e da celebração do casamento; (Redação do Dec. Legislativo $n^{o}$ 3.725, de 15.1.1919)

V - a relação dos documentos apresentados ao oficial do registro (art. 180); (Redação do Dec. Legislativo $n^{o} 3.725$, de 15.1.1919)

VI - os nomes, prenomes, profissão, domicílio e residência atual das testemunhas;

VII - o regime do casamento, com a declaração da data e do cartório em cujas notas foi passada a escritura antenupcial, quando o regime não for o de comunhão parcial, ou o legal estabelecido no Título III deste Livro, para outros casamentos. (Redação da Lei $n^{\circ} 6.515$, de 26.12.1977)

Art. 196. O instrumento da autorização para casar transcrever-se-á integralmente na escritura antenupcial.

Art. 197. A celebração do casamento será imediatamente suspensa, se algum dos contraentes:

I - recusar a solene afirmação da sua vontade; II - declarar que esta não é livre e espontânea; III - manifestar-se arrependido.

Parágrafo único. O nubente que, por algum destes fatos, der causa à suspensão do ato, não será admitido a retratar-se no mesmo dia.

Art. 198. No caso de moléstia grave de um dos nubentes, o presidente do ato irá celebrá-lo na casa do impedido e, sendo urgente, ainda à noite, perante quatro testemunhas, que saibam ler e escrever.

$\S 1^{\circ}$ A falta ou impedimento da autoridade competente para presidir ao casamento suprir-se-á por qualquer dos seus substitutos legais, e a do oficial do registro civil por outro ad hoc, nomeado pelo presidente do ato.

$\S 2^{\circ}$ O termo avulso, que o oficial ad hoc lavrar, será levado ao registro no mais breve prazo possível. 
Art. 199. O oficial do registro, mediante despacho da autoridade competente, à vista dos documentos exigidos no art. 180 e independentemente do edital de proclamas (art. 181), dará a certidão ordenada no art. 181, § $1^{\circ}$ :

I - quando ocorrer motivo urgente que justifique a imediata celebração do casamento;

II - quando algum dos contraentes estiver em eminente risco de vida.

Parágrafo único. Neste caso, não obtendo os contraentes a presença da autoridade, a quem incumba presidir ao ato, nem a de seu substituto, poderão celebrá-lo em presença de seis testemunhas, que com os nubentes não tenham parentesco em linha reta, ou, na colateral, em segundo grau.

Art. 200. Essas testemunhas comparecerão dentro em 5 (cinco) dias ante a autoridade judicial mais próxima, pedindo que se lhes tomem por termo as seguintes declarações:

I - que foram convocadas por parte do enfermo;

II - que este parecia em perigo de vida, mas em seu juízo;

III - que em sua presença, declararam os contraentes livre e espontaneamente receber-se por marido e mulher.

$\S 1^{\circ}$ Autuado o pedido e tomadas as declarações, o juiz procederá às diligências necessárias para verificar se os contraentes podiam ter-se habilitado para o casamento, na forma ordinária, ouvidos os interessados, que o requererem, dentro em 15 (quinze) dias.

$\S 2^{\circ}$ Verificada a idoneidade dos cônjuges para o casamento, assim o decidirá a autoridade competente, com recurso voluntário às partes.

$\S 3^{\circ}$ Se da decisão não se tiver recorrido, ou se ela passar em julgado, apesar dos recursos interpostos, o juiz mandará transcrevê-la no livro do registro dos casamentos.

$\S 4^{\circ} \mathrm{O}$ assento assim lavrado retrotrairá os efeitos do casamento, quanto ao estado dos cônjuges, à data da celebração e, quanto aos filhos comuns, à data do nascimento.

$\S 5^{\mathrm{o}}$ Serão dispensadas as formalidades deste e do artigo anterior, se o enfermo convalescer e puder ratificar o casamento em presença da autoridade competente e do oficial do registro.

Art. 201. O casamento pode celebrar-se mediante procuração, que outorgue poderes especiais ao mandatário para receber, em nome do outorgante, o outro contraente.

Parágrafo único. Pode casar por procuração o preso, ou o condenado, quando lhe não permita comparecer em pessoa a autoridade, sob cuja guarda estiver.

\section{CAPÍTULO V DAS PROVAS DO CASAMENTO}

Art. 202. O casamento celebrado no Brasil prova-se pela certidão do registro, feito ao tempo de sua celebração (art. 195). 
Parágrafo único. Justificada a falta ou perda do registro civil, é admissível qualquer outra espécie de prova.

Art. 203. O casamento de pessoas que faleceram na posse do estado de casadas não se pode contestar em prejuízo da prole comum, salvo mediante certidão do registro civil, que prove que já era casada alguma delas, quando contraiu o matrimônio impugnado (art. 183, VI).

Art. 204. O casamento celebrado fora do Brasil prova-se de acordo com a lei do país, onde se celebrou.

Parágrafo único. Se, porém, se contraiu perante agente consular, provar-se-á por certidão do assento no registro do consulado.

Art. 205. Quando a prova de celebração legal do casamento resultar de processo judicial, a inscrição da sentença no livro do registro civil produzira, assim no que toca aos cônjuges, como no que respeita aos filhos, todos os efeitos civis desde a data do casamento. (Redação do Dec. Legislativo $n^{o}$ 3.725, de 15.1.1919)

Art. 206. Na dúvida entre as provas pró e contra, julgar-se-á pelo casamento, se os cônjuges, cujo matrimônio se impugna, viverem ou tiverem vívido na posse do estado de casados.

\section{CAPÍTULO VI \\ DO CASAMENTO NULO E ANULÁVEL}

Art. 207. É nulo e de nenhum efeito, quanto aos contraentes e aos filhos, o casamento contraído com infração de qualquer dos ns. I a VIII do art. 183.

Art. 208. É também nulo o casamento contraído perante autoridade incompetente (arts. 192, 194, 195 e 198). Mas esta nulidade se considerará sanada, se não se alegar dentro em 2 (dois) anos da celebração.

Parágrafo único. Antes de vencido esse prazo, a declaração da nulidade poderá ser requerida:

I - por qualquer interessado;

II - pelo Ministério Público, salvo se já houver falecido algum dos cônjuges.

Art. 209. É anulável o casamento contraído com infração de qualquer dos ns. IX a XII do art. 183.

Art. 210. A anulação do casamento contraído pelo coacto ou pelo incapaz de consentir, só pode ser promovida:

I - pelo

próprio

coacto;

II - pelo incapaz;

III - por seus representantes legais. 
Art. 211. O que contraiu casamento, enquanto incapaz, pode ratificá-lo, quando adquirir a necessária capacidade, e esta ratificação retrotrairá os seus efeitos à data da celebração.

Art. 212. A anulação do casamento contraído com infração do $n^{\circ} \mathrm{XI}$ do art. 183 só pode ser requerida pelas pessoas que tinham o direito de consentir e não assistiram ao ato.

Art. 213. A anulação do casamento da menor de 16 (dezesseis) anos ou do menor de 18 (dezoito) será requerida:
I - pelo
próprio
cônjuge
menor;
II - pelos
seus
representantes
legais;
III - pelas pessoas designadas no art. 190, naquela mesma ordem.

Art. 214. Podem, entretanto, casar-se os referidos menores para evitar a imposição ou o cumprimento da pena criminal.

Parágrafo único. Em tal caso o juiz poderá ordenar a separação de corpos, até que os cônjuges alcance a idade legal.

Art. 215. Por defeito de idade não se anulará o casamento de que resultou gravidez.

Art. 216. Quando requerida por terceiros a anulação do casamento (art. 213, II e III), poderão os cônjuges ratificá-lo, em perfazendo a idade fixada no art. 183, XII, ante o juiz e o oficial do registro civil. A ratificação terá efeito retroativo, subsistindo, entretanto, o regime da separação de bens.

Art. 217. A anulação do casamento não obsta à legitimidade do filho concebido ou havido antes ou na constância dele.

Art. 218. É também anulável o casamento, se houver por parte de um dos nubentes, ao consentir, erro essencial quanto à pessoa do outro.

Art. 219. Considera-se erro essencial sobre a pessoa do outro cônjuge:

I - o que diz respeito à identidade do outro cônjuge, sua honra e boa fama, sendo esse erro tal, que o seu conhecimento ulterior torne insuportável a vida em comum ao cônjuge enganado;

II - a ignorância de crime inafiançável, anterior ao casamento e definitivamente julgado por sentença condenatória;

III - a ignorância, anterior ao casamento, de defeito físico irremediável ou de moléstia grave e transmissível, por contágio ou herança, capaz de por em risco a saúde do outro cônjuge ou de sua descendência;

IV - o defloramento da mulher, ignorado pelo marido.

Art. 220. A anulação do casamento, nos casos do artigo antecedente, só a poderá demandar o cônjuge enganado. (Redação do Dec. Legislativo $n^{\circ} 3.725$, de

15.1.1919)

Art. 221. Embora anulável, ou mesmo nulo, se contraído de boa-fé por ambos os cônjuges, o casamento, em relação a estes como aos filhos, produz todos os efeitos civis até o dia da sentença anulatória.(Redação do Dec. Legislativo $n^{o}$ 3.725, de 15.1.1919) 
Parágrafo único. Se um dos cônjuges estava de boa-fé, ao celebrar o casamento, os seus efeitos civis só a esse e aos filhos aproveitarão.

Art. 222. A nulidade do casamento processar-se-á por ação ordinária, na qual será nomeado curador que o defenda.

Art. 223. Antes de mover a ação de nulidade do casamento, a de anulação, ou a de desquite, requererá o autor, com documento que a autorize, a separação de corpos, que será concedida pelo juiz com a possível brevidade.

Art. 224. Concedida a separação, a mulher poderá pedir os alimentos provisionais, que lhe serão arbitrados, na forma do art. 400 .

\section{CAPÍTULO VII DISPOSIÇÕES PENAIS}

Art. 225. O viúvo, ou a viúva, com filhos do cônjuge falecido, que se casar antes de fazer inventário do casal e dar partilha aos herdeiros, perderá o direito ao usufruto dos bens dos mesmos filhos.

Art. 226. No casamento com infração do art. 183, XI a XVI, é obrigatório o regime da separação de bens, não podendo o cônjuge infrator fazer doações ao outro.

Parágrafo único. Considera-se culpado o tutor que não puder apresentar em seu favor a escusa da cláusula final do art. 183, XV.

Art. 227. Incorre na multa de cem mil-réis a quinhentos mil-réis, além da responsabilidade penal aplicável ao caso, o oficial do registro:

I - que publicar o edital do art. 181, não sendo solicitado por ambos os contraentes;

II - que der a certidão do art. $181, \S 1^{\circ}$, antes de apresentados os documentos do art. 180, ou pendente a oposição de algum impedimento.

III - que não declarar os impedimentos, cuja oposição se lhe fizer, ou cuja existência, sendo aplicáveis de ofício, lhe constar com certeza (art. 189, I).

Art. 228. Nas mesmas penas incorrerá o juiz:

I - que celebrar o casamento antes de levantados os impedimentos opostos contra algum dos contraentes;

II - que deixar de recebê-los, quando oportunamente opostos, nos termos dos arts. 189 a 191 ;

III - que se abstiver de opô-los, quando lhe constarem, e forem dos que se opõem ex officio (art. 189, II);

IV-que se recusar a presidir ao casamento, sem justa causa.

Parágrafo único. Cabe aos interessados promover a aplicação das penas cominadas nos arts. 225 e 226 . A das deste e do art. 227 será promovida pelo Ministério Público, e poderá sê-lo pelos interessados. (Redação do Dec.

Legislativo $n^{\circ} 3.725$, de 15.1.1919) 


\section{TÍTULO II - DOS EFEITOS JURÍDICOS DO CASAMENTO \\ CAPÍTULO I - DISPOSIÇÕES GERAIS}

Art. 229. Criando a família legítima, o casamento legitima os filhos comuns, antes dele nascidos ou concebidos (arts. 352 a 354).

Art. 230. O regime dos bens entre cônjuges começa a vigorar desde a data do casamento, e é irrevogável.

Art. 231. São deveres de ambos os cônjuges:

I - fidelidade recíproca;

II - vida em comum, no domicílio conjugal (arts. 233, IV, e 234);

III - mútua assistência;

IV - sustento, guarda e educação dos filhos.

Art. 232. Quando o casamento for anulado por culpa de um dos cônjuges, este incorrerá:

I - na perda de todas as vantagens havidas do cônjuge inocente;

II - na obrigação de cumprir as promessas, que lhe fez, no contrato antenupcial (arts. 256 e 312).

\section{CAPÍTULO II}

\section{DOS DIREITOS E DEVERES DO MARIDO}

Art. 233. O marido é o chefe da sociedade conjugal, função que exerce com a colaboração da mulher, no interesse comum do casal e dos filhos (arts. 240, 247

e 251). (Redação da Lei $n^{o}$ 4.121, de 27.8.1962)

Compete-lhe:

I - a representação legal da família;(Redação da Lei $n^{o}$ 4.121, de 27.8.1962)

II - a administração dos bens comuns e dos particulares da mulher que ao marido incumbir administrar, em virtude do regime matrimonial adotado, ou de pacto antenupcial (arts. 178, § 9 $9^{\circ}$ I, c, 274, 289, I e 311);(Redação da Lei $\boldsymbol{n}^{\mathbf{o}}$ 4.121, de 27.8.1962)

III - o direito de fixar o domicílio da família, ressalvada a possibilidade de recorrer a mulher ao juiz, no caso de deliberação que a prejudique;(Redação da Lei $n^{\circ}$ 4.121, de 27.8.1962)

IV - Inciso suprimido pela Lei $n^{\circ} 4.121$, de 27.8.1962:

Texto original: $O$ direito de autorizar a profissão da mulher e a sua residência fora do teto conjugal (arts. 231, II, 242, VII, 243 a 245, II e 247, III)

IV - prover a manutenção da família, guardada as disposições dos arts. 275 e 277. (Inciso V renumerado e alterado pela Lei $n^{\circ} 4.121$, de 27.8.1962)

Art. 234. A obrigação de sustentar a mulher cessa, para o marido, quando ela abandona sem justo motivo a habitação conjugal, e a esta recusa voltar. Neste 
caso, o juiz pode, segundo as circunstâncias, ordenar, em proveito do marido e dos filhos, o seqüestro temporário de parte dos rendimentos particulares da mulher.

Art. 235. O marido não pode, sem consentimento da mulher, qualquer que seja o regime de bens:

I - alienar, hipotecar ou gravar de ônus os bens imóveis ou direitos reais sobre imóveis alheios (art. 178, § 9o, I, a, 237, 276 e 293);(Redação da Lei n 4.121, de 27.8.1962)

II - pleitear, como autor ou réu, acerca desses bens e direitos;

III - prestar fiança (arts. 178, § 9, I, b, e 263, X);

IV - fazer doação, não sendo remuneratória ou de pequeno valor, com os bens ou rendimentos comuns (art. 178, § 9º $, \mathrm{I}, \mathrm{b}$ ).

Art. 236. Valerão, porém, os dotes ou doações nupciais feitas às filhas e as doações feitas aos filhos por ocasião de se casarem, ou estabelecerem economia separada (art. 313).

Art. 237. Cabe ao juiz suprir a outorga da mulher, quando esta a denegue sem motivo justo, ou lhe seja impossível dá-la (arts. 235, 238 e 239).

Art. 238. O suprimento judicial da outorga autoriza o ato do marido, mas não obriga os bens próprios da mulher (arts. 247, parágrafo único, 269, 274 e 275)

Art. 239. A anulação dos atos do marido praticados sem outorga da mulher, ou sem suprimento do juiz, só poderá ser demandada por ela, ou seus herdeiros

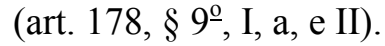

\section{CAPÍTULO III}

\section{DOS DIREITOS E DEVERES DA MULHER}

Art. 240. A mulher, com o casamento, assume a condição de companheira, consorte e colaboradora do marido nos encargos de família, cumprindo-lhe velar pela direção material e moral desta. (Redação dada pela Lei $n^{\circ} 6.515$, de 26.12.1977)

Parágrafo único. A mulher poderá acrescer aos seus os apelidos do marido. (Parágrafo acrescentado pela Lei $n^{\circ} 6.515$, de 26.12.1977)

Art. 241. Se o regime de bens não for o da comunhão universal, o marido recobrará da mulher as despesas, que com a defesa dos bens e direitos particulares desta houver feito.

Art. 242. A mulher não pode, sem autorização do marido (art. 251): (Redação $\begin{array}{llllll}\text { dada pela Lei } & n^{o} & \text { 4.121, } & \text { de } & \text { 27.8.1962) }\end{array}$ I - praticar os atos que este não poderia sem o consentimento da mulher (art. 235); (Redação dada pela Lei $n^{o}$ 4.121, de 27.8.1962)

II - alienar ou gravar de ônus real os imóveis de seu domínio particular, qualquer que seja o regime dos bens (arts. 263, II, III e VIII, 269, 275 e 310); (Redação dada pela Lei $n^{o}$ 4.121, de 27.8.1962) 
III - alienar os seus direitos reais sobre imóveis de outrem; (Redação dada pela

Lei $n^{o}$ 4.121, de 27.8.1962)

IV - suprimido pela Lei $n^{\circ} 4.121$, de 27.8.1962:

Texto original: Aceitar ou repudiar herança ou legado.

V - suprimido pela Lei $n^{\circ}$ 4.121, de 27.8.1962:

Texto original: Aceitar tutela, curatela ou outro munus público.

VI - suprimido pela Lei $n^{\circ} 4.121$, de 27.8.1962:

Texto original: Litigar em juízo civil ou comercial, a não ser nos casos indicados no arts. 248 e 251.

VII - suprimido pela Lei $n^{o}$ 4.121, de 27.8.1962:

Texto original: Exercer a profissão (art. 233, IV)

IV - contrair obrigações que possam importar em alheação de bens do casal.

(Inciso VIII renumerado e alterado pela Lei $n^{\circ} 4.121$, de 27.8.1962)

IX - acrescentado pelo Decreto do Poder Legislativo $n^{\circ}$ 3.725, de 15.1.1919 e suprimido pela Lei $n^{o}$ 4.121, de 27.8.1962:

Texto original: Aceitar mandato (art. 1.299)

Art. 243. A autorização do marido pode ser geral ou especial, mas deve constar de instrumento público ou particular previamente autenticado.

Parágrafo único. suprimido pelo Decreto do Poder Legislativo $n^{o} 3.725$, de 15.1.1919:

Texto original: Considerar-se-á sempre autorizada pelo marido a mulher que ocupar cargo público, ou, por mais de 6 (seis) meses, se entregar a profissão exercida fora do lar conjugal

Art. 244. Esta autorização é revogável a todo o tempo, respeitados os direitos de terceiros e os efeitos necessários dos atos iniciados.

Art. 245. A autorização marital pode suprir-se judicialmente:

I - nos casos do art. 242, I a V;

II - nos casos do art. 242, VII e VIII, se o marido não ministrar os meios de subsistência à mulher e aos filhos.

Parágrafo único. O suprimento judicial da autorização valida os atos da mulher, mas não obriga os bens próprios do marido. (acrescentado pelo Decreto $\begin{array}{lllll}\text { Legislativo } & n^{\circ} & 3.725, & \text { de } & 15.1 .1919)\end{array}$

Art. 246. A mulher que exercer profissão lucrativa, distinta da do marido, terá direito de praticar todos os atos inerentes ao seu exercício e à sua defesa. $\mathrm{O}$ produto do seu trabalho assim auferido, e os bens com ele adquiridos, constituem, salvo estipulação diversa em pacto antenupcial, bens reservados, dos quais poderá dispor livremente com observância, porém, do preceituado na 
parte final do art. 240 e nos ns. II e II do art. 242. (Redação da Lei $n^{\circ} 4.121$, de 27.8.1962)

Parágrafo único. Não responde, o produto do trabalho da mulher, nem os bens a que se refere este artigo, pelas dívidas do marido, exceto as contraídas em benefício da família. (Redação da Lei $n^{\circ}$ 4.121, de 27.8.1962)

Art. 247. Presume-se a mulher autorizada pelo marido:

I - para a compra, ainda a crédito, das coisas necessárias à economia doméstica;

II - para obter, por empréstimo, as quantias que a aquisição dessas coisas possa exigir;

III - para contrair as obrigações concernentes à indústria, ou profissão que exercer com autorização do marido, ou suprimento do juiz.

Parágrafo único. Considerar-se-á sempre autorizada pelo marido a mulher que ocupar cargo público, ou, por mais de 6 (seis) meses, se entregar a profissão exercida fora do lar conjugal. (Redação dada pelo Decreto Legislativo $n^{o}$ 3.725 ,

de

15.1.1919)

Art. 248. A mulher casada pode livremente:(Redação da Lei $n^{o} 4.121$, de 27.8.1962)

I - Exercer o direito que lhe competir sobre as pessoas e os bens dos filhos do leito anterior (art. 393); (Redação dada pela Lei $n^{\circ}$ 4.121, de 27.8.1962)

II - Desobrigar ou reivindicar os imóveis do casal que o marido tenha gravado ou alienado sem sua outorga ou suprimento do juiz (art. 235, I);(Redação da $\begin{array}{lllll}\text { Lei } & n^{o} & \text { 4.121, } & \text { 27.8.1962) }\end{array}$

III - Anular as fianças ou doações feitas pelo marido com infração do disposto nos ns. III e IV do art. 235; (Redação da Lei $n^{o}$ 4.121, de 27.8.1962)

IV - Reivindicar os bens comuns, móveis ou imóveis, doados ou transferidos pelo marido à concubina (art. 1.177). (Redação da Lei $n^{o} 4.121$, de 27.8.1962)

Parágrafo único. Este direito prevalece, esteja ou não a mulher em companhia do marido, e ainda que a doação se dissimule em venda ou outro contrato;

$\begin{array}{lllllll}\text { (Redação } & \text { da } & \text { Lei } & n^{o} & \text { 4.121, } & \text { de } & \text { 27.8.1962) }\end{array}$

V - Dispor dos bens adquiridos na conformidade do número anterior e de quaisquer outros que possua, livres da administração do marido, não sendo imóveis; (Redação da Lei $\quad n^{o}$ 4.121, de 27.8.1962)

VI - Promover os meios assecuratórios e as ações que, em razão do dote ou de outros bens seus sujeitos à administração do marido, contra este lhe competirem; (Redação da Lei $n^{o}$ 4.121, de 27.8.1962) VII - Praticar quaisquer outros atos não vedados por lei; (Redação da Lei $n^{o}$ 4.121, de 27.8.1962)

VIII - Propor a separação judicial e o divórcio. (Inciso suprimido pela Lei $\boldsymbol{n}^{o}$ 4.121, de 27.8.1962 e acrescentado pela Lei $n^{\circ} 6.515$, de 26.12.1977) 
IX - suprimido pela Lei $n^{\circ} 4.121$, de 27.8.1962:

Texto original: Pedir alimentos, quando lhe couberem (art. 224)

X - suprimido pela Lei $n^{o} 4.121$, de 27.8.1962:

Texto original: Fazer testamento ou disposições de ultima vontade.

Art. 249. As ações fundadas nos ns. II, III, IV e VI do artigo antecedente competem à mulher e aos seus herdeiros.

Art. 250. Salvo o caso do ${ }^{\circ}$ IV do art. 248, fica ao terceiro, prejudicado com a sentença favorável à mulher, o direito regressivo contra o marido ou seus herdeiros.

Art. 251. À mulher compete a direção e administração do casal, quando o marido:

I - estiver em lugar remoto, ou não sabido; II - estiver em cárcere por mais de 2 (dois) anos; III - for judicialmente declarado interdito.

Parágrafo único. Nestes casos, cabe à mulher:

I - administrar os bens comuns; II - dispor dos particulares e alienar os móveis comuns e os do marido; III - administrar os do marido;

IV - alienar os imóveis comuns e os do marido mediante autorização especial do juiz.

Art. 252. A falta não suprida pelo juiz, de autorização do marido, quando necessária (art. 242), invalidará o ato da mulher; podendo esta nulidade ser alegada pelo outro cônjuge, até 2 (dois) anos depois de terminada a sociedade conjugal.

Parágrafo único. A ratificação do marido, provada por instrumento público ou particular autenticado, revalida o ato.

Art. 253. Os atos da mulher autorizados pelo marido obrigam todos os bens do casal, se o regime matrimonial for o da comunhão, e somente os particulares dela, se outro for o regime e o marido não assumir conjuntamente a responsabilidade do ato.

Art. 254. Qualquer que seja o regime do casamento, os bens de ambos os cônjuges ficam obrigados igualmente pelos atos que a mulher praticar na $\begin{array}{llll}\text { conformidade } & \text { do art. }\end{array}$

Art. 255. A anulação dos atos de um cônjuge, por falta da outorga indispensável do outro, importa ficar o primeiro obrigado pela importância da vantagem que do ato anulado the haja advindo, a ele, ao consorte ou ao casal.

(Redação do Decreto Legislativo $n^{o} 3.725$, de 15.1.1919)

Parágrafo único. Quando o cônjuge responsável pelo ato anulado não tiver bens particulares, que bastem, o dano aos terceiros de boa-fé se comporá pelos bens comuns, na razão do proveito que lucrar o casal. 


\section{TÍTULO III - DO REGIME DOS BENS ENTRE OS CÔNJUGES CAPÍTULO I - DISPOSIÇÕES GERAIS}

Art. 256. É lícito aos nubentes, antes de celebrado o casamento, estipular, quanto aos seus bens, o que lhes aprouver (arts. 261, 273, 277, 283, 287 e 312).

Parágrafo único. Serão nulas tais convenções:

I - não se fazendo por escritura pública; II - não se lhes seguindo o casamento.

Art. 257. Ter-se-á por não escrita a convenção, ou a cláusula:

I - que prejudique os direitos conjugais, ou os paternos; II - que contravenha disposição absoluta da lei.

Art. 258. Não havendo convenção, ou sendo nula, vigorará, quanto aos bens entre os cônjuges, o regime de comunhão parcial. (Redação da Lei $n^{\circ} 4.121$, de 27.8.1962)

Parágrafo único. É, porém, obrigatório o da separação de bens do casamento:

I - Das pessoas que o celebrarem com infração do estatuído no art. 183, XI a XVI (art. 216);

II - do maior de 60 (sessenta) e da maior de 50 (cinqüenta) anos;

III - do órfão de pai e mãe, ou do menor, nos termos dos arts. 394 e 395, embora case, no termos do art. 183, XI, com o consentimento do tutor; (Redação do Decreto Legislativo $n^{o}$ 3.725, de 15.1.1919)

IV - de todos os que dependerem, para casar, de autorização judicial (arts. 183, XI, 384, III, 426, I, e 453). (Redação dada pelo Decreto Legislativo $n^{\circ} 3.725$, de 15.1.1919)

Art. 259. Embora o regime não seja o da comunhão de bens, prevalecerão, no silêncio do contrato, os princípios dela, quanto à comunicação dos adquiridos na constância do casamento.

Art. 260. O marido, que estiver na posse de bens particulares da mulher, será para com ela e seus herdeiros responsável:

I - como usufrutuário, se o rendimento for comum (arts. 262, 265, 271, V, e 289, II);

II - como procurador, se tiver mandato, expresso ou tácito, para os administrar (art. 311);

III - como depositário, se não for usufrutuário, nem administrador (arts. 269, II, 276 
Art. 261. As convenções antenupciais não terão efeito para com terceiros senão depois de transcritas, em livro especial, pelo oficial do registro de imóveis do domicílio dos cônjuges (art. 256). (Redação do Decreto Legislativo no 3.725, de 15.1.1919)

\section{CAPÍTULO II}

\section{DO REGIME DA COMUNHÃO UNIVERSAL}

Art. 262. O regime da comunhão universal importa a comunicação de todos os bens presentes e futuros dos cônjuges e suas dívidas passivas, com as exceções dos artigos

seguintes.

Art. 263. São excluídos da comunhão:(Redação da Lei $n^{\circ}$ 4.121, de 27.8.1962)

I - as pensões, meios-soldos, montepios, tenças, e outras rendas semelhantes;

$\begin{array}{lllllll}\text { (Redação } & \text { da } & \text { Lei } & n^{o} & \text { 4.121, } & \text { de } & \text { 27.8.1962) }\end{array}$

II - os bens doados ou legados com a cláusula de incomunicabilidade e os subrogados em seu lugar; (Redação da Lei $n^{o}$ 4.121, de 27.8.1962)

III - os bens gravados de fideicomisso e o direito do herdeiro fideicomissário, antes de realizar a condição suspensiva; (Redação da Lei $n^{o} 4.121$, de 27.8.1962)

IV - o dote prometido ou constituído a filhos de outro leito; (Redação da Lei $\left.n^{o} \quad 4.121, \quad d e \quad 27.8 .1962\right)$

$\mathrm{V}$ - o dote prometido ou constituído expressamente por um só dos cônjuges a filho comum; (Redação dada pela Lei $n^{o}$ 4.121, de 27.8.1962)

VI - as obrigações provenientes de atos ilícitos (arts. 1.518 e 1.532); (Redação $\begin{array}{llllll}\text { da } & \text { Lei } & n^{o} & \text { 4.121, } & \text { de } & \text { 27.8.1962) }\end{array}$

VII - as dívidas anteriores ao casamento, salvo se provierem de despesas com seus aprestos, ou reverterem em proveito comum;(Redação da Lei $n^{o} 4.121$, de 27.8.1962)

VIII - as doações antenupciais feitas por um dos cônjuges ao outro com a cláusula de incomunicabilidade (art. 312); (Redação da Lei $n^{o}$ 4.121, de 27.8.1962)

IX - as roupas de uso pessoal, as jóias esponsalícias dadas antes do casamento pelo esposo, os livros e instrumentos de profissão e os retratos da família; (Redação da Lei $\quad n^{o} \quad 4.121$, de 27.8.1962)

X - a fiança prestada pelo marido sem outorga da mulher (arts. 178, § 9, I, b, e 235, III); (Redação dada pela Lei $n^{o}$ 4.121, de 27.8.1962)

XI - os bens da herança necessária a que se impuser a cláusula de incomunicabilidade (art. 1.723); (Inciso acrescentado pelo Decreto Legislativo $n^{o}$ 3.725, de 15.1.1919 e alterado pela Lei $n^{o}$ 4.121, de 27.8.1962)

XII - os bens reservados (art. 246, parágrafo único); (Redação da Lei $n^{\circ} 4.121$, de

27.8.1962) 
XIII - os frutos civis do trabalho ou indústria de cada cônjuge ou de ambos.(Redação da Lei $n^{\circ}$ 4.121, de 27.8.1962)

Art. 264. As dívidas não compreendidas nas duas exceções do $n^{\circ}$ VII, do artigo antecedente, só se poderão pagar durante o casamento, pelos bens que o cônjuge devedor trouxer para o casal.

Art. 265. A incomunicabilidade dos bens enumerados no art. 263 não se lhes estende aos frutos, quando se percebam ou vençam durante o casamento.

Art. 266. Na constância da sociedade conjugal, a propriedade e posse dos bens é comum.

Parágrafo único. A mulher, porém, só os administrará por autorização do marido, ou nos casos do art. 248, V, e art. 251.

Art. 267. Dissolve-se a comunhão:

I - pela morte de um dos cônjuges (art. 315, I);

II - pela sentença que anula o casamento (art. 222);

III - pela separação judicial; (Redação da Lei $n^{o}$ 6.515, de 26.12.1977)

IV - pelo divórcio. (acrescentado pela Lei $n^{\circ} 6.515$, de 26.12.1977)

Art. 268. Extinta a comunhão, e efetuada a divisão do ativo e passivo, cessará a responsabilidade de cada um dos cônjuges para com os credores do outro por dívidas que este houver contraído.

\section{CAPÍTULO III}

\section{DO REGIME DA COMUNHÃO PARCIAL}

Art. 269. No regime de comunhão limitada ou parcial, excluem-se da comunhão: (Redação da Lei $n^{o}$ 4.121, de 27.8.1962)

I - os bens que cada cônjuge possuir ao casar, e os que lhe sobrevierem, na constância do matrimônio por doação ou por sucessão; (Redação da Lei $\boldsymbol{n}^{o}$ 4.121, de 27.8.1962)

II - os adquiridos com valores exclusivamente pertencentes a um dos cônjuges, em sub-rogação dos bens particulares; (Redação da Lei $n^{\circ}$ 4.121, de 27.8.1962)

III - os rendimentos de bens de filhos anteriores ao matrimônio a que tenha direito qualquer dos cônjuges em conseqüência do pátrio poder; (Inciso $\begin{array}{lllllll}\text { acrescentado pela Lei } & n^{o} & 4.121, & \text { de } & \text { 27.8.1962) }\end{array}$

IV - os demais bens que se consideram também excluídos da comunhão universal.(Redação da Lei $n^{\circ}$ 4.121, de 27.8.1962)

Art. 270. Igualmente não se comunicam: 
I - as obrigações anteriores a

II - as provenientes de atos ilícitos.

Art. 271. Entram na comunhão:

I - os bens adquiridos na constância do casamento por título oneroso, ainda que só em nome de um dos cônjuges;

II - os adquiridos por fato eventual, com ou sem concurso de trabalho ou despesa anterior; III - os adquiridos por doação, herança ou legado, em favor de ambos os $\begin{array}{llll}\text { cônjuges } & \text { (art. } & 269, & \text { I); }\end{array}$ IV - as benfeitorias em bens particulares de cada cônjuge;

$\mathrm{V}$ - os frutos dos bens comuns, ou dos particulares de cada cônjuge, percebidos na constância do casamento, ou pendentes ao tempo de cessar a comunhão dos adquiridos;

VI - os frutos civis do trabalho, ou indústria de cada cônjuge, ou de ambos.

Art. 272. São incomunicáveis os bens cuja aquisição tiver por título uma causa anterior

ao

casamento.

Art. 273. No regime da comunhão parcial presumem-se adquiridos na constância do casamento os móveis, quando não se provar com documento autêntico que o foram em data anterior. (Redação da Lei $n^{o} 4.121$, de 27.8.1962)

Art. 274. A administração dos bens do casal compete ao marido, e as dívidas por este contraídas obrigam, não só os bens comuns, senão ainda, em falta destes, os particulares de um e outro cônjuge, na razão do proveito que cada qual houver lucrado.

Art. 275. É aplicável a disposição do artigo antecedente às dívidas contraídas pela mulher, no caso em que os seus atos são autorizados pelo marido, se presumem sê-lo, ou escusam autorização (arts. 242 a 244, 247, 248 e 233, IV).

\section{CAPÍTULO IV DO REGIME DA SEPARAÇÃO}

Art. 276. Quando os contraentes casarem, estipulando separação de bens, permanecerão os de cada cônjuge sob a administração exclusiva dele, que os poderá livremente alienar, se forem móveis (arts. 235, I, 242, II, e 310).

Art. 277. A mulher é obrigada a contribuir para as despesas do casal com os rendimentos de seus bens, na proporção de seu valor, relativamente ao dos marido, salvo estipulação em contrário no contrato antenupcial (arts. 256 e $312)$.

Seção I - Da Constituição do Dote

CAPÍTULO V - DO REGIME DOTAL 
Art. 278. É da essência do regime dotal descreverem-se e estimarem-se cada um de per si, na escritura antenupcial (art. 256), os bens, que constituem o dote, com expressa declaração de que a este regime ficam sujeitos.

Art. 279. O dote pode ser constituído pela própria nubente, por qualquer dos seus antecedentes, ou por outrem.

Parágrafo único. Na celebração do contrato intervirão sempre, em pessoa, ou por procurador, todos os interessados.

Art. 280. O dote pode compreender, no todo, ou em parte, os bens presentes e futuros da mulher.

Parágrafo único. Os bens futuros, porém, só se consideram compreendidos no dote, quando, adquiridos por título gratuito, assim for declarado em cláusula expressa do pacto antenupcial.

Art. 281. Não e lícito aos casados aumentar o dote.

Art. 282. O dote constituído por estranhos durante o matrimônio não altera, quanto aos outros bens, o regime preestabelecido.

Art. 283. É lícito estipular na escritura antenupcial a reversão do dote ao dotador, dissolvida a sociedade conjugal.

Art. 284. Se o dote for prometido pelos pais conjuntamente, sem declaração da parte com que um e outro contribuem, entende-se que cada um se obrigou por metade.

Art. 285. Quando o dote for constituído por qualquer outra pessoa, esta só responderá pela evicção se houver procedido de má-fé, ou se a responsabilidade tiver sido estipulada.

Art. 286. Os frutos do dote são devidos desde a celebração do casamento, e não se estipulou prazo. (Redação do Decreto Legislativo $n^{\circ}$ 3.725, de 15.1.1919)

Art. 287. É permitido estipular no contrato dotal:

I - que a mulher receba, diretamente, para suas despesas particulares, uma determinada parte dos rendimentos dos bens dotais;

II - que, a par dos bens dotais, haja outros, submetidos a regimes diversos.

Parágrafo único. Suprimido pelo Decreto do Poder Legislativo $n^{o} 3.725$, de 15.1.1919:

Texto original: Em falta de expressa declaração quanto ao regime dos bens extra-dotais, prevalecerá o da comunhão.

Art. 288. Aplica-se, no regime dotal, aos adquiridos o disposto neste Título, Capítulo III (arts. 269 a 275).

\section{Seção II}

\section{Dos direito e Obrigações do Marido em Relação aos Bens Dotais}

Art. 289. Na vigência da sociedade conjugal, é direito do marido: 
$\begin{array}{lccc}\text { I - administrar } & \text { os } & \text { bens } & \text { dotais; } \\ \text { II - perceber } & \text { os } & \text { seus } & \text { frutos; } \\ \text { III - usar das ações judiciais a que derem lugar. } & & \end{array}$

Art. 290. Salvo cláusula expressa em contrário, presumir-se-á transferido ao marido o domínio dos bens, sobre que recair o dote, se forem móveis, e não transferidos, se forem imóveis.

Parágrafo único. Suprimido pelo Decreto Legislativo $n^{\circ}$ 3.725, de 15.1.1919:

Texto original: Só mediante cláusula expressa adquirirá domínio o marido sobre os imóveis dotais.

Art. 291. O imóvel adquirido com a importância do dote, quando este consistir em dinheiro, será considerado dotal.

Art. 292. Quando o dote importar alheação, o marido considerar-se-á proprietário, e poderá dispor dos bens dotais, correndo por conta sua os riscos e vantagens que lhes sobrevierem.

Art. 293. Os móveis dotais não podem, sob pena de nulidade, ser onerados, nem alienados, salvo em hasta pública, e por autorização do juiz competente, nos casos seguintes:

I - se de acordo o marido e a mulher quiserem dotar suas filhas comuns; II - em caso de extrema necessidade, por faltarem outros recursos para subsistência da família; III - no caso da primeira parte do $\S 2^{\underline{0}}$ do art. 299; IV - para reparos indispensáveis à conservação de outro imóvel ou imóveis dotais;

$\mathrm{V}$ - quando se acharem indivisos com terceiros, e a divisão for impossível, ou prejudicial;

VI-no caso de desapropriação por utilidade pública; VII - quando estiverem situados em lugar distante do domicílio conjugal, e por isso for manifesta a conveniência de vendê-los.

Parágrafo único. Nos três últimos casos, o preço será aplicado em outros bens, nos quais ficará sub-rogado.

Art. 294. Ficará subsidiariamente responsável o juiz que conceder a alienação fora dos casos e sem as formalidades do artigo antecedente, ou não providenciar na sub-rogação do preço em conformidade com o parágrafo único do mesmo artigo.

Art. 295. A nulidade da alienação pode ser promovida:

I - pela

mulher;

II - pelos seus herdeiros.

Parágrafo único. A reivindicação dos móveis, porém, só será permitida, se o marido não tiver bens com que responda pelo seu valor, ou se a alienação pelo marido e as subseqüentes entre terceiros tiverem sido feitas por título gratuito, ou de má-fé.

Art. 296. O marido fica obrigado por perdas e danos aos terceiros prejudicados com a nulidade, se no contrato de alienação (arts. 293 e 294) não se declarar a natureza dotal dos imóveis. 
Art. 297. Se o marido não tiver imóveis, que se possam hipotecar em garantia do dote, poder-se-á no contrato antenupcial estipular fiança, ou outra caução.

Art. 298. O direito aos imóveis dotais não prescreve durante o matrimônio. Mas prescreve, sob a responsabilidade do marido, o direito aos móveis dotais.

Art. 299. Quanto às dívidas passivas, observar-se-á o seguinte:

$\S 1^{\circ}$ As do marido, contraídas antes ou depois do casamento, não serão pagas senão por seus bens particulares;

$\S 2^{\underline{0}}$ As da mulher, anteriores ao casamento, serão pagas pelos seus bens extradotais, ou, em falta destes, pelos frutos dos bens dotais, pelos móveis dotais e, em último caso, pelos imóveis dotais. As contraídas depois do casamento só poderão ser pagas pelos bens extradotais.

$\S 3^{-}$As contraídas pelo marido e pela mulher conjuntamente poderão ser pagas, ou pelos bens comuns, ou pelos particulares do marido, ou pelos extradotais.

\section{Seção III}

\section{Da Restituição do Dote}

Art. 300. O dote deve ser restituído pelo marido à mulher, ou aos seus herdeiros, dentro no mês que se seguir à dissolução da sociedade conjugal, se não o puder ser imediatamente (art. 178, § $9^{\circ}$, I, c, e II).

Art. 301. O preço dos bens fungíveis, ou não fungíveis, quando legalmente alienados, só pode ser pedido 6 (seis) meses depois da dissolução da sociedade conjugal.

Art. 302. Se os móveis dotais se tiverem consumido por uso ordinário, o marido será obrigado a restituir somente os que restarem, e no estado em que se acharem ao tempo da dissolução da sociedade conjugal.

Art. 303. A mulher pode, em todo o caso, reter os objetos de seu uso, em conformidade com a disposição do art. 263, IX, deduzindo-se o seu valor do que o marido houver de restituir.

Art. 304. Se o dote compreender capitais ou rendas, que tenham sofrido diminuição ou depreciação eventual, sem culpa do marido, este desonerar-se-á da obrigação de restituí-los, entregando os respectivos títulos.

Parágrafo único. Quando, porém, constituído em usufruto, o marido ou seus herdeiros serão obrigados somente a restituir o título respectivo e os frutos percebidos após a dissolução da sociedade conjugal.

Art. 305. Presume-se recebido o dote:

I - se o casamento se tiver prolongado por 5 (cinco) anos depois do prazo estabelecido para sua entrega; II - se o devedor for a mulher.

Parágrafo único. Fica, porém, salvo ao marido o direito de provar que o não recebeu, apesar de o ter exigido. 
Art. 306. Dada a dissolução da sociedade conjugal, os frutos dotais, que correspondam ao ano corrente, serão divididos entre os dois cônjuges, ou entre um e os herdeiros do outro, proporcionalmente à duração do casamento, no decurso do mesmo ano.

Os anos do casamento contam-se na data de sua celebração.

Parágrafo único. Tratando-se de colheitas obtidas em períodos superiores, ou inferiores a 1 (um) ano, a divisão se efetuará proporcionalmente ao tempo de duração da sociedade conjugal, dentro no período da colheita.

Art. 307. O marido tem direito à indenização das benfeitorias necessárias e úteis, segundo o seu valor ao tempo da restituição, e responde pelos danos de que tiver culpa.

Parágrafo único. Este direito e esta obrigação transmitem-se aos seus herdeiros.

\section{Seção IV}

\section{Da Separação do Dote e Sua Administração Pela Mulher}

Art. 308. A mulher pode requerer judicialmente a separação do dote, quando a desordem nos negócios do marido leve a recear que os bens deste não bastem a assegurar os dela; salvo o direito, que aos credores assiste, de se oporem à separação, quando fraudulenta.

Art. 309. Separado o dote, terá por administradora a mulher, mas continuará inalienável, provendo o juiz, quando conceder a separação, a que sejam convertidos em imóveis os valores entregues pelo marido em reposição dos bens dotais.

Parágrafo único. A sentença da separação será averbada no registro de que trata o art. 261, para produzir efeitos em relação a terceiros.

\section{Seção V - Dos Bens Parafernais}

Art. 310. A mulher conserva a propriedade, a administração, o gozo e a livre disposição dos bens parafernais; não podendo, porém, alienar os imóveis (art. 276).

Art. 311. Se o marido, como procurador constituído para administrar os bens parafernais ou particulares da mulher, for dispensado, por cláusula expressa, de prestar-lhe contas, será somente obrigado a restituir os frutos existentes:

I - quando ela pedir contas; II - quando ela lhe revogar o mandato; III - quando dissolvida a sociedade conjugal.

\section{CAPÍTULO VI}

\section{DAS DOAÇÕES ANTENUPCIAIS}

Art. 312. Salvo o caso de separação obrigatória de bens (art. 258, parágrafo único), é livre aos contraentes estipular, na escritura antenupcial, doações recíprocas, ou de um ao outro, contanto que não excedam à metade dos bens do

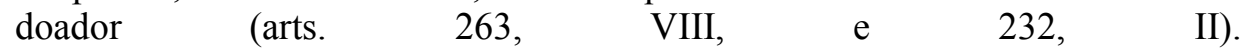
Art. 313. As doações para casamento podem também ser feitas por terceiros, 
no contrato antenupcial, ou em escritura pública anterior ao casamento. (Redação do Decreto Legislativo $n^{\circ} 3.725$, de 15.1.1919)

Art. 314. As doações estipuladas nos contratos antenupciais, para depois da morte do doador, aproveitarão aos filhos do donatário, ainda que este faleça antes daquele.

Parágrafo único. No caso, porém, de sobreviver o doador a todos os filhos do donatário, caducará a doação. 